\title{
WestVirginiaUniversity
}

THE RESEARCH REPOSITORY @ WVU

Graduate Theses, Dissertations, and Problem Reports

2013

\section{A Strategic Study and Economics of Optimum Well Design for the Utica Shale}

Linda N. Anumele

West Virginia University

Follow this and additional works at: https://researchrepository.wvu.edu/etd

\section{Recommended Citation}

Anumele, Linda N., "A Strategic Study and Economics of Optimum Well Design for the Utica Shale" (2013). Graduate Theses, Dissertations, and Problem Reports. 3382.

https://researchrepository.wvu.edu/etd/3382

This Thesis is protected by copyright and/or related rights. It has been brought to you by the The Research Repository @ WVU with permission from the rights-holder(s). You are free to use this Thesis in any way that is permitted by the copyright and related rights legislation that applies to your use. For other uses you must obtain permission from the rights-holder(s) directly, unless additional rights are indicated by a Creative Commons license in the record and/ or on the work itself. This Thesis has been accepted for inclusion in WVU Graduate Theses, Dissertations, and Problem Reports collection by an authorized administrator of The Research Repository @ WVU. For more information, please contact researchrepository@mail.wvu.edu. 
A Strategic Study and Economics of Optimum Well Design for the Utica Shale

\author{
Linda N. Anumele
}

Thesis Submitted to the College of Engineering and Mineral Resources at West Virginia University in partial fulfillment of the requirements for the degree of

\author{
Master of Science \\ In \\ Petroleum and Natural Gas Engineering
}

Ilkin Bilgesu, Ph.D., Chair

Samuel Ameri, M.S.

Daniel E. Della-Giustina, Ph.D.

Department of Petroleum and Natural Gas Engineering

Morgantown, West Virginia

2013

Keywords: Well design, Fracture design, Economic analysis, Utica Shale.

Copyright 2013 Linda N. Anumele 


\title{
ABSTRACT
}

\section{A Strategic Study and Economics of Optimum Well Design for the Utica Shale}

\author{
Linda N. Anumele
}

This research seeks to venture into optimal well and fracture design via reservoir modeling, simulation and economic analysis in an attempt to discover, analyze, interpret and present the best ways of maximizing hydrocarbon (natural gas) production from the Utica shale which is a relatively new reservoir.

Furthermore, comparison of natural gas production in deep and thick Utica shale formation sections is studied for various well and facture designs in conjunction with stimulated reservoir volume analysis and economic analysis in order to achieve an optimal design. The objective of this study is to compare and contrast the gas production from various well and fracture designs in deep and thick Utica formation sections.

This project focuses only on horizontal wells since it has been proven time and again that horizontal wells tend to more viable in shale when compared to vertical well. Therefore, this project focuses only on how to optimize production from the Utica shale by selecting an optimal horizontal well design.

Hence, this thesis work analyzes the effect of fracture half-length, number of fracture treatments and horizontal wellbore lateral lengths on gas production in these shale wells as well as interpretation and presentation of results. Economic evaluations of various well designs are also analyzed, interpreted and presented.

This research presents also results for the Utica shale play productivity via optimal well \& fracture design and detailed economic analysis. 


\section{Acknowledgement}

First of all I am sincerely grateful to Almighty God, for this opportunity and for His immeasurable blessings towards me.

I will like to express my thanks to Dr. Ilkin Bilgesu for his guidance during the preparation of my thesis as well as to Professor Sam Ameri for his contribution and advice during my graduate programme. I would like to thank Dr. Daniel E. Della-Giustina for accepting the invitation to be on my thesis committee. I also thank Ike Eleanya Onuoha and Henry Ubaka for their assistance.

Most importantly, I thank my parents and entire family, especially my mother Noble Stella Ubaka, for helping me with my boys all through my graduate programme. I thank more affectionately my charming boys Jason \& Jayden for their inspiration and for being patient with mum (I love you guys!). They gave me the strength to carry on with my research.

Finally, to the love of my life, my soul mate and precious husband Frank, for his unconditional love, understanding and support; you are truly my best friend, thank you. 


\section{Table of Contents}

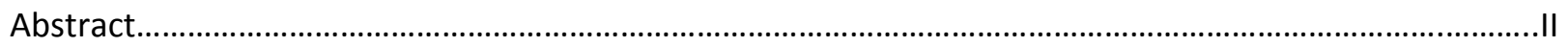

Acknowledgement

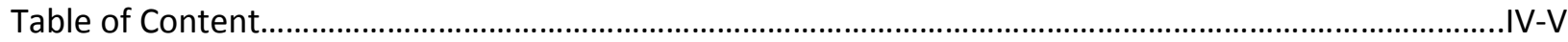

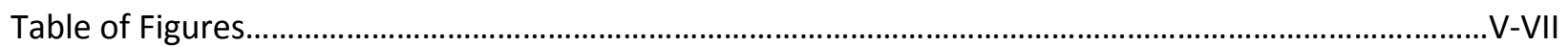

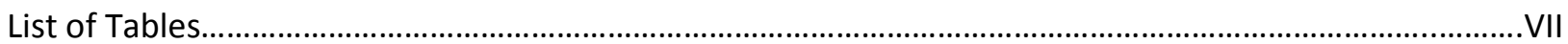

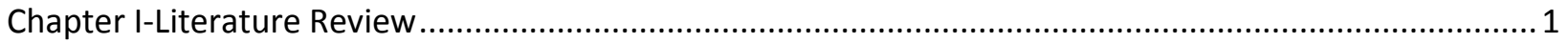

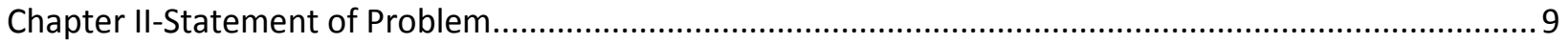

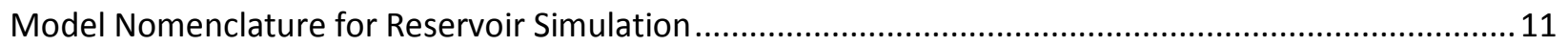

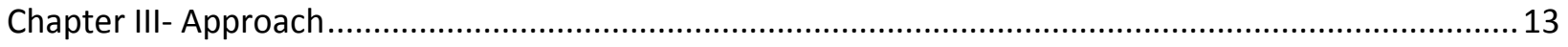

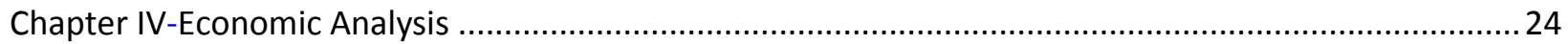

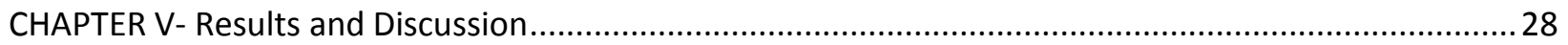

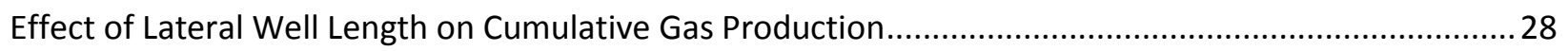

Effect of Number of fracture treatments on $2000 \mathrm{ft}$ lateral horizontal well with $300 \mathrm{ft}$ half length......... 31

Effect of Fracture Half Length on $2000 \mathrm{ft}$ Lateral horizontal well with 3 fracture treatments .................. 33

Effect of Fracture Half Length on $2000 \mathrm{ft}$ Lateral horizontal well with 5 fracture treatments ..................34

Effect of Number of fracture treatments on $4000 \mathrm{ft}$ lateral horizontal well with $300 \mathrm{ft}$ half length .......... 35

Effect of Number of fracture treatments on $4000 \mathrm{ft}$ lateral horizontal well with $600 \mathrm{ft}$ half length ...........36

Effect of Number of fracture treatments on $4000 \mathrm{ft}$ lateral horizontal well with $900 \mathrm{ft}$ half length .......... 37

Effect of Half-length on $4000 \mathrm{ft}$ lateral horizontal well with 3 fracture treatments ............................... 38

Effect of Half-length on $4000 \mathrm{ft}$ lateral horizontal well with 5 fracture treatments ................................39

Effect of Half-length on $4000 \mathrm{ft}$ lateral horizontal well with 9 fracture treatments ............................... 40

Effect of half-length on $6000 \mathrm{ft}$ lateral horizontal well with 3 fracture treatments .............................. 41

Effect of half-length on $6000 \mathrm{ft}$ lateral horizontal well with 5 fracture treatments ................................ 42

Effect of number of frac treatments on $6000 \mathrm{ft}$ lateral horizontal well with $300 \mathrm{ft}$ half length ................ 43

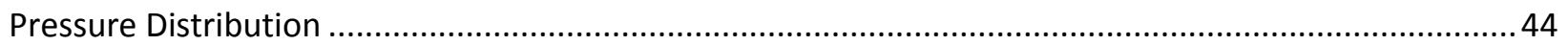

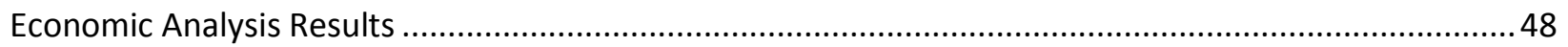

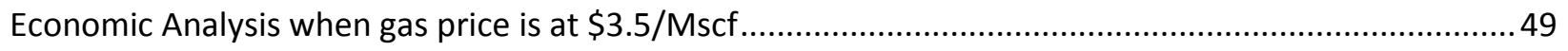

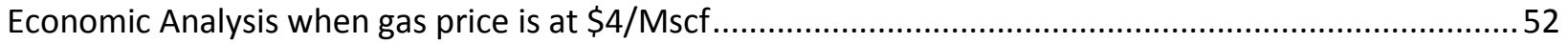

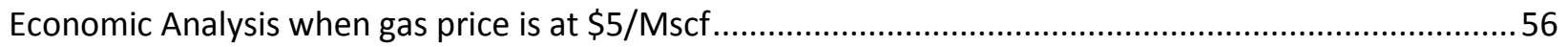

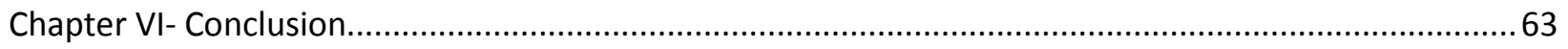


Chapter VII- Recommendation 66

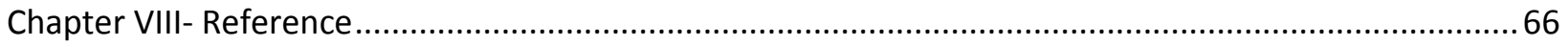

APPENDIX- Pressure Distributions .68

\section{TABLE OF FIGURES}

Figure 1: Shale plays of the U.S. (http://www.naturalgaswatch.org/?p=862) ...................................... 1

Figure 2: Utica shale gas play (http://www.dnr.state.oh.us/tabid/23014/default.aspx) ........................ 4

Figure 3: Utica generalized cross-section Ohio to Pennsylvania

(http://www.dnr.state.oh.us/tabid/23014/default.aspx)

Figure 4: Utica generalized cross-section New York to Pennsylvania

(http://www.dnr.state.oh.us/tabid/23014/default.aspx)

Figure 5: Dark organic rich Utica shale formation in Quebec

(http://www.dnr.state.oh.us/tabid/23014/default.aspx) ..................................................................... 7

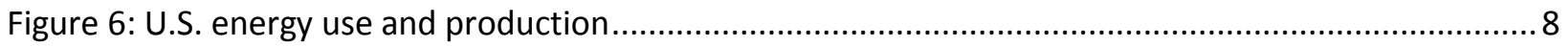

(http://www.dnr.state.oh.us/tabid/23014/default.aspx) .............................................................. 8

Model Nomenclature for Reservoir Simulation .................................................................................. 11

Figure 7: Well design with $2000 \mathrm{ft}$ lateral and 10 fracture treatments of $600 \mathrm{ft}$ half lengths................... 15

Figure 8: Well design with $4000 \mathrm{ft}$ lateral and 20 fracture treatments of $300 \mathrm{ft}$ half lengths....................16

Figure 9: Well design with $6000 \mathrm{ft}$ lateral and 15 fracture treatments of $300 \mathrm{ft}$ half lengths.................. 17

Figure 10: Well design with $4000 \mathrm{ft}$ lateral and 9 fracture treatments of $900 \mathrm{ft}$ half lengths...................18

Figure 11: Well design with $4000 \mathrm{ft}$ lateral and 20 fracture treatments of $300 \mathrm{ft}$ half lengths................. 19

Figure 12: 3D representation of well design with $2000 \mathrm{ft}$ lateral and 3 fracture treatments of $900 \mathrm{ft}$ half

lengths.

Figure 13: 3D representation of well design with $4000 \mathrm{ft}$ lateral and 3 fracture treatments of $900 \mathrm{ft}$ half lengths.

Figure 14: 3D representation of well design with $6000 \mathrm{ft}$ lateral and 3 fracture treatments of $900 \mathrm{ft}$ half lengths

Figure 15: Well design with $6000 \mathrm{ft}$ lateral and 5 fracture treatments of $900 \mathrm{ft}$ half lengths.

Figure 16: Comparison of cumulative gas production from three different lateral wells with no fracture treatments.

Figure 17: Comparison of cumulative gas production from effect of different number of fracture treatments on $2000 \mathrm{ft}$ lateral well with $300 \mathrm{ft}$ half length.

Figure 18: : Comparison of cumulative gas production from effect of different number of fracture treatments on $2000 \mathrm{ft}$ lateral well with $600 \mathrm{ft}$ half length.

Figure 19: Comparison of cumulative gas production from effect of fracture half Length on $2000 \mathrm{ft}$ Lateral well with 3 fracture treatments.

Figure 20: Comparison of cumulative gas production from Effect of Fracture Half Length on $2000 \mathrm{ft}$ Lateral well with 5 fracture treatments. 
Figure 21: Comparison of cumulative gas production from Effect of Number of fracture treatments on $4000 \mathrm{ft}$ lateral well with $300 \mathrm{ft}$ half length

Figure 22: Comparison of cumulative gas production from Effect of Number of fracture treatments on $4000 \mathrm{ft}$ lateral well with $600 \mathrm{ft}$ half length

Figure 23: Comparison of cumulative gas production from Effect of Number of fracture treatments on $4000 \mathrm{ft}$ lateral well with $900 \mathrm{ft}$ half length

Figure 24: Comparison of cumulative gas production from Effect of Fracture Half Length on $4000 \mathrm{ft}$ Lateral well with 3 fracture treatments.

Figure 25: Comparison of cumulative gas production from Effect of Fracture Half Length on $4000 \mathrm{ft}$ Lateral well with 5 fracture treatments.

Figure 26: Comparison of cumulative gas production from Effect of Fracture Half Length on $4000 \mathrm{ft}$ Lateral well with 9 fracture treatments.

Figure 27: Comparison of cumulative gas production from Effect of Fracture Half Length on $6000 \mathrm{ft}$ Lateral well with 3 fracture treatments.

Figure 28: Comparison of cumulative gas production from Effect of Fracture Half Length on $6000 \mathrm{ft}$ Lateral well with 5 fracture treatments.

Figure 29: Comparison of cumulative gas production from Effect of Number of fracture treatments on

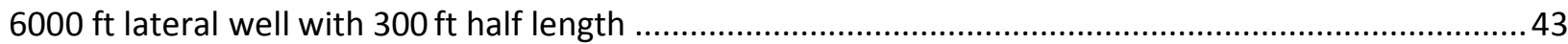

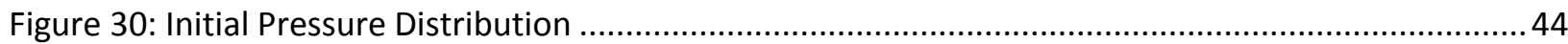

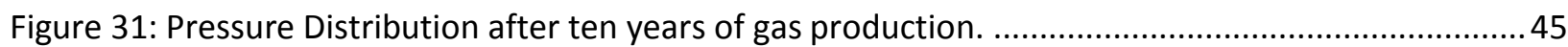

Figure 32: Pressure Distribution after twenty years of gas production. .............................................. 46

Figure 33: Pressure Distribution after 30 years of gas production..........................................................47

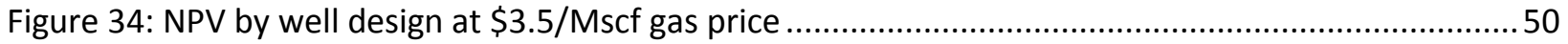

Figure 35: Rate of Return by well design at \$3.5/Mscf gas price ............................................................ 51

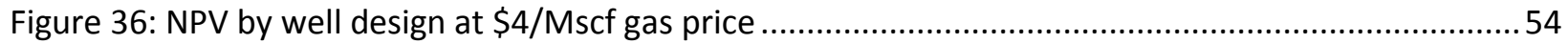

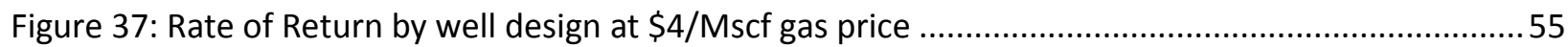

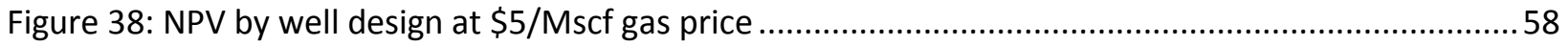

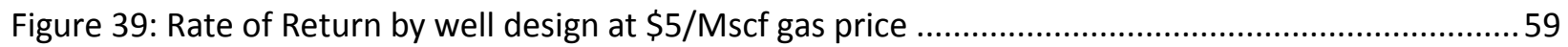

Figure 40: NPV by well design at \$3.5/Mscf, \$4/Mscf and \$5/Mscf gas price ........................................60

Figure 41: Rate of Return by well design at $\$ 3.5 / \mathrm{Mscf}$, $\$ 4 / \mathrm{Mscf}$ and $\$ 5 / \mathrm{Mscf}$ gas price......................... 61

Figure Appendix 1: Initial pressure distribution for well 4000 20Xf300 ...............................................68

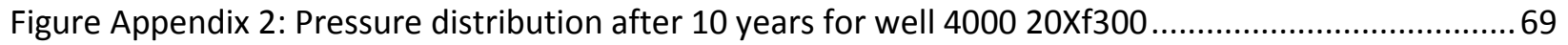

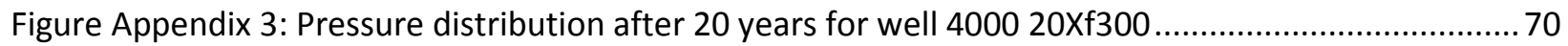

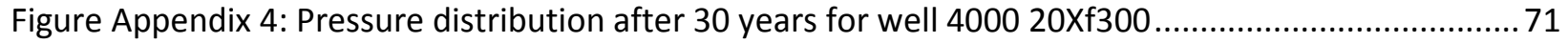

Figure Appendix 5: Initial pressure distribution for well 6000 15Xf300 ................................................ 72

Figure Appendix 6: Pressure distribution after 10 years for well 6000 15Xf300 ....................................73

Figure Appendix 7: Pressure distribution after 20 years for well $600015 \mathrm{Xf300}$.....................................74

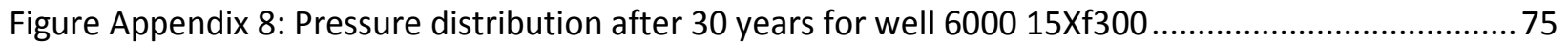

Figure Appendix 9: Initial pressure distribution for well 2000 5Xf900 …................................................ 76

Figure Appendix 10: Pressure distribution after 10 years for well 2000 5Xf900 .................................... 77

Figure Appendix 11: Pressure distribution after 20 years for well 2000 5Xf900 ................................... 78 
Figure Appendix 12: Pressure distribution after 30 years for well $20005 X f 900$

Figure Appendix 13: Initial pressure distribution for well 4000 9Xf600 ................................................. 80

Figure Appendix 14: Pressure distribution after 10 years for well 4000 9xf600 ......................................8 81

Figure Appendix 15: Pressure distribution after 20 years for well 4000 9Xf600 ..................................... 82

Figure Appendix 16: Pressure distribution after 30 years for well 4000 9xf600 ........................................83

\section{LIST OF TABLES}

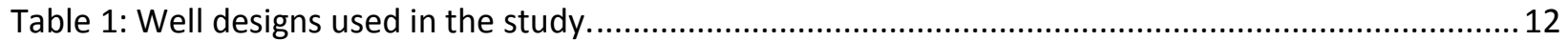

Table 2: Parameters via deterministic approach-History matching. ...................................................... 13

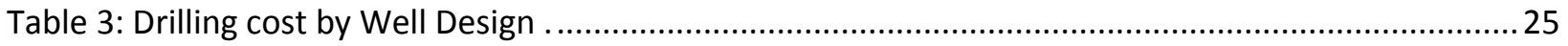

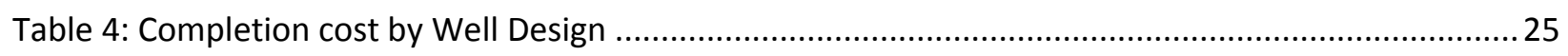

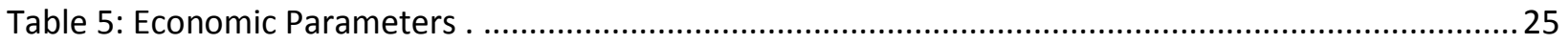

Table 6: NPV analysis for $2000 \mathrm{ft}$ lateral horizontal well with three facture treatments and $600 \mathrm{ft}$ fracture

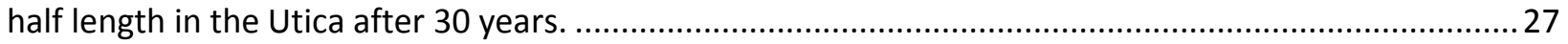

Table 7: Cumulative gas production for different well designs ..................................................................29

Table 8: Summary of Economic Analysis Price of Gas = \$3.5/Mscf .........................................................49

Table 9: Summary of Economic Analysis Price of Gas $=\$ 4 /$ Mscf .............................................................53

Table 10: Summary of Economic Analysis Price of Gas = \$5/Mscf ...........................................................5 57 


\section{Chapter I-Literature Review}

Shale gas is a natural gas formed and trapped within shale formations. Shale gas has become an increasingly important source of natural gas in the United States over the past decade, and interest has spread to potential gas shale's in the rest of the world. In 2000 shale gas provided only $1 \%$ of U.S. natural gas production; by 2010 it was over $20 \%$ and the U.S. government's Energy Information Administration predicts that by 2035, $46 \%$ of the United States' natural gas supply will come from shale gas. Figure 1 shows the shale gas distribution of the U.S. by play.

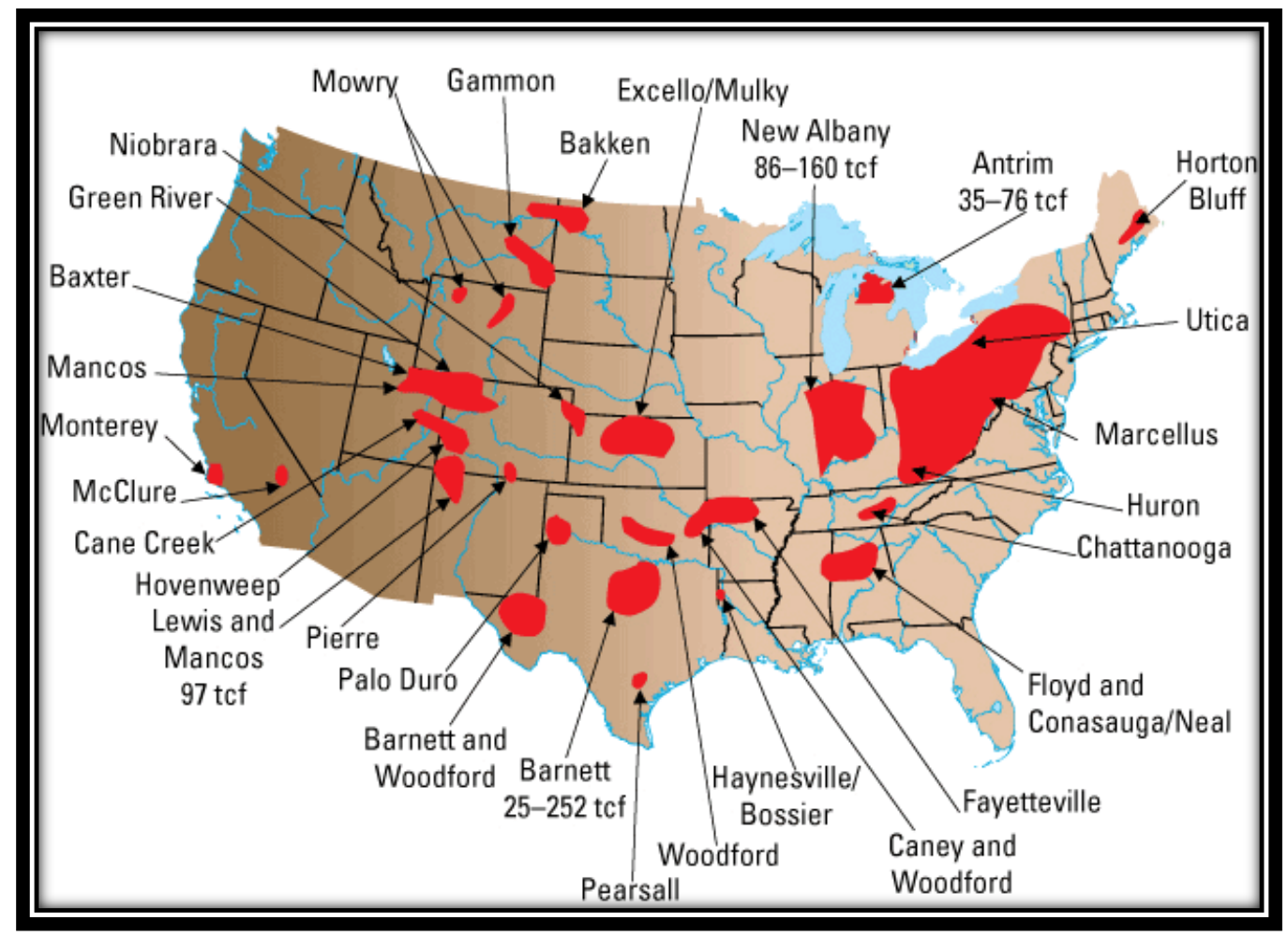

Figure 1: Shale plays of the U.S. (http://www.naturalgaswatch.org/?p=862) 
Some analysts expect that shale gas will greatly expand worldwide energy supply. China is estimated to have the world's largest shale gas reserves. A study by the Baker Institute of Public Policy at Rice University concluded that increased shale gas production in the US and Canada could help prevent Russia and Persian Gulf countries from dictating higher prices for the gas they export to European countries. (Rice Universities, 2009) The Obama administration believes that increased shale gas development will help reduce greenhouse gas emissions through the injection of $\mathrm{CO}_{2}$ into shale formation.

The Utica Shale is a stratigraphic unit of Middle Ordovician age in the Appalachian Basin. It underlies much of the northeastern United States and adjacent parts of Canada. It takes the name from the city of Utica, New York. The Utica Shale lies under most of New York, Pennsylvania, Ohio, and West Virginia and extends under adjacent parts of Ontario and Quebec in Canada and Kentucky, Maryland, Tennessee, and Virginia in the United States. It occurs in outcrops in the state of New York and parts of the island of Montreal consist of Utica shale, which affected construction of parts of the Montreal metro. It has recently become the target of gas and oil exploration in eastern Ohio and Pennsylvania where it is around 8,000 to 14000 feet deep. In 2011 drilling and permits for drilling in the Utica Shale in Ohio reached record highs. It reaches a thickness of up to 1,000 feet and can be as thin as 70 feet towards the margins of the basin. Ohio is currently the center of most exploration and development of the Utica Shale, though many expect exploration and development to spread into Western and Northwestern Pennsylvania. In 2009, Scheper et. al. history matched production from the Utica shale, deriving values for the parameters associated with the Utica shale reservoir production such as fracture permeability, matrix permeability, fracture porosity and matrix porosity. 
The potential source rock portion of the Utica Shale is extensive. In the United States it underlies portions of Kentucky, Maryland, New York, Ohio, Pennsylvania, Tennessee, West Virginia and Virginia. It is also present beneath parts of Lake Ontario, Lake Erie and part of Ontario, Canada. This geographic extent of potential Utica Shale source rock is shown in Figure 2. If the Utica is commercial throughout this extent it will be geographically larger than any natural gas field known today.

Nasar (2011) performed economic analysis on the Coal Bed Methane reservoirs of the Appalachia region of West Virginia and concluded that lateral wells were more economically viable than vertical wells. Also, He Quin (2011) performed parametric and reservoir studies on the sequestration of $\mathrm{CO}_{2}$ into un-mineable coal seams as well as the production of natural gas from the coal seam and concluded that fracture permeability had the most effect on natural gas production and $\mathrm{CO}_{2}$ injection. Finally, Steven (2012) elaborated on the importance of shale gas to the economy of the U.S. and Canada as well as how the shale gas in both countries could neutralize Europe's dependence on Russian energy. Newmann (1988) presented a detailed engineering economic analysis.

Historical studies have also been conducted on the Utica shale. Lash (2008) investigated the fracture and stratigraphy of the Appalachian shale of middle and upper Devonian of which the Utica belongs to. More so, the U.S. Department of Energy is currently conducting research on the "Evaluation of Fracture Systems and Stress Fields within the Marcellus Shale and Utica Shale". More economic evaluation of shale was also conducted by Kaiser and Mark (2011), examining the economic viability and sustainability of the Haynesville shale play. 


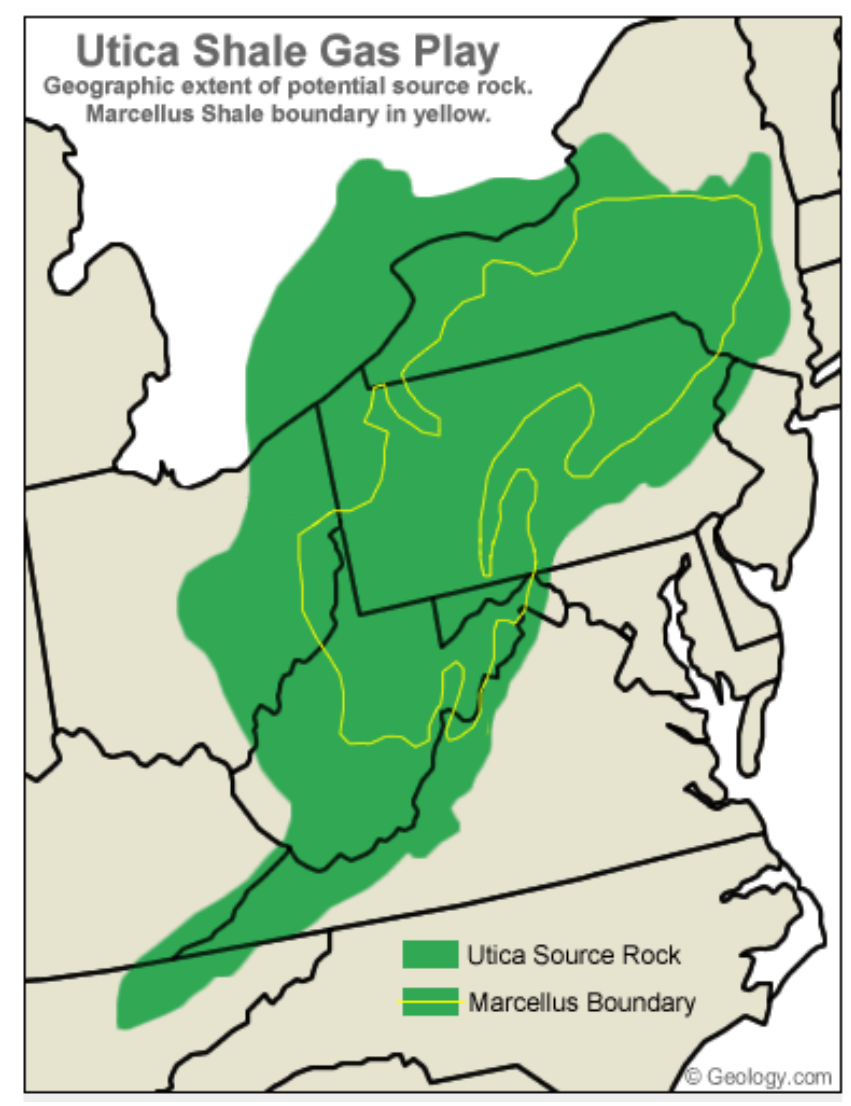

Figure 2: Utica shale gas play

\section{(http://www.dnr.state.oh.us/tabid/23014/default.aspx $)$}

The Utica Shale is thicker than the Marcellus, it is more geographically extensive and it has already proven its ability to support commercial production. This research focuses on the area around the New York/Pennsylvania border where the depth is $6000 \mathrm{ft}$.

Figure 3 below shows a generalized cross-section of the Utica as we move across the border between Ohio and Pennsylvania. 


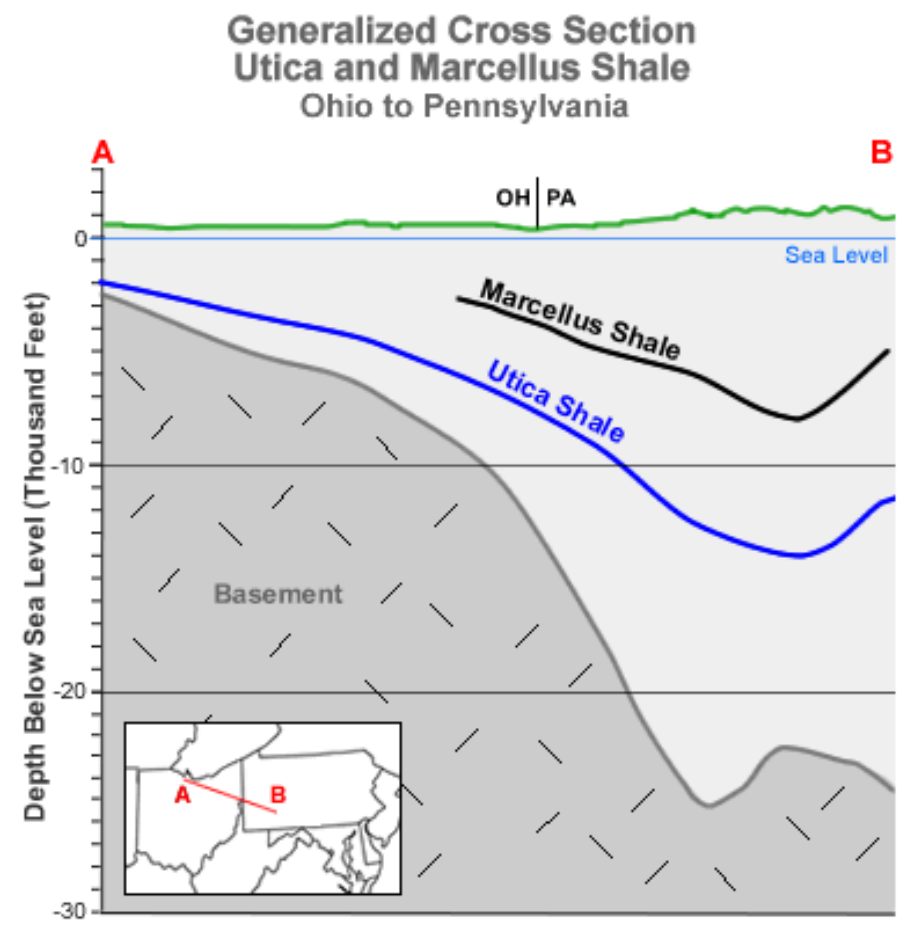

Figure 3: Utica generalized cross-section Ohio to Pennsylvania (http://www.dnr.state.oh.us/tabid/23014/default.aspx)

Figure 4 below shows a generalized cross-section of the Utica as we move across the border between New York and Pennsylvania. 


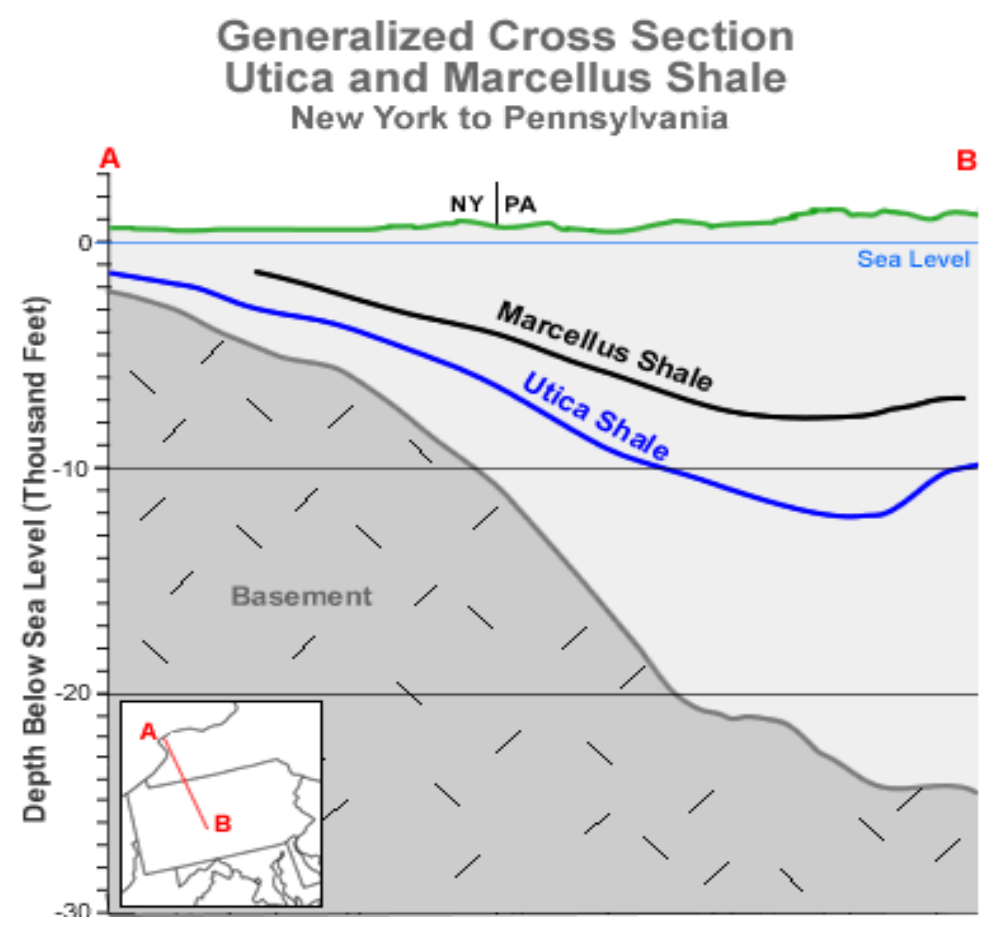

\section{Figure 4: Utica generalized cross-section New York to Pennsylvania} (http://www.dnr.state.oh.us/tabid/23014/default.aspx)

A useful tool which can enable us to understand the value of the Utica shale is reservoir modeling and simulation in conjunction with parametric sensitivity studies. The reservoir simulation and modeling can guide us in determining the changes that can lead to increased hydrocarbon production in the Utica shale. Furthermore, the potential of the Utica shale can be established through reservoir modeling and simulation. Once a model is built from real geological and physical properties data, numerous runs can be executed by using a reservoir simulator. In each run, a different value can be used for certain parameters to determine the best possible combinations in a well, in order to maximize production.

Figure 5 below displays the Utica shale in Quebec. The darkly colored formation is organic rich Utica shale while the light colored formation is limestone. 


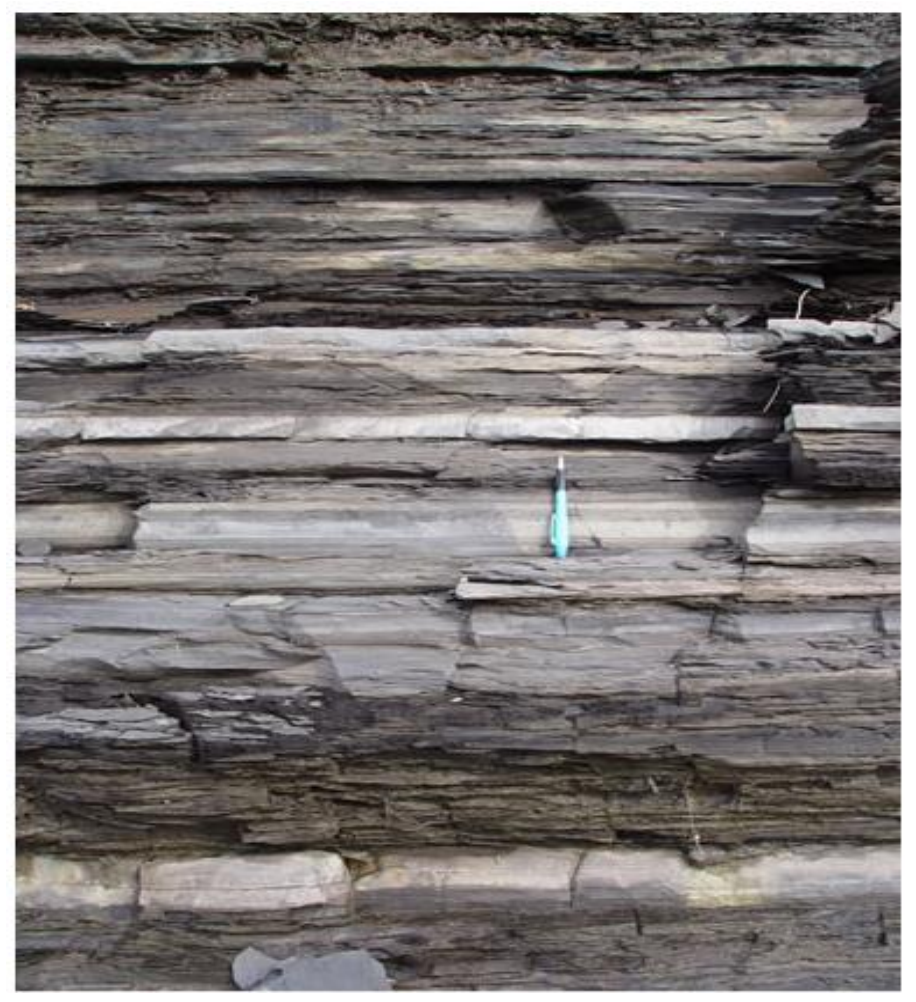

Figure 5: Dark organic rich Utica shale formation in Quebec (http://www.dnr.state.oh.us/tabid/23014/default.aspx)

The Figure 6 below shows energy use by sources in the US and production. Roughly a fourth of US energy is produced out of natural gas. The amount of shale gas has increased steadily over the last few years and it is expected that shale gas may deliver up to $45 \%$ of total natural gas produced in the US by 2035 . 


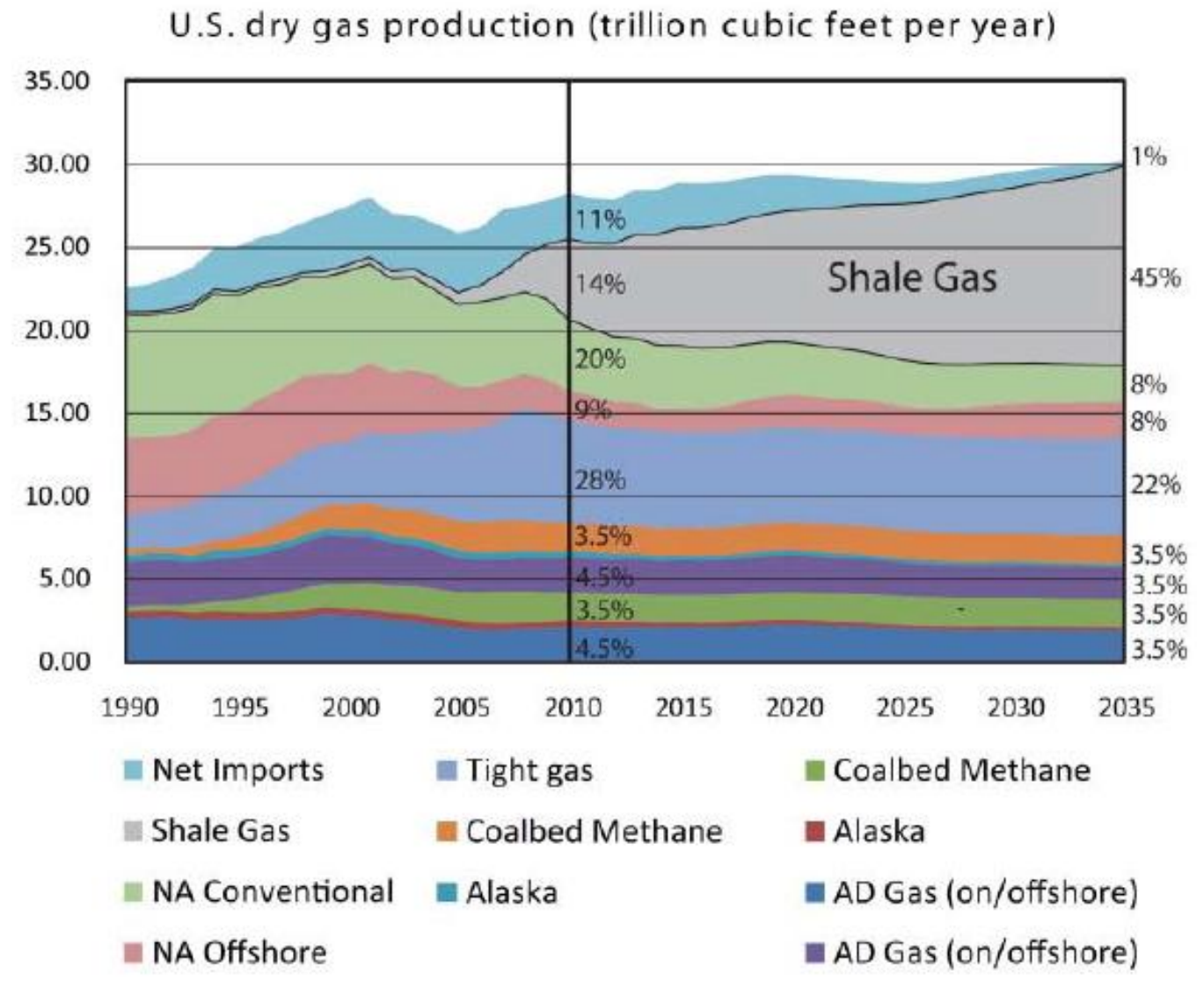

Figure 6: U.S. energy use and production (http://www.dnr.state.oh.us/tabid/23014/default.aspx) 


\section{Chapter II-Statement of Problem}

This research seeks to find the most optimum way of producing gas from the Utica shale via the means of reservoir modeling and simulation. In this research, production from horizontal wells without fractures will be compared to other horizontal well designs with lateral length varying from 2000 to $6000 \mathrm{ft}$, in $2000 \mathrm{ft}$ increments as well as fracture half length varying from 300 to $900 \mathrm{ft}$, in $300 \mathrm{ft}$ increments. In addition, an economic evaluation will be conducted in order to reach a conclusion on the best way to produce from the Utica shale. Previously, limited work has been done on hydraulic fracture optimization. Pinkhouse et. al. (2006) performed research on optimizing hydraulic fracturing performance in Northeastern United States fractured shale formations.

The objective of this research is to maximize gas production from the Utica shale through well design, fracture design and economic evaluation. For this research, commercially available reservoir modeling and simulation software is used to investigate the Utica shale production. In order to build a reservoir model that can accurately simulate an average Utica shale formation, extensive literature review and data collection were initiated. This research seeks to evaluate if it is economically warranted to drill several horizontal well designs which is often expensive in most shale formations.

Once all of the production data are obtained, an economic analysis was conducted to determine the most optimal designs for the wells. All of the modeling and production forecasting are completed utilizing a reservoir simulator. 
Analysis was performed in order to understand the effect of well type, lateral length of horizontal wells, effect of single fracture, effect of multiple fractures and the effect of fracture half length on production from the Utica. Finally, economic analysis was performed on the wells and fracture designs in order to select an optimum design.

In order to accomplish the objective of this study, the following procedure will be followed:

Building a reservoir model which is capable of producing methane (natural gas) from deep and thick shale reservoirs with various well and fracture designs.

$>$ Performing economic analysis on the horizontal well designs in order to identify the best drilling pattern in deep and thick Utica shale reservoirs, and to evaluate the recovery factors. 


\section{Model Nomenclature for Reservoir Simulation}

To study the effect of well designs on shale gas production from the Utica Shale, reservoir modeling study was conducted. To simulate production data for the Utica Shale wells, CMG software was used, a total of 28 different simulations were conducted. Only one parameter was changed at a time to hold the validity of the effect of the parameter that was investigated, after this is done, comparison was then made to the effects of the changes of lateral lengths, fracture treatments and number of half lengths.

Table 1 below shows the reservoir model designations that were used for this research. OXf represents zero fracture treatment while $5 \mathrm{Xf}$ represents five fracture treatments. The numbers appearing after Xf indicates the fracture half length. For example, 3Xf300 means a well with 300

$\mathrm{ft}$ half length and three fracture treatments. Also, the number preceding $3 \mathrm{Xf} 300$ represents the lateral length of the well. For example 20003 Xf600 refers to a well with $2000 \mathrm{ft}$ lateral, three fracture treatments and a $600 \mathrm{ft}$ half-length. 
Table 1: Well designs used in the study.

\begin{tabular}{|c|c|c|c|}
\hline Well Designation & Lateral length, ft & Half-length, $\mathrm{ft}$ & $\begin{array}{l}\text { \# of frac } \\
\text { treatments }\end{array}$ \\
\hline $20000 \times f 0$ & 2000 & 0 & 0 \\
\hline $20003 \times f 300$ & 2000 & 3 & 300 \\
\hline $20003 \times f 600$ & 2000 & 3 & 600 \\
\hline $20003 \times f 900$ & 2000 & 3 & 900 \\
\hline $20005 \times f 300$ & 2000 & 5 & 300 \\
\hline $20005 \times f 600$ & 2000 & 5 & 600 \\
\hline $20005 \times f 900$ & 2000 & 5 & 900 \\
\hline $40000 \times f 0$ & 4000 & 0 & 0 \\
\hline $40003 \times f 300$ & 4000 & 3 & 300 \\
\hline $40003 \times f 600$ & 4000 & 3 & 600 \\
\hline $40003 \times f 900$ & 4000 & 3 & 900 \\
\hline $40005 \times f 300$ & 4000 & 5 & 300 \\
\hline $40005 \times f 600$ & 4000 & 5 & 600 \\
\hline 40005 Xf900 & 4000 & 5 & 900 \\
\hline $40009 \times f 300$ & 4000 & 9 & 300 \\
\hline $40009 \times f 600$ & 4000 & 9 & 600 \\
\hline $40009 \times f 900$ & 4000 & 9 & 900 \\
\hline $60000 \times f 0$ & 6000 & 0 & 0 \\
\hline $60003 \times f 300$ & 6000 & 3 & 300 \\
\hline $60003 \times f 600$ & 6000 & 3 & 600 \\
\hline $60003 \times f 900$ & 6000 & 3 & 900 \\
\hline $60005 \times f 300$ & 6000 & 5 & 300 \\
\hline $60005 \times f 600$ & 6000 & 5 & 600 \\
\hline $60005 \times f 900$ & 6000 & 5 & 900 \\
\hline 200010 Xf300 & 2000 & 10 & 300 \\
\hline $200010 \times f 600$ & 2000 & 10 & 600 \\
\hline $400020 \times f 300$ & 4000 & 20 & 300 \\
\hline 600015 xf300 & 6000 & 15 & 300 \\
\hline
\end{tabular}




\section{Chapter III- Approach}

Table 2 below shows reservoir parameters obtained for the Utica through history matching.

Schepers (2009) designed a reservoir model, assuming various values for reservoir parameters as

long as these values were within reasonable range for the Utica. He then obtained production data from a company. Finally, he ran his reservoir model and obtained cumulative gas production curves which were different from those obtained from the companies who were drilling in the Utica.

Table 2: Parameters via deterministic approach-History matching. http://www.spe.org/events/lacpec/2009/en/technical/documents/123057 Karine Schepers.pdf

\begin{tabular}{|c|c|c|}
\hline Reservoir Parameters & Units & Value \\
\hline Thickness & $\mathrm{ft}$ & 400 \\
\hline Elevation & $\mathrm{ft}$ & 4000 \\
\hline Initial Pressure Gra dient & $\mathrm{psi} / \mathrm{ft}$ & 0.30 \\
\hline Reservoir Temperature & $\mathrm{F}$ & 80 \\
\hline Matrix Porosity & $\%$ & 5 \\
\hline Fracture Porosity & $\%$ & 0.60 \\
\hline Matrix Permeability $(\mathrm{Kx}=\mathrm{K} z)$ & $\mathrm{mD}$ & $5.10^{-4}$ \\
\hline Fracture Permeability $(K x=K z)$ & $\mathrm{mD}$ & $3.10^{3}$ \\
\hline Permeability Anisotropy & - & 5 \\
\hline Initial Water Saturation & $\%$ & $\mathbf{0}$ \\
\hline Matrix Block Size & $\mathrm{ft}$ & 10 \\
\hline In-situ Langmuir Volume & $\mathrm{scf} / \mathrm{t}$ & 52 \\
\hline Langmuir Pressure & psia & 375 \\
\hline Gas Saturation & $\%$ & 100 \\
\hline \multicolumn{3}{|l|}{ Fluid Para meters } \\
\hline Gas Gravity & & 0.55 \\
\hline Water Visocity & $\mathrm{cp}$ & 0.86 \\
\hline Water Formation Volume Factor & RB/STB & 1_O1 \\
\hline Water Density & $\mathrm{Ibm} / \mathrm{cuft}$ & 623 \\
\hline Gas Composition & $\% \mathrm{CH} 4$ & 100 \\
\hline \multicolumn{3}{|c|}{ Matrix Relative Permea bility Curves (Corey function) } \\
\hline Irreducible Water Saturation & $\%$ & $\mathbf{0}$ \\
\hline Residual Gas Saturation & $\%$ & $\mathbf{0}$ \\
\hline Maximum Gas Relative Permeability & $v / v$ & 1 \\
\hline Maximum Water Relative Permeability & $\mathrm{v} / \mathrm{v}$ & 1 \\
\hline Corey Exponents (water and gas) & $\mathrm{v} / \mathrm{v}$ & 1 \\
\hline \multicolumn{3}{|c|}{ Fracture Relative Permeability Curves (Corey function) } \\
\hline Irreducible Water Saturation & $\%$ & $\mathbf{0}$ \\
\hline Maximum Gas Relative Permeability & $\mathrm{v} / \mathrm{v}$ & 1 \\
\hline Maximum Water Relative Permeability & $\mathrm{v} / \mathrm{v}$ & 1 \\
\hline Residual Gas Saturation & $\%$ & $\mathbf{0}$ \\
\hline Corey exponent (water and gas) & $\mathrm{v} / \mathrm{v}$ & 1 \\
\hline \multicolumn{3}{|l|}{ Well Parameters } \\
\hline Wellbore Radius & $\mathrm{ft}$ & 0.27 \\
\hline
\end{tabular}


Consequently, he kept changing the values of his reservoir parameters, within the reasonable range, until his gas cumulative production curve matched with those of the company. This method of finding out reservoir parameters/properties is called history matching. For this research, a reservoir model will be built using data obtained from literature review and research.

In this research, a Cartesian grid, totaling 5000 grid blocks $(100 \times 50)$ was used. A dual porosity/dual permeability shale gas reservoir model was built with a $6000 \mathrm{ft}$ depth and a net thickness of $300 \mathrm{ft}$. The model was designed as a homogeneous shale gas reservoir. With fracture width was set at $0.001 \mathrm{ft}$. Runs were conducted for a period of 30 years.

Figures 7, 8, 9 and 10 below show the Utica shale reservoir models in $2 \mathrm{D}$ as well as four horizontal wells drilled in the middle of a Cartesian grid. Figure 7 shows a well with $2000 \mathrm{ft}$ lateral length, ten frac treatments and $600 \mathrm{ft}$ half-length which is represented by $200010 \mathrm{Xf600}$. Similarly, figures 8, 9 and 10 represent wells with designs 4000 20Xf300, 600015 Xf300 and 4000 9Xf900 respectively. The descriptions of these wells can be found on Table 1. 


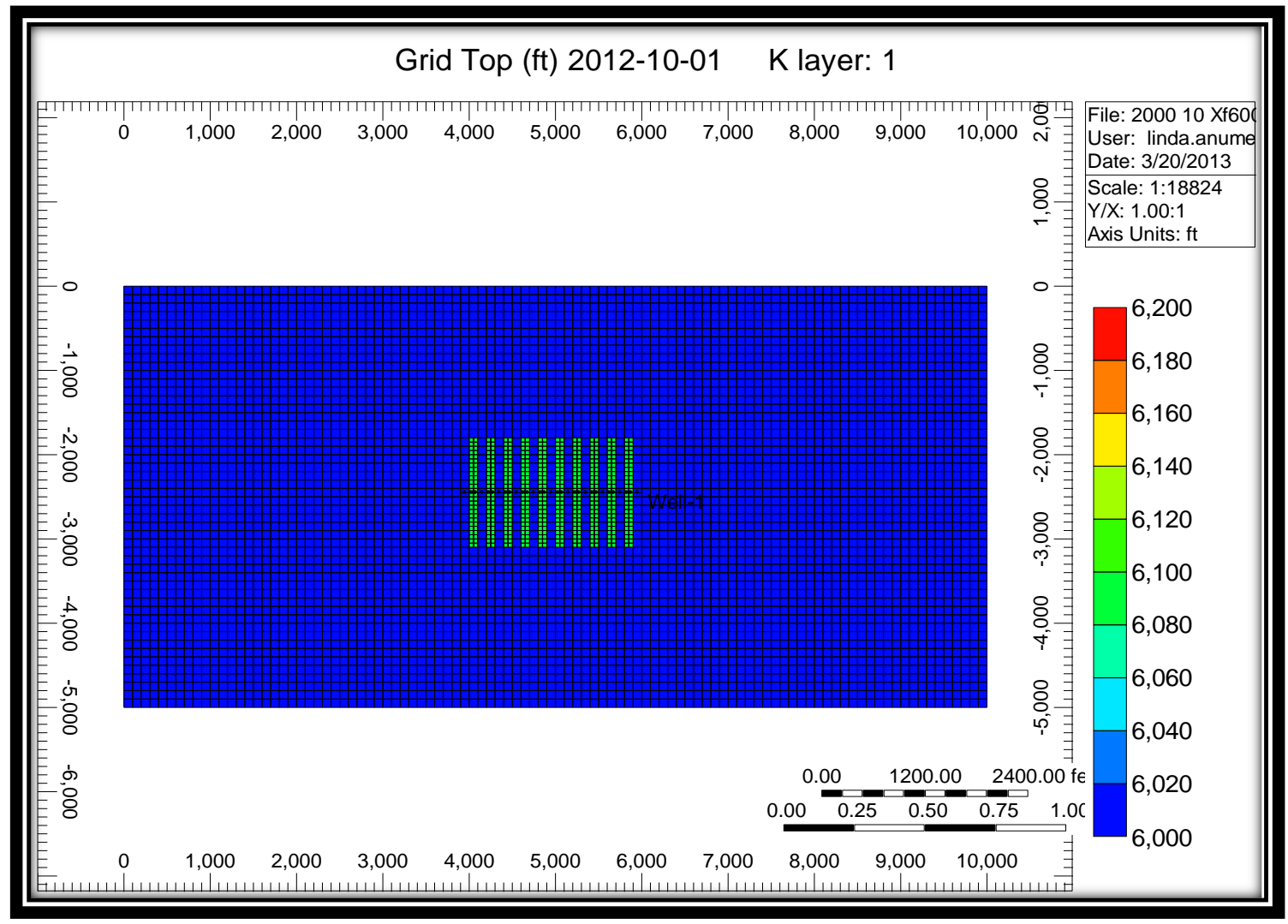

Figure 7: Well design with $2000 \mathrm{ft}$ lateral and 10 fracture treatments of $600 \mathrm{ft}$ half lengths. 


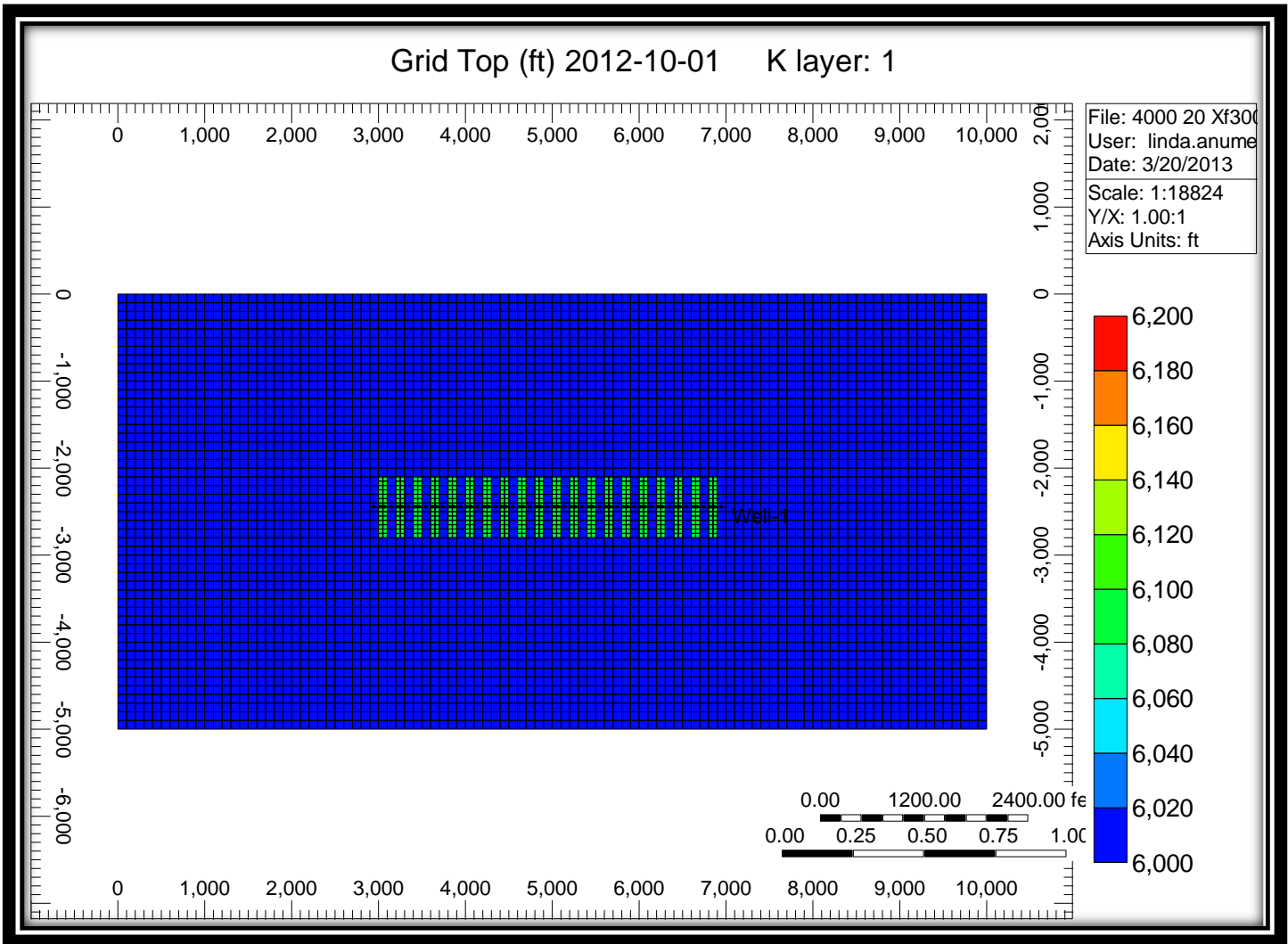

Figure 8: Well design with $4000 \mathrm{ft}$ lateral and 20 fracture treatments of $300 \mathrm{ft}$ half lengths. 


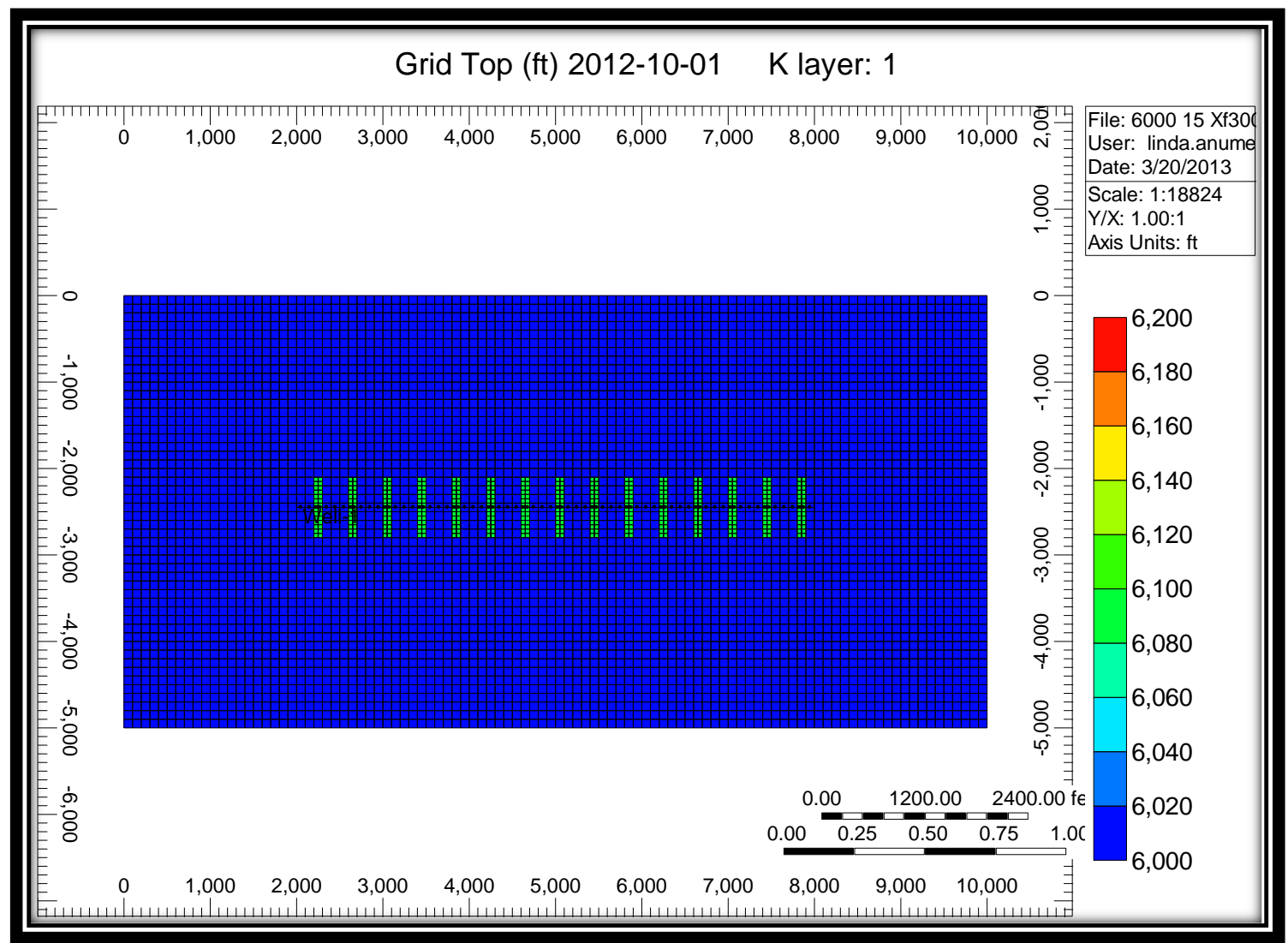

Figure 9: Well design with $6000 \mathrm{ft}$ lateral and 15 fracture treatments of $300 \mathrm{ft}$ half lengths. 


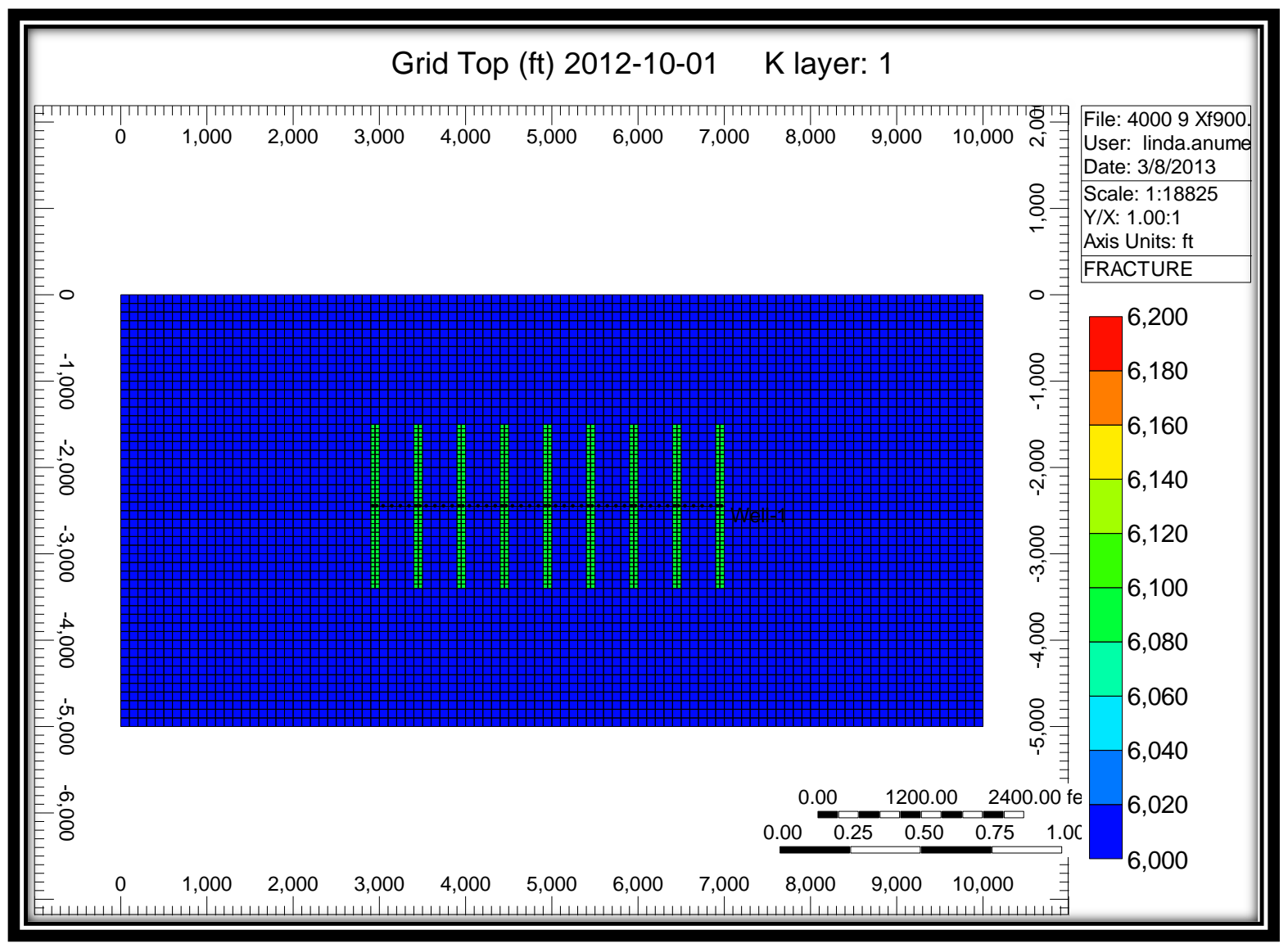

Figure 10: Well design with $4000 \mathrm{ft}$ lateral and 9 fracture treatments of $900 \mathrm{ft}$ half lengths. 
Figure 11 shows the horizontal well design used to represent a $4000 \mathrm{ft}$ lateral with 20 treatments of $300 \mathrm{ft}$ fracture half lengths.

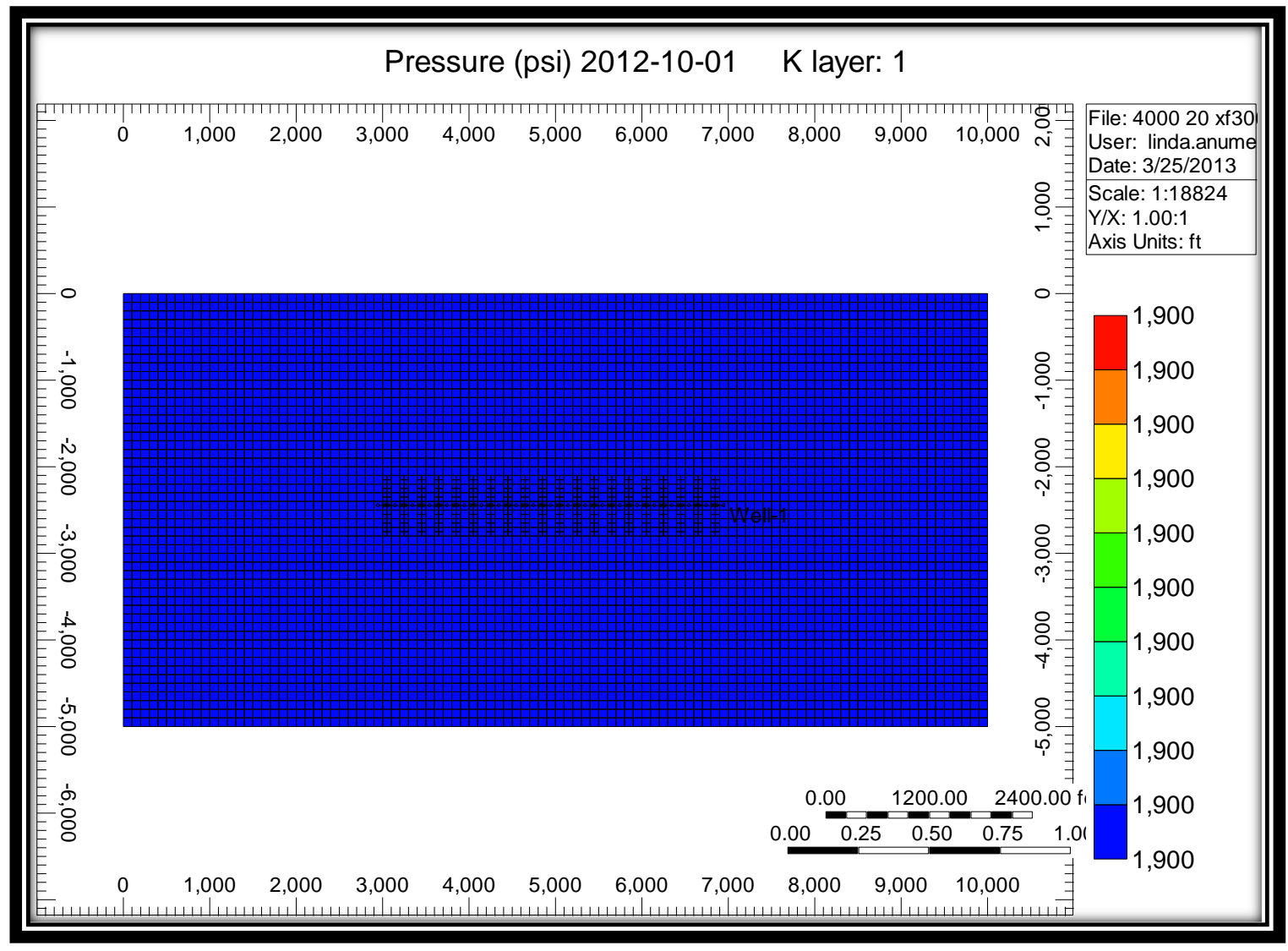

Figure 11: Well design with $4000 \mathrm{ft}$ lateral and 20 fracture treatments of $300 \mathrm{ft}$ half lengths.

Figure 12 represents 3D representation of well design with $2000 \mathrm{ft}$ lateral and 3 fracture treatments of $900 \mathrm{ft}$ half lengths. Figure 13 shows the 3D representation of well design with 4000 $\mathrm{ft}$ lateral and 3 fracture treatments of $900 \mathrm{ft}$ half lengths and figure 14 shows 3D representation of well design with $6000 \mathrm{ft}$ lateral and 3 fracture treatments of $900 \mathrm{ft}$ half lengths. 


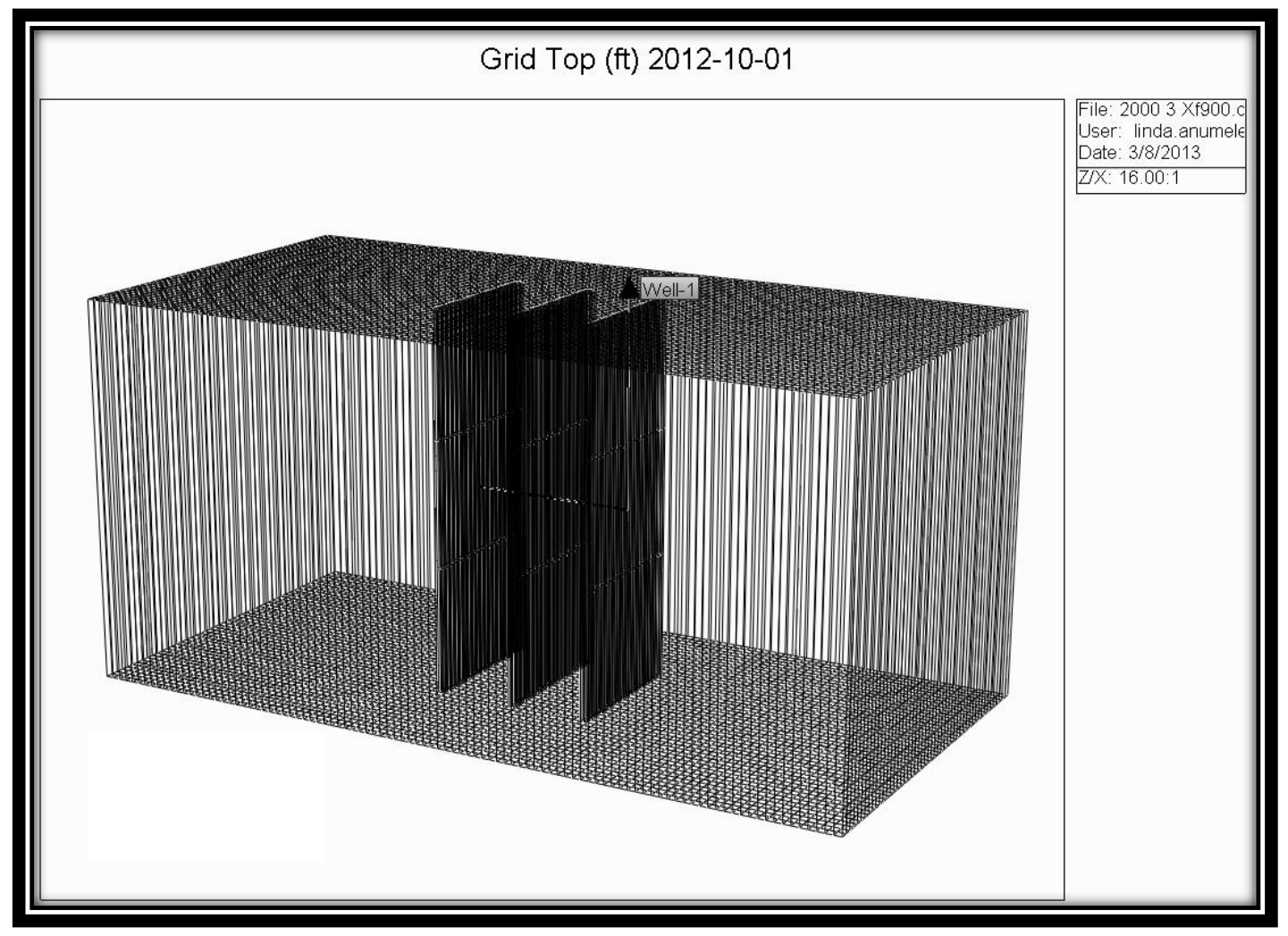

Figure 12: 3D representation of well design with $2000 \mathrm{ft}$ lateral and 3 fracture treatments of $900 \mathrm{ft}$ half lengths. 


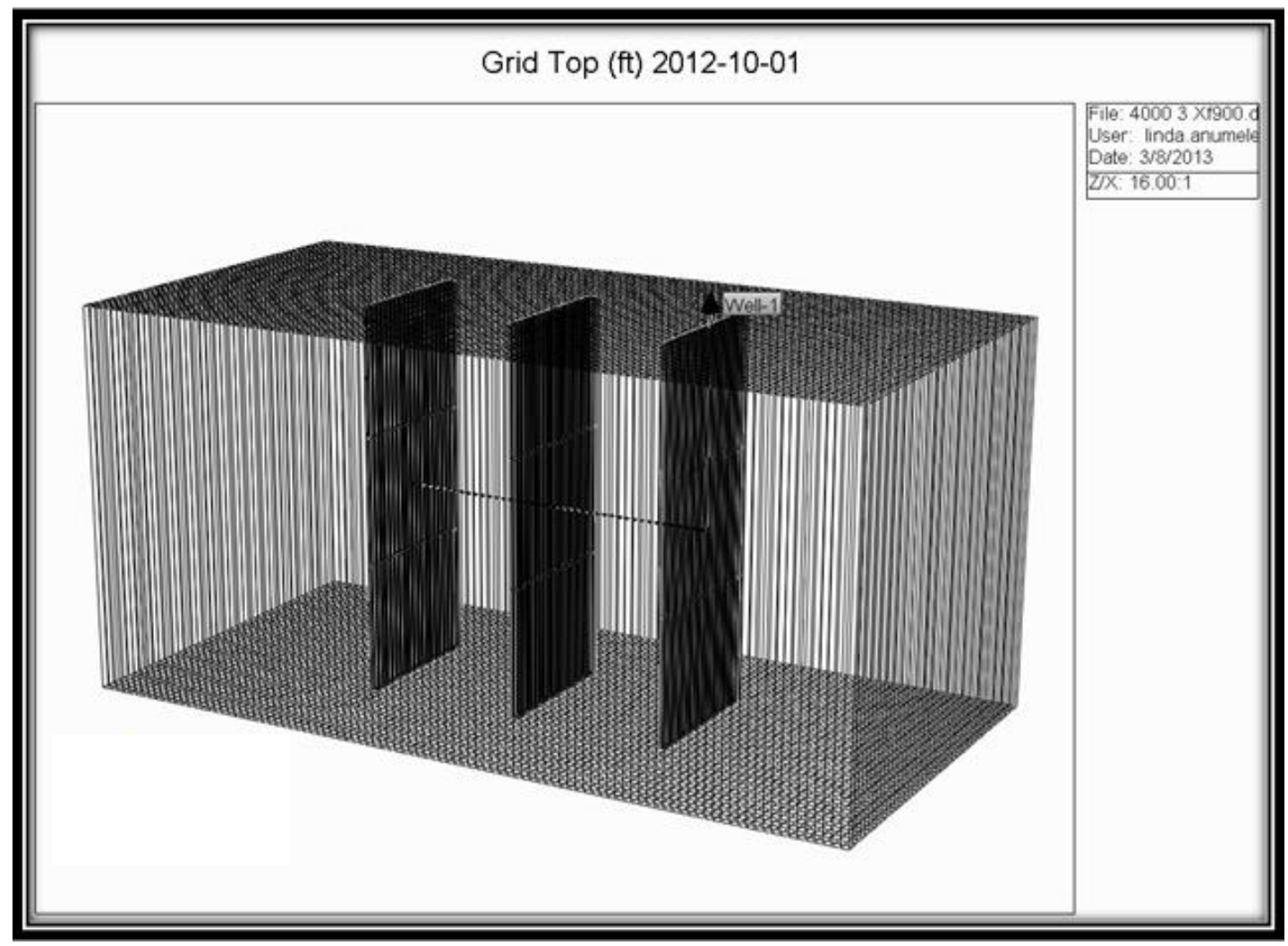

Figure 13: 3D representation of well design with $4000 \mathrm{ft}$ lateral and 3 fracture treatments of $900 \mathrm{ft}$ half lengths. 


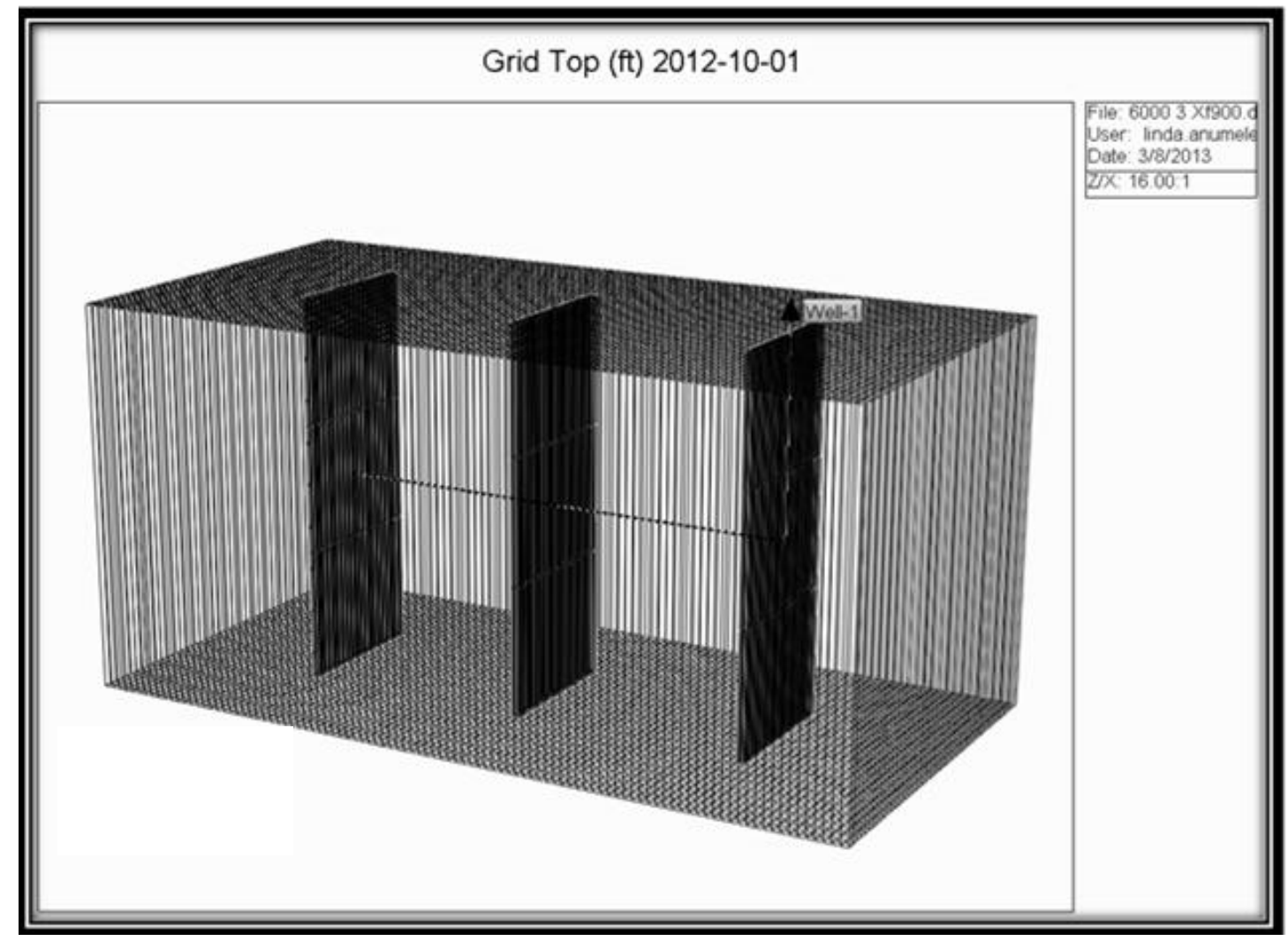

Figure 14: 3D representation of well design with $6000 \mathrm{ft}$ lateral and 3 fracture treatments of $900 \mathrm{ft}$ half lengths. 
Figure 15 below shows the well design for a horizontal well with $6000 \mathrm{ft}$ lateral and 5 fracture treatments of $900 \mathrm{ft}$ fracture half length.

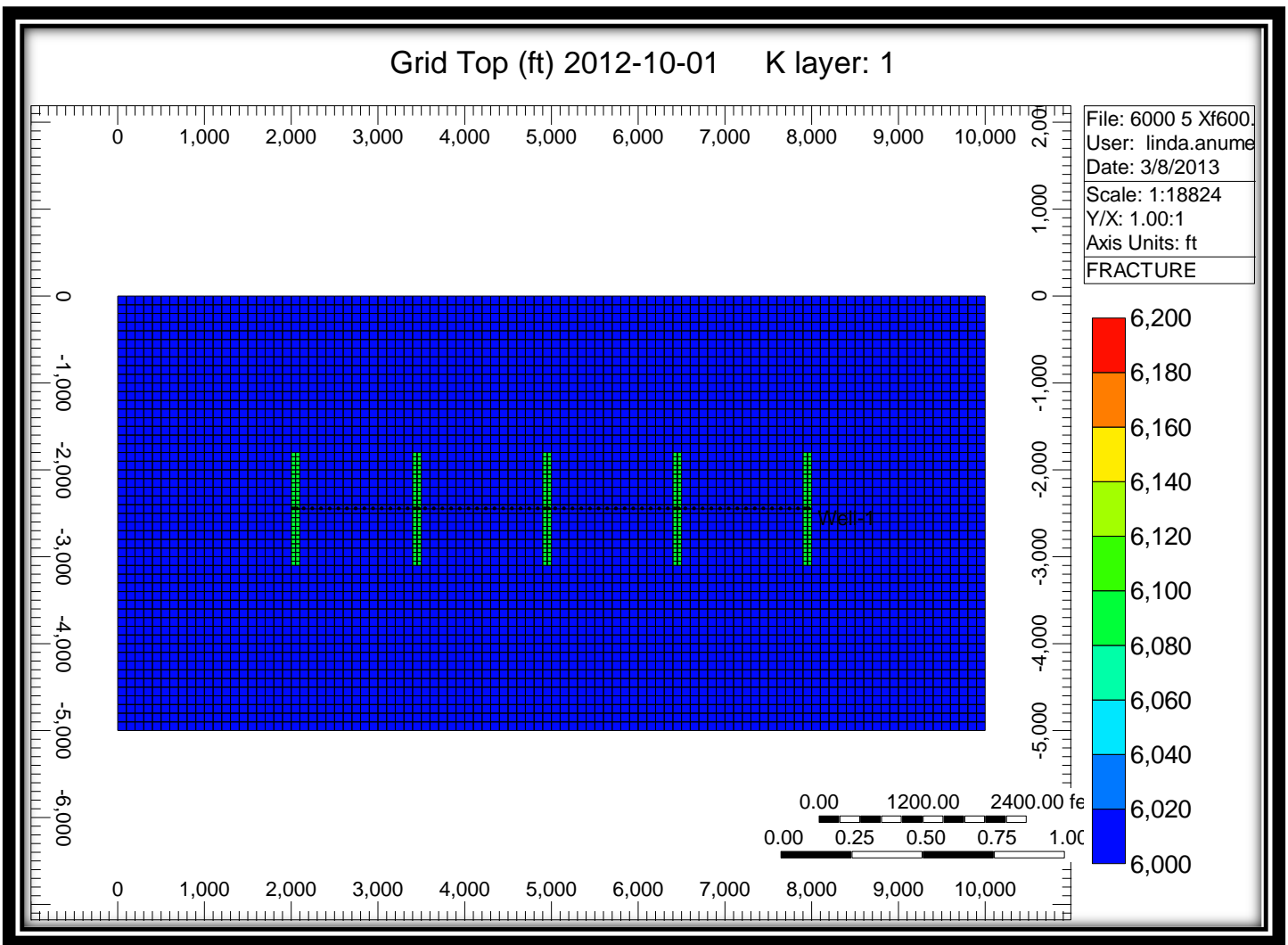

Figure 15: Well design with $6000 \mathrm{ft}$ lateral and 5 fracture treatments of $900 \mathrm{ft}$ half lengths.

Note the reservoir model designs above are just a few of many which will not be shown in this paper. The model pictures above have just been shown to boost the reader's understanding of the general orientation and location of the wells in addition to the general orientation of the fracture treatments and design. Finally, Appendix B shows the reservoir pressure distribution for 0, 10, 20 and 30 years for select reservoir models that were built and used in this research as shown from Figure Appendix 1 to Appendix 16. 


\section{Chapter IV-Economic Analysis}

This part of the research uses economic analysis as a basic financial tool to investigate various well designs in the Utica shale, the result of which shows either a profit or loss for the given well design. In order to determine the economic feasibility, a cash flow model is constructed for all simulation runs. The Net Present Value (NPV) was used to determine the economics of well design for the Utica shale reservoir.

The major factors affecting the economics of Utica shale reservoirs are as follows:

$>$ Natural Gas Price

$>$ Drilling Cost

$>$ Completion Cost

$>$ Royalty

$>$ Interest Rate

$>$ Operating cost

Along with the fact that the price of gas is projected to increase at some point in future, however, to predict the prices in the coming years is very difficult due to many factors impacting the market. Thus, several gas prices were used to cover the anticipated price range, namely $\$ 3.5$, $\$ 4.0$ and \$5.0 per MSCF. The drilling cost includes the cost of various lateral length designs for horizontal wells with same vertical depth. The completion cost includes completing and fracturing a well and it is based on half length of the fracture and number of fracture treatments. The operating cost is based on the monthly cost of operating the well. 
Table 3 shows the drilling cost by well design for the selected cases used in this study. Table 4 shows the completion cost for a single fracture treatment based on the half length of the fracture treatment. Table 5 lists the value of other economic parameters used in the calculations.

Table 3: Drilling cost by Well Design.

\begin{tabular}{|c|c|}
\hline Horizontal Well Design (Drilling) & Cost \$ \\
\hline $2000 \mathrm{ft}$ lateral & $3,000,000$ \\
\hline $4000 \mathrm{ft}$ lateral & $5,000,000$ \\
\hline $6000 \mathrm{ft}$ lateral & $7,000,000$ \\
\hline
\end{tabular}

Table 4: Completion cost by Well Design.

\begin{tabular}{|c|c|}
\hline Frac Half Length Well Design (Completions) & Cost \$ \\
\hline $300 \mathrm{ft}$ & 130,000 \\
\hline $600 \mathrm{ft}$ & 175,000 \\
\hline $900 \mathrm{ft}$ & 220,000 \\
\hline 0 & 0 \\
\hline
\end{tabular}

Table 5: Economic Parameters.

\begin{tabular}{|c|c|}
\hline Economic Parameters & Value \\
\hline Operating cost, \$ per month & 1,600 \\
\hline Gas Prices \$/SCF & $3.5,4.0,5.0$ \\
\hline Interest Rate, $\%$ & 15 \\
\hline Royalty, $\%$ & 12.5 \\
\hline
\end{tabular}

The equation 1 below shows the formula used in the calculation of NPV values where $\mathrm{i}$ is the interest rate, $\mathrm{t}$ is the time period and $R_{t}$ is the cash flow.

$N P V(i, N)=\sum_{t=1}^{N} \frac{R_{t}}{(1+i)^{t}}$ Equation 1

A fixed interest rate of $15 \%$ was used in this study. 
Table 6 below shows a sample economic analysis of NPV calculation for a $2000 \mathrm{ft}$ long horizontal well with three fracture treatments of $600 \mathrm{ft}$ half-length for a period of 30 years. Gas revenue is based on the yearly gas production obtained from the reservoir model. Three different gas prices were considered with $12.5 \%$ royalty. All calculations are based on pre- tax value, due to the changes in tax rates used by different states. 
Table 6: NPV analysis for $2000 \mathrm{ft}$ lateral horizontal well with three fracture treatments and $600 \mathrm{ft}$ fracture half length in the Utica after 30 years.

\begin{tabular}{|c|c|c|c|c|c|c|c|c|c|}
\hline \multirow[b]{2}{*}{ DATE } & \multirow{2}{*}{$\begin{array}{c}\text { Yearly Production } \\
\text { SC }\end{array}$} & \multirow[b]{2}{*}{ Revenue, \$ } & \multirow{2}{*}{$\begin{array}{c}\text { Revenue after } \\
\text { royalty, } \$\end{array}$} & \multicolumn{3}{|c|}{ Well Design Cost, \$ } & \multirow{2}{*}{$\begin{array}{c}\text { Cash flow, } \$ \\
\text { (after expenses) }\end{array}$} & \multicolumn{2}{|c|}{ NPV @ 15\% } \\
\hline & & & & Operating & Drilling & Completions & & Discount factor & Discount cash flow, $\$$ \\
\hline oct 1-2012 & & & 0 & & $3,000,000$ & 525,000 & $(3,525,000.00)$ & $\begin{array}{r}1.0000 \\
\end{array}$ & $(3,525,000.00)$ \\
\hline oct 1-2013 & 407982656 & $1,427,939.30$ & 1249446.884 & $19,200.0$ & & & $1,230,246.88$ & 0.8696 & $1,069,779.90$ \\
\hline oct 1-2014 & 286451584 & $1,002,580.54$ & 877257.976 & $19,200.0$ & & & $858,057.98$ & 0.7561 & $648,815.10$ \\
\hline oct 1-2015 & 238730688 & $835,557.41$ & 731112.732 & $19,200.0$ & & & $711,912.73$ & 0.6575 & $468,094.18$ \\
\hline oct $1-2016$ & 214060288 & $749,211.01$ & 655559.632 & $19,200.0$ & & & $636,359.63$ & 0.5718 & $363,840.68$ \\
\hline oct 1-2017 & 194926592 & $682,243.07$ & 596962.688 & $19,200.0$ & & & $577,762.69$ & 0.4972 & $287,250.17$ \\
\hline oct 1-2018 & 180718848 & $632,515.97$ & 553451.472 & $19,200.0$ & & & $534,251.47$ & 0.4323 & $230,971.65$ \\
\hline oct 1-2019 & 169299200 & $592,547.20$ & 518478.8 & $19,200.0$ & & & $499,278.80$ & 0.3759 & $187,697.39$ \\
\hline oct 1-2020 & 160251520 & $560,880.32$ & 490770.28 & $19,200.0$ & & & $471,570.28$ & 0.3269 & $154,157.16$ \\
\hline oct 1-2021 & 151780864 & $531,233.02$ & 464828.896 & $19,200.0$ & & & $445,628.90$ & 0.2843 & $126,675.54$ \\
\hline oct 1-2022 & 144854528 & $506,990.85$ & 443616.992 & $19,200.0$ & & & $424,416.99$ & 0.2472 & $104,909.39$ \\
\hline oct 1-2023 & 138793984 & $485,778.94$ & 425056.576 & $19,200.0$ & & & $405,856.58$ & 0.2149 & $87,236.12$ \\
\hline oct 1-2024 & 133784832 & $468,246.91$ & 409716.048 & $19,200.0$ & & & $390,516.05$ & 0.1869 & $72,990.24$ \\
\hline oct 1-2025 & 128619776 & $450,169.22$ & 393898.064 & $19,200.0$ & & & $374,698.06$ & 0.1625 & $60,898.91$ \\
\hline oct 1-2026 & 124294912 & $435,032.19$ & 380653.168 & $19,200.0$ & & & $361,453.17$ & 0.1413 & $51,083.69$ \\
\hline oct 1-2027 & 120366336 & $421,282.18$ & 368621.904 & $19,200.0$ & & & $349,421.90$ & 0.1229 & $42,942.03$ \\
\hline oct 1-2028 & 117088512 & $409,809.79$ & 358583.568 & $19,200.0$ & & & $339,383.57$ & 0.1069 & $36,268.15$ \\
\hline oct 1-2029 & 113465600 & $397,129.60$ & 347488.4 & $19,200.0$ & & & $328,288.40$ & 0.0929 & $30,506.49$ \\
\hline oct $1-2030$ & 110415616 & $386,454.66$ & 338147.824 & $19,200.0$ & & & $318,947.82$ & 0.0808 & $25,772.62$ \\
\hline oct 1-2031 & 107585280 & $376,548.48$ & 329479.92 & $19,200.0$ & & & $310,279.92$ & 0.0703 & $21,801.92$ \\
\hline oct 1-2032 & 105230848 & $368,307.97$ & 322269.472 & $19,200.0$ & & & $303,069.47$ & 0.0611 & $18,517.63$ \\
\hline oct 1-2033 & 102476544 & $358,667.90$ & 313834.416 & $19,200.0$ & & & $294,634.42$ & 0.0531 & $15,654.13$ \\
\hline oct 1-2034 & 100163840 & $350,573.44$ & 306751.76 & $19,200.0$ & & & $287,551.76$ & 0.0462 & $13,285.06$ \\
\hline oct 1-2035 & 97988352 & $342,959.23$ & 300089.328 & $19,200.0$ & & & $280,889.33$ & 0.0402 & $11,284.57$ \\
\hline oct 1-2036 & 95936512 & $335,777.79$ & 293805.568 & $19,200.0$ & & & $274,605.57$ & 0.0349 & $9,593.15$ \\
\hline oct 1-2037 & 93996288 & $328,987.01$ & 287863.632 & $19,200.0$ & & & $268,663.63$ & 0.0304 & $8,161.37$ \\
\hline oct 1-2038 & 92158208 & $322,553.73$ & 282234.512 & $19,200.0$ & & & $263,034.51$ & 0.0264 & $6,948.15$ \\
\hline oct 1-2039 & 90412800 & $316,444.80$ & 276889.2 & $19,200.0$ & & & $257,689.20$ & 0.0230 & $5,919.08$ \\
\hline oct 1-2040 & 88752640 & $310,634.24$ & 271804.96 & $19,200.0$ & & & $252,604.96$ & 0.0200 & $5,045.48$ \\
\hline oct 1-2041 & 87171328 & $305,099.65$ & 266962.192 & $19,200.0$ & & & $247,762.19$ & 0.0174 & $4,303.26$ \\
\hline oct 1-2042 & 86125824 & $301,440.38$ & 263760.336 & $19,200.0$ & & & $244,560.34$ & 0.0151 & $3,693.61$ \\
\hline & & & & & & & & Total NPV, \$ & $649,096.81$ \\
\hline
\end{tabular}




\section{CHAPTER V- Results and Discussion}

The results below show how cumulative production is affected by lateral length, frac half-length and number of fracture treatments. Notably, the analysis below generally shows the trend in cumulative production with respect to changes in lateral length, frac half-length or number of fracture treatments. For example, Figure 16 shows the effect of well lateral length on cumulative production and it is evident that as lateral length increases from $2000 \mathrm{ft}$ to $6000 \mathrm{ft}$, cumulative production increases; however, the amount of increased gas production by each well length is not

linearly related to lateral length size. The actual cumulative gas production values from each well design are listed in Table 7. 
Table 7: Cumulative gas production for different well designs

\begin{tabular}{|c|c|}
\hline Analyzed Well Designs & $\begin{array}{l}\text { Cumulative Gas } \\
\text { Production SCF }\end{array}$ \\
\hline $20003 \times f 300$ & $2,914,683,136.00$ \\
\hline $20003 \times f 600$ & $4,283,884,800.00$ \\
\hline $20003 \times f 900$ & $5,348,584,448.00$ \\
\hline $20005 \times f 300$ & $3,821,350,400.00$ \\
\hline $20005 \times f 600$ & $5,881,631,232.00$ \\
\hline 20005 Xf900 & $7,525,968,384.00$ \\
\hline $200010 \times f 300$ & $4,525,214,720.00$ \\
\hline 200010 Xf600 & $7,049,180,672.00$ \\
\hline $40003 \times f 300$ & $3,927,911,936.00$ \\
\hline $40003 \times f 600$ & $5,301,746,688.00$ \\
\hline $40003 \times f 900$ & $6,369,676,288.00$ \\
\hline $40005 \times f 300$ & $5,014,160,896.00$ \\
\hline $40005 \times f 600$ & $7,292,295,168.00$ \\
\hline 40005 Xf900 & $9,071,793,152.00$ \\
\hline $40009 \times f 300$ & $6,824,958,464.00$ \\
\hline $40009 \times f 600$ & $10,486,311,936.00$ \\
\hline $40009 \times f 900$ & $13,424,247,808.00$ \\
\hline $400020 \times f 300$ & $8,599,832,576.00$ \\
\hline $60003 \times f 300$ & $4,887,753,728.00$ \\
\hline $60003 \times f 600$ & $6,261,260,288.00$ \\
\hline $60003 \times f 900$ & $7,329,083,904.00$ \\
\hline $60005 \times f 300$ & $5,978,297,344.00$ \\
\hline $60005 \times f 600$ & $8,266,182,144.00$ \\
\hline 60005 Xf900 & $10,051,795,968.00$ \\
\hline 600015 Xf300 & $10,146,748,416.00$ \\
\hline
\end{tabular}




\section{Effect of Lateral Well Length on Cumulative Gas Production}

Figure 16 shows the cumulative gas production from three horizontal wells with $2000 \mathrm{ft}, 4000 \mathrm{ft}$ and 6000 $\mathrm{ft}$ laterals for a period of 30 years.

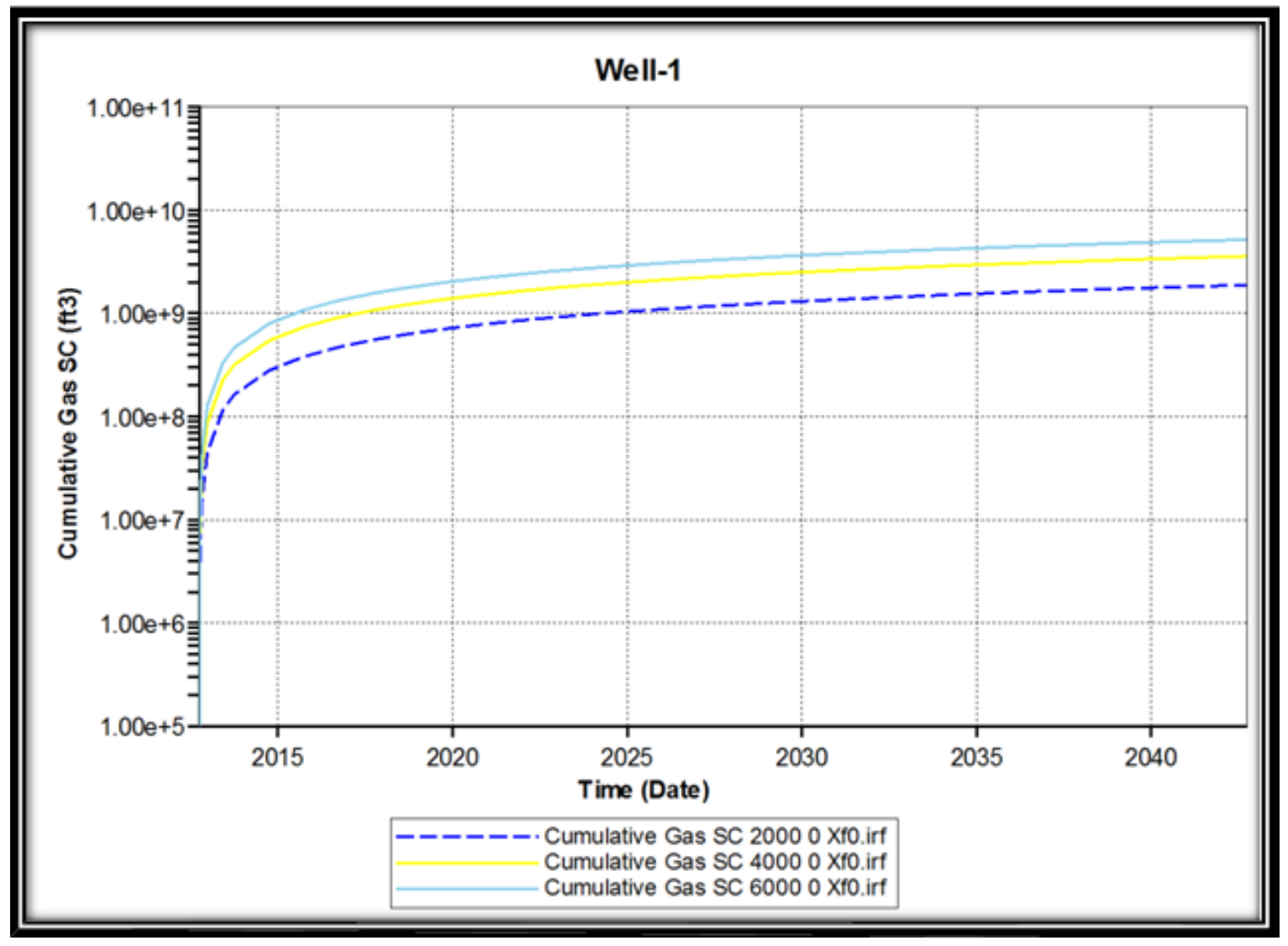

Figure 16: Comparison of cumulative gas production from three different lateral wells with no fracture treatments.

As can be seen from the plot, the horizontal well with the longest lateral $6000 \mathrm{ft} 96907207808$ MSCF produces more gas followed by the horizontal well with $4000 \mathrm{ft}$ lateral and 66666076928 MSCF more with $2000 \mathrm{ft}$ lateral 34828655600 MSCF. These lengths increase in the wellbore increases the gas production. However the cumulative gas production should justify the cost of extra length. 


\section{Effect of Number of fracture treatments on $2000 \mathrm{ft}$ lateral horizontal well with $300 \mathrm{ft}$ half length.}

Figure 17 shows the effect of number of fracture treatments on cumulative natural gas production on a $2000 \mathrm{ft}$ lateral horizontal well.

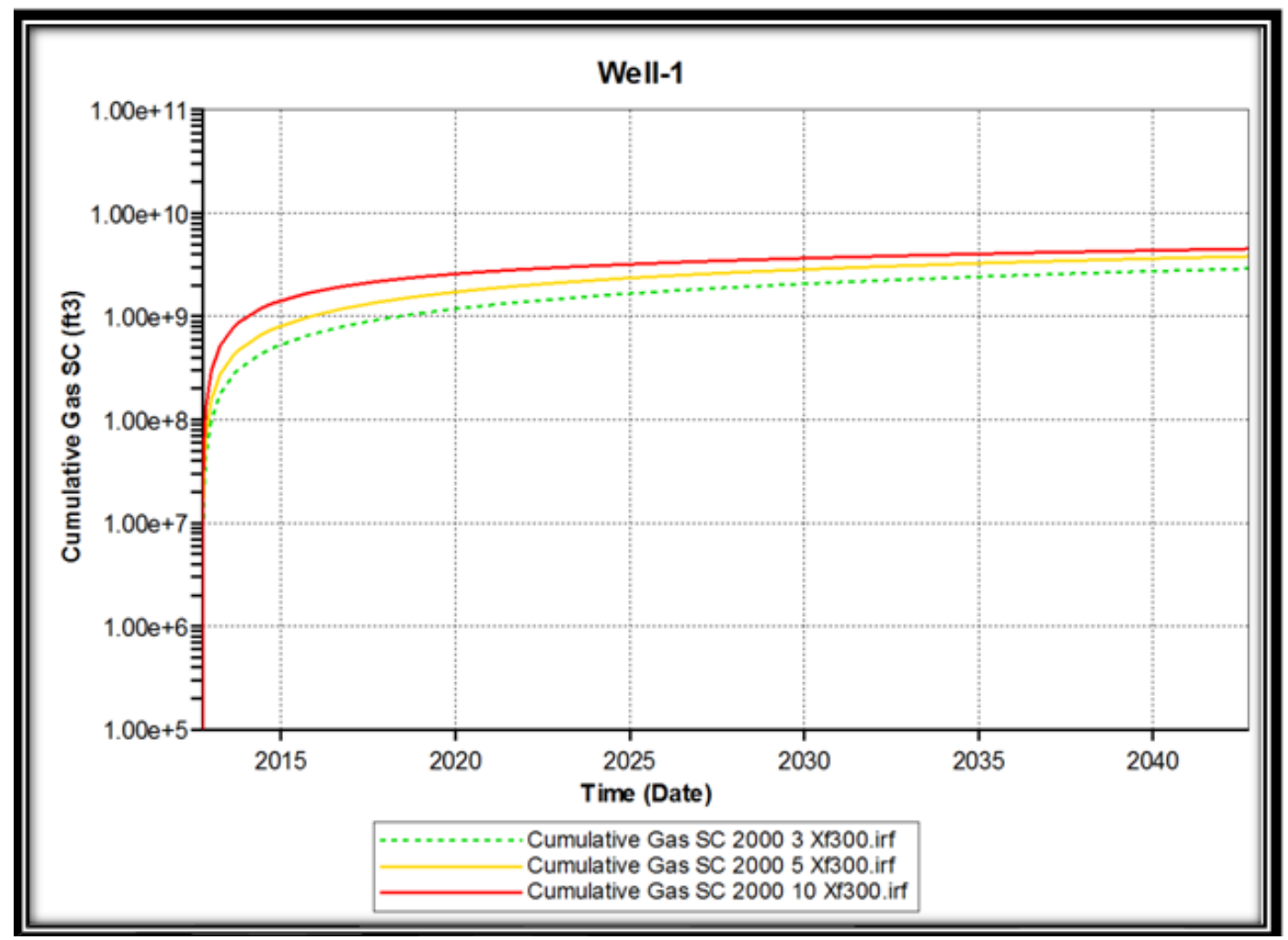

Figure 17: Comparison of cumulative gas production with different number of fracture treatments on $2000 \mathrm{ft}$ lateral well with $300 \mathrm{ft}$ half length.

Three different fracture treatments of 3,5 and 10 were increased as shown in the figure above, the well with the most number of fracture treatments (10) has the highest cumulative production for a period of 30 years followed by the wells with 5 and 3 fracture treatments respectively with half-length being constant at $300 \mathrm{ft}$. 


\section{Effect of Number of fracture treatments on $2000 \mathrm{ft}$ lateral horizontal well with $600 \mathrm{ft}$ half length.}

Figure 18 shows the effect of number of fracture treatments on cumulative natural gas production on a $2000 \mathrm{ft}$ lateral horizontal well.

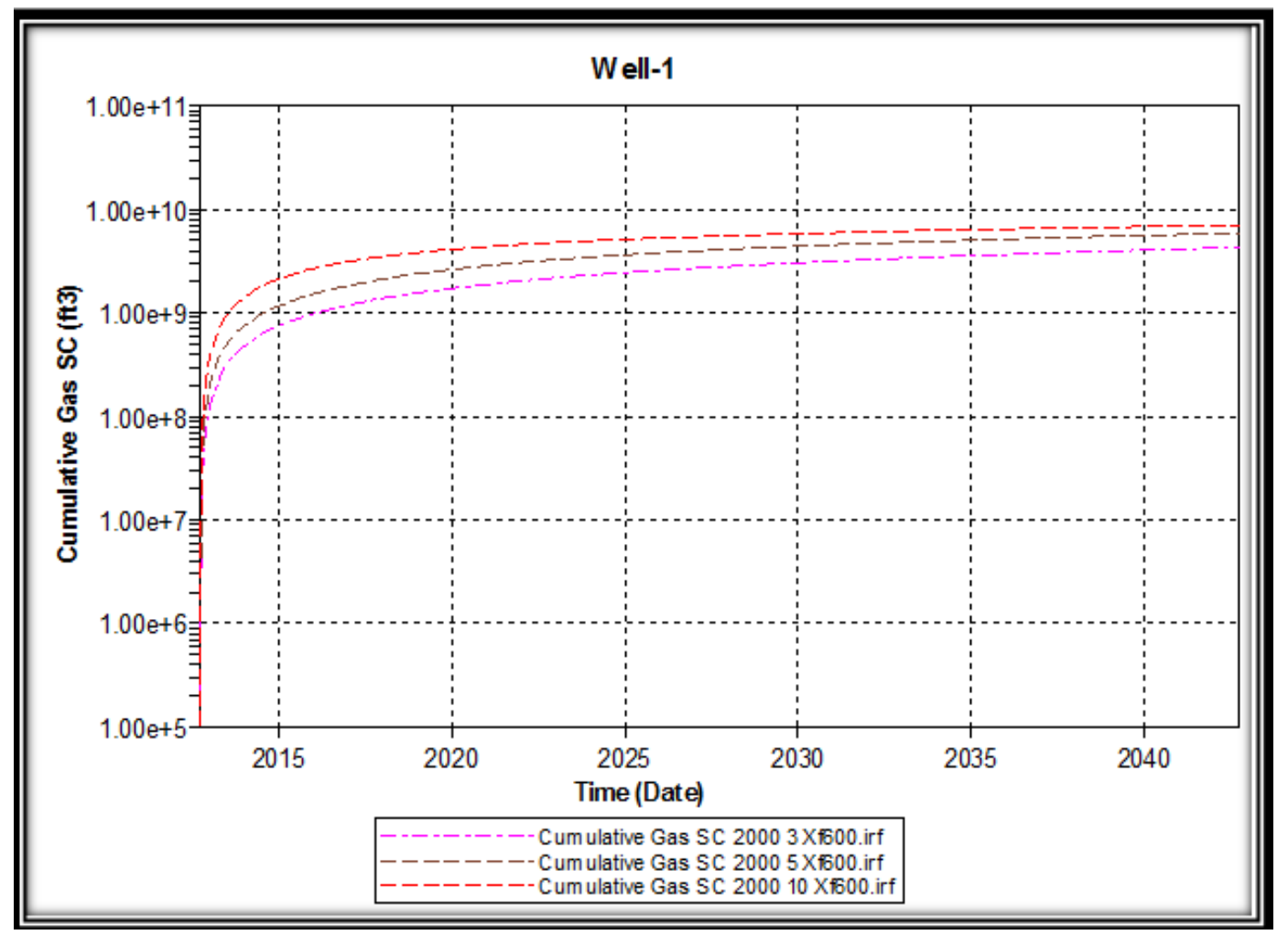

Figure 18: : Comparison of cumulative gas production with different number of fracture treatments on $2000 \mathrm{ft}$ lateral well with $600 \mathrm{ft}$ half length.

Similar to results with $300 \mathrm{ft}$ fracture half length, the cumulative gas production was 4,283,884,800MMSCF, 5,881,631,232 MMSCf and 7,049,180,672 MMSCF for 3, 5 and 20 treatments respectively. 


\section{Effect of Fracture Half Length on $2000 \mathrm{ft}$ Lateral horizontal well with 3 fracture treatments}

Figure 19 shows the effect of half-length sizes on cumulative natural gas production on a $2000 \mathrm{ft}$ lateral horizontal well with three fracture treatments.

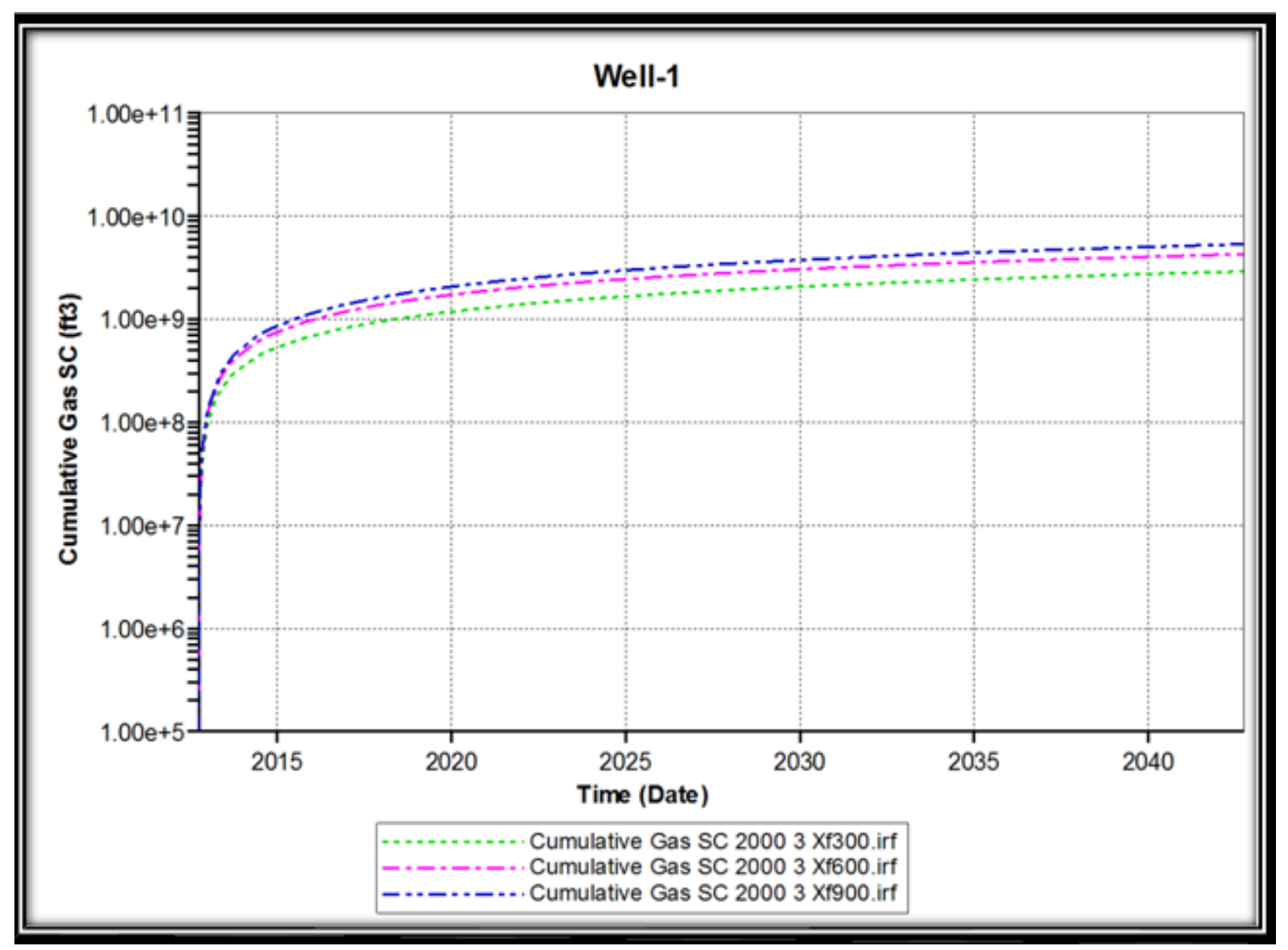

Figure 19: Comparison of cumulative gas production with different fracture half Length on $2000 \mathrm{ft}$ Lateral well with 3 fracture treatments.

As shown in the figure above the cumulative production for a period of 30 years increased from 2,914,683,136 MMSF to 5,348,448 MMSCF when fracture half length increased from $300 \mathrm{ft}$ to $900 \mathrm{ft}$. 


\section{Effect of Fracture Half Length on $2000 \mathrm{ft}$ Lateral horizontal well with $\mathbf{5}$}

fracture treatments

Figure 20 shows the effect of half-length sizes on cumulative natural gas production on a $2000 \mathrm{ft}$ lateral horizontal well with five fracture treatments.

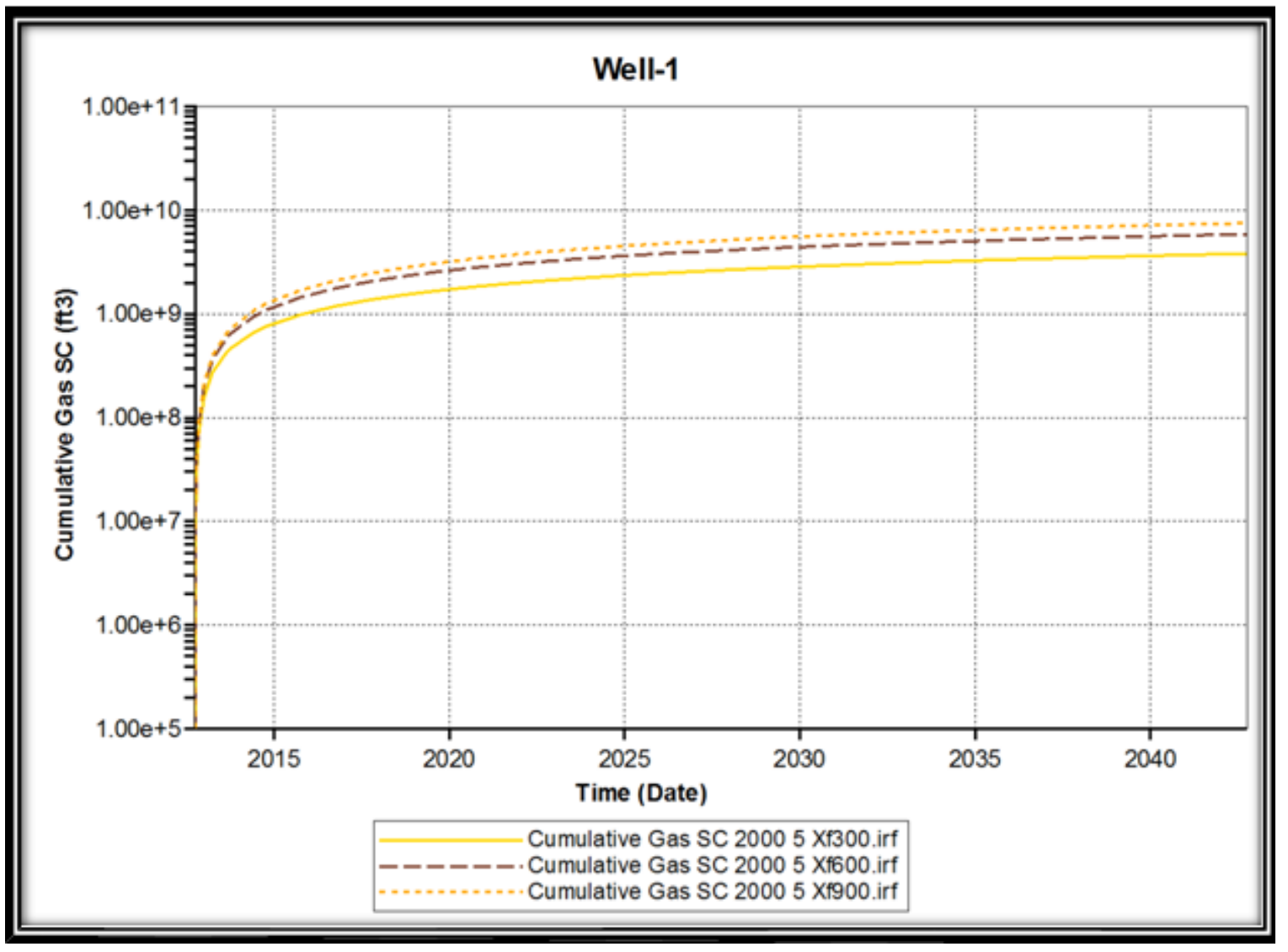

Figure 20: Comparison of cumulative gas production with different Fracture Half Lengths on $2000 \mathrm{ft}$ Lateral well with 5 fracture treatments

As shown in the figure above, the well with the longest fracture half-length (900 ft) has the highest cumulative production for a period of 30 years followed by the wells with 600 and $300 \mathrm{ft}$ fracture treatments respectively with fracture treatment being constant at three. 


\section{Effect of Number of fracture treatments on $4000 \mathrm{ft}$ lateral horizontal well with $300 \mathrm{ft}$ half length}

Figure 21 shows the effect of number of fracture treatment on cumulative natural gas production on a $4000 \mathrm{ft}$ lateral horizontal well. For all cases shown in Figure 21, the fracture half length of $300 \mathrm{ft}$ was used.

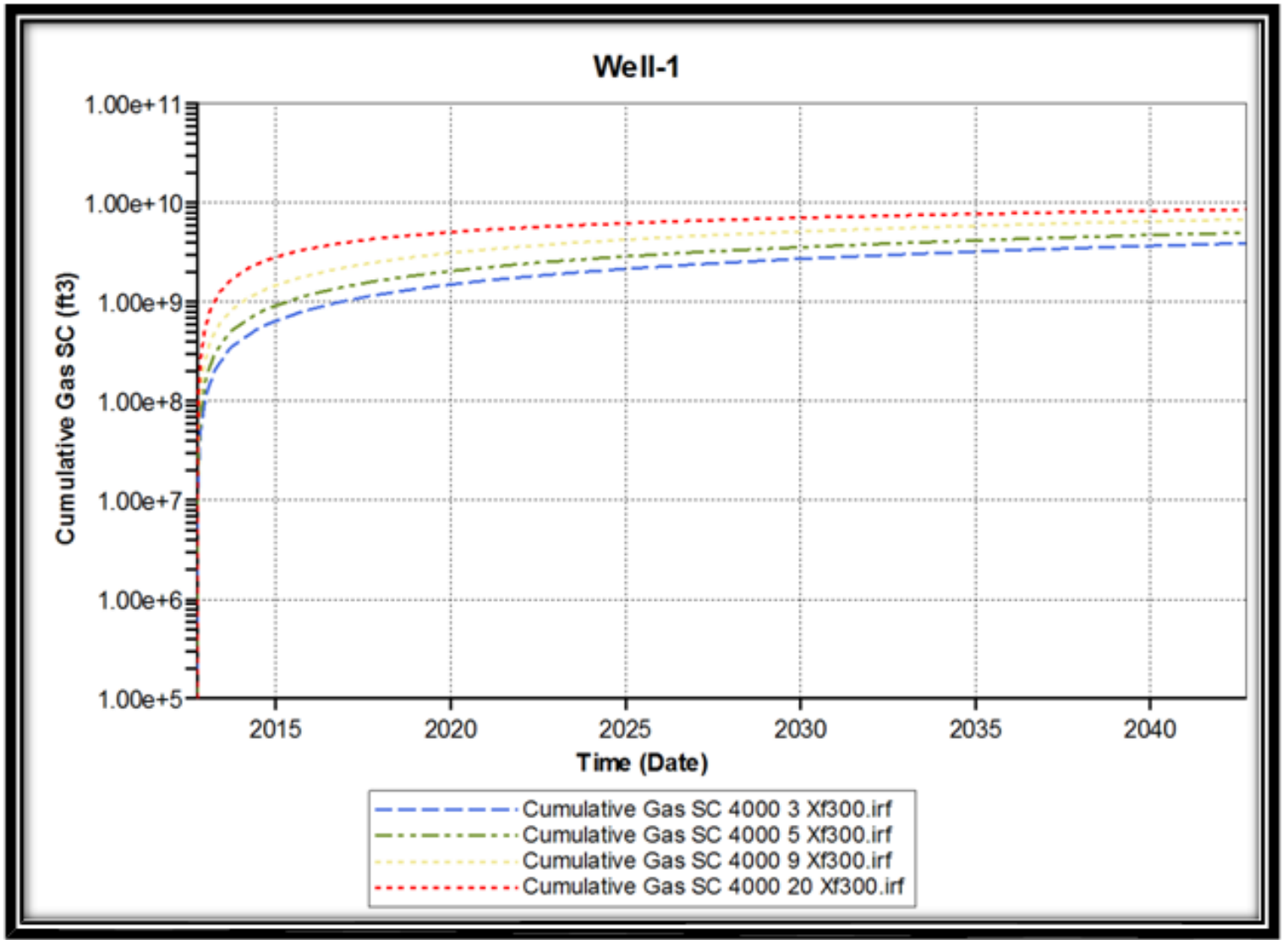

Figure 21: Comparison of cumulative gas production with different Number of fracture treatments on $4000 \mathrm{ft}$ lateral well with $300 \mathrm{ft}$ half length

The cumulative production for a period of 30 years increases from 3,927,911,936 MMSCF to 6,824,958,464 MMSCF when the number of fracture treatments increases from 3 to 9 . Further 
increase in the number of treatments to 20 increases the cumulative gas produced to $8,599,832,576 \mathrm{MMSCF}$ at end of 30 years.

\section{Effect of Number of fracture treatments on $4000 \mathrm{ft}$ lateral horizontal well with $600 \mathrm{ft}$ half length}

Figure 22 shows the effect of number of fracture treatment on cumulative natural gas production on a $4000 \mathrm{ft}$ lateral horizontal well.

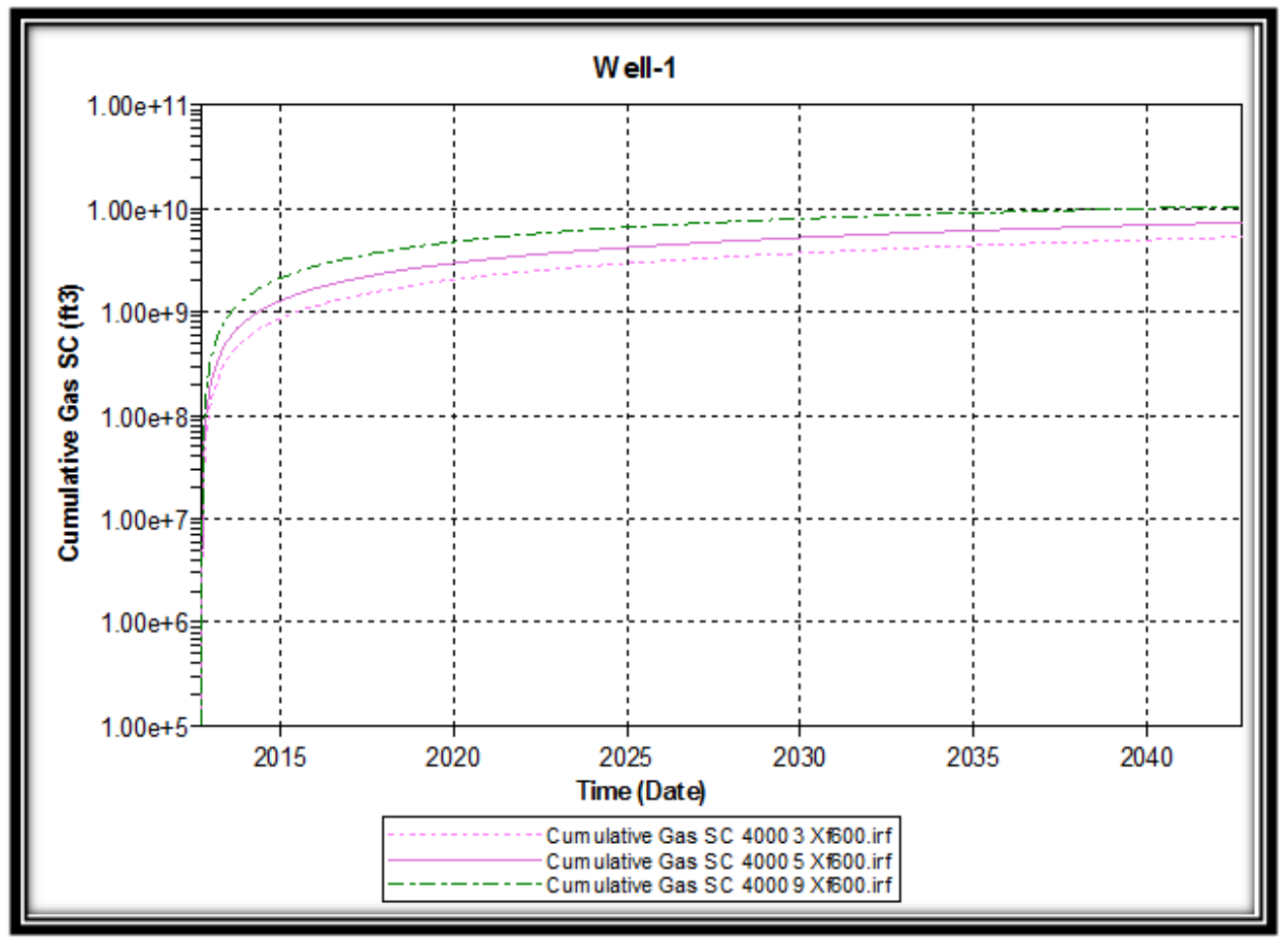

Figure 22: Comparison of cumulative gas production from Effect of Number of fracture treatments on $4000 \mathrm{ft}$ lateral well with $600 \mathrm{ft}$ half length

As shown in the figure above, the well with the most number of fracture treatments (9) has the highest cumulative production for a period of 30 years followed by the wells with 5 and 3 fracture treatments respectively with half-length being constant at $600 \mathrm{ft}$. 


\section{Effect of Number of fracture treatments on $4000 \mathrm{ft}$ lateral horizontal well with $900 \mathrm{ft}$ half length}

Figure 23 shows the effect of number of fracture treatments on cumulative natural gas production on a $4000 \mathrm{ft}$ lateral horizontal well when a fracture half length of $900 \mathrm{ft}$ is used

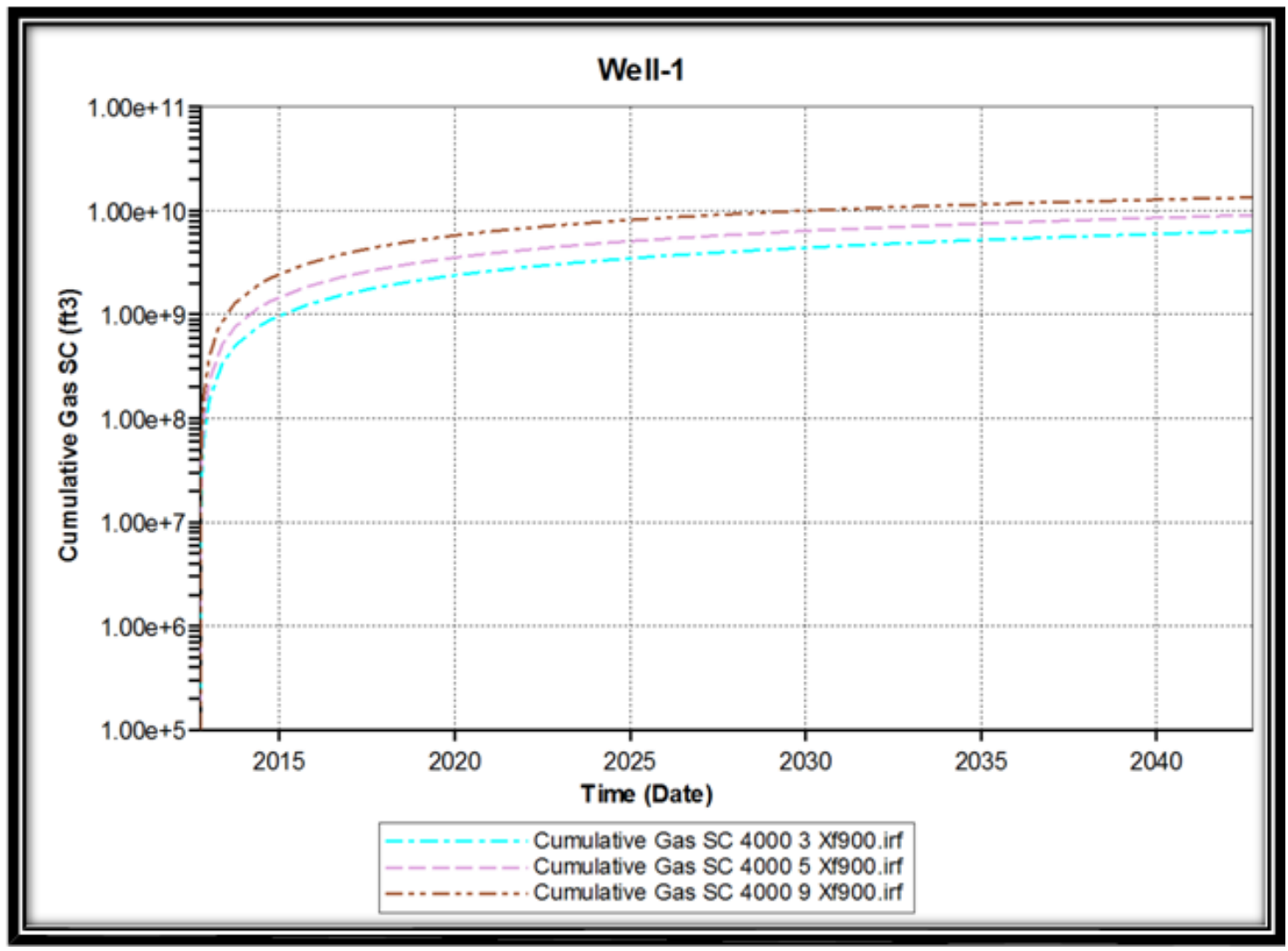

Figure 23: Comparison of cumulative gas production with different Number of fracture treatments on $4000 \mathrm{ft}$ lateral well with $900 \mathrm{ft}$ half length

When the number of treatments increases from fracture from 3 to 5 then to 9 , the cumulative gas production values at the end of 30 years period increases from 6,824,958,464 MMSCF to 9,071,793,152 MMSCF and then to 13,424,247,808 MMSCF respectively. 


\section{Effect of Half-length on $4000 \mathrm{ft}$ lateral horizontal well with 3 fracture treatments}

Figure 24 shows the effect of half-length sizes on cumulative natural gas production on a $4000 \mathrm{ft}$ lateral horizontal well with three fracture treatments.

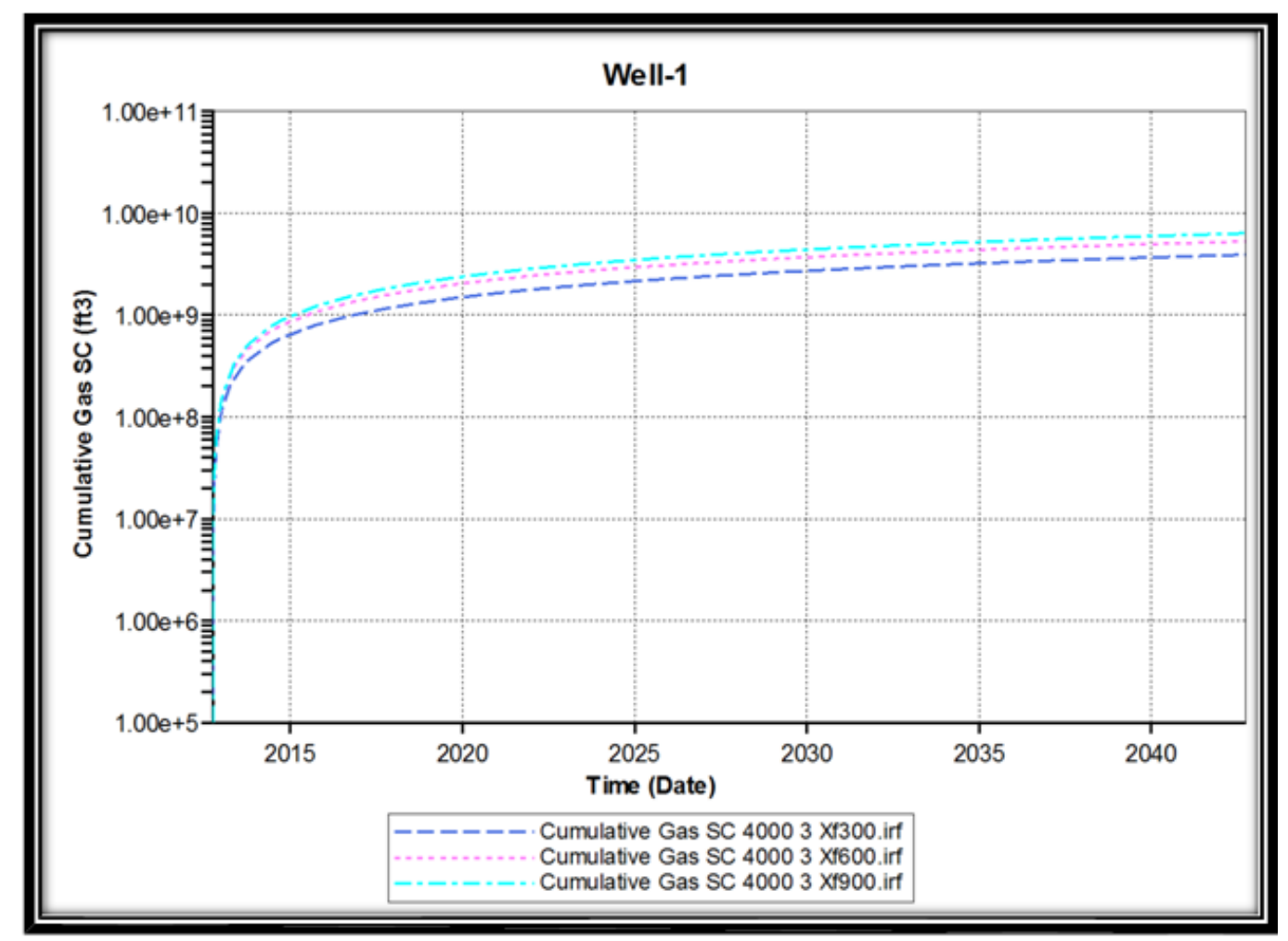

Figure 24: Comparison of cumulative gas production with different Fracture Half Length on $4000 \mathrm{ft}$ Lateral well with 3 fracture treatments

As shown in the figure above, the well with the longest fracture half-length $(900 \mathrm{ft})$ has the highest cumulative production for a period of 30 years followed by the wells with 600 and $300 \mathrm{ft}$ fracture treatments respectively with number of fracture treatment being constant at three. 


\section{Effect of Half-length on $4000 \mathrm{ft}$ lateral horizontal well with $\mathbf{5}$ fracture treatments}

Figure 25 shows the effect of half-length treatment on cumulative natural gas production on a $4000 \mathrm{ft}$ lateral horizontal well with five fracture treatments.

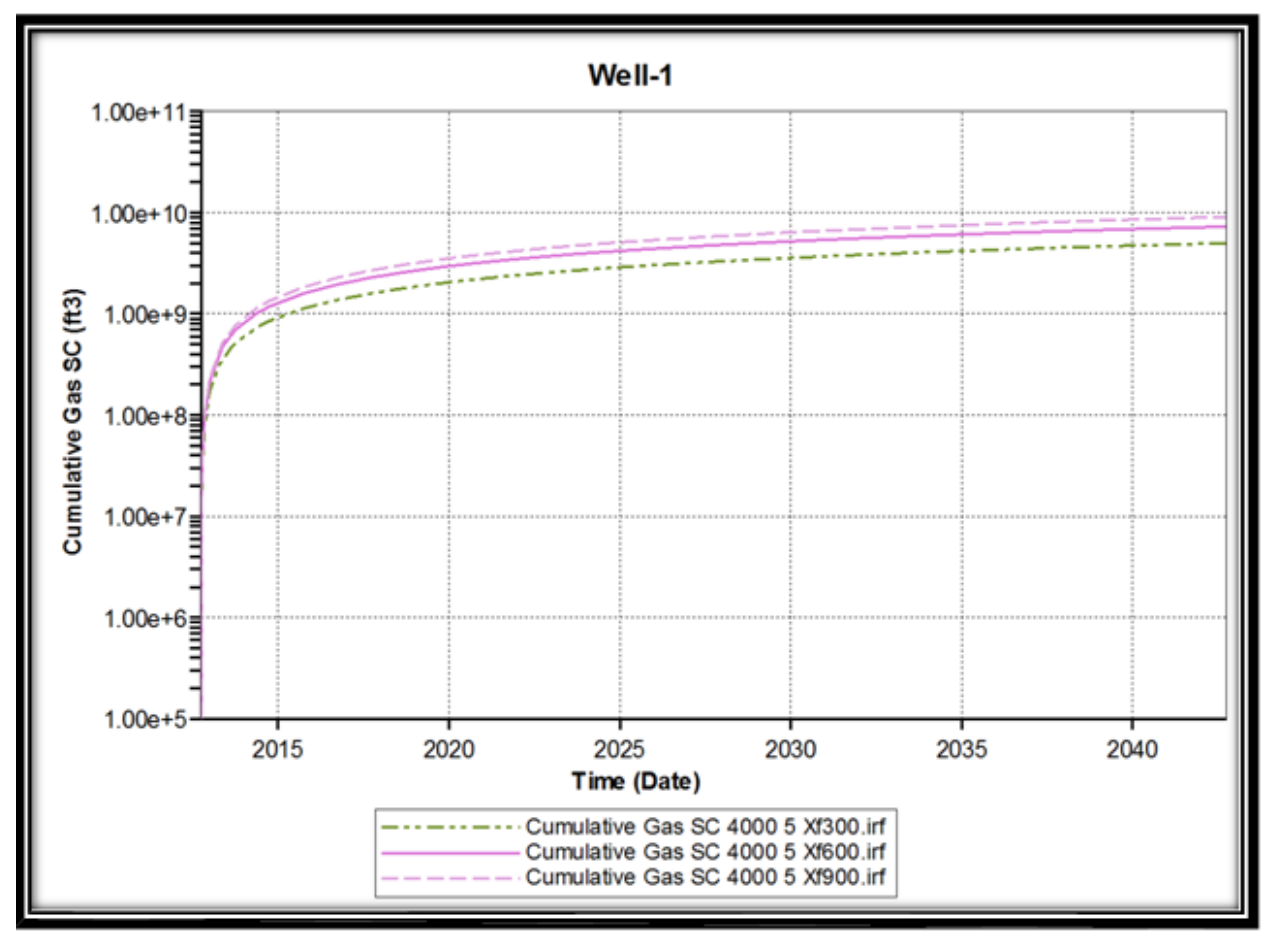

Figure 25: Comparison of cumulative gas production from Effect of Fracture Half Length on $4000 \mathrm{ft}$ Lateral well with 5 fracture treatments

As shown in the figure above, the well with the longest fracture half-length (900 ft) has the highest cumulative production for a period of 30 years followed by the wells with 600 and $300 \mathrm{ft}$ fracture treatments respectively with number of fracture treatment being constant at five. 


\section{Effect of Half-length on $4000 \mathrm{ft}$ lateral horizontal well with 9 fracture treatments}

Figure 26 shows the effect of half-length treatment on cumulative natural gas production on a $4000 \mathrm{ft}$ lateral horizontal well with nine fracture treatments.

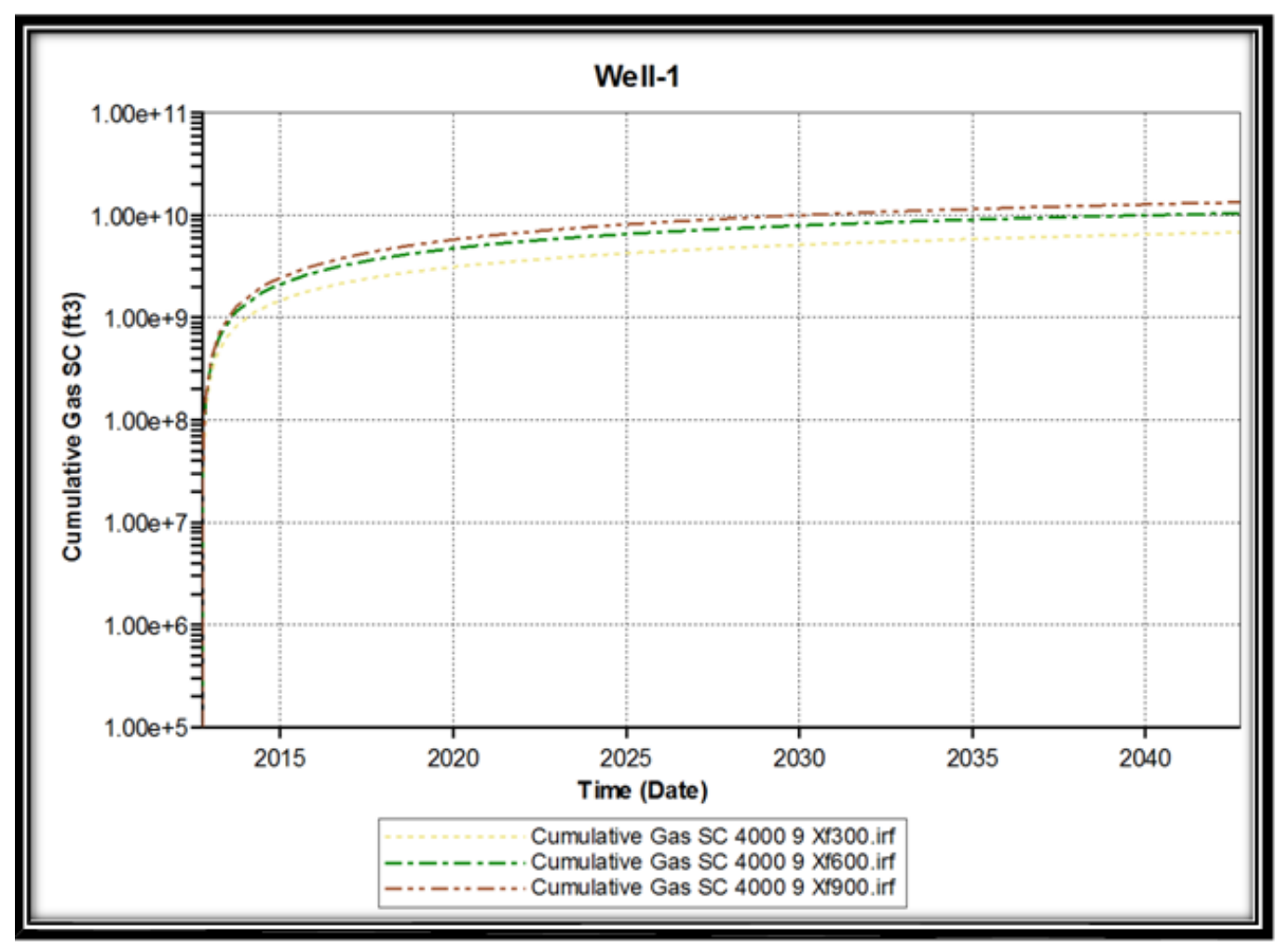

Figure 26: Comparison of cumulative gas production from Effect of Fracture Half Length on $4000 \mathrm{ft}$ Lateral well with 9 fracture treatments

As shown in the figure above, the well with the longest fracture half-length (900 ft) has the highest cumulative production for a period of 30 years followed by the wells with 600 and $300 \mathrm{ft}$ fracture treatments respectively with number of fracture treatment being constant at nine. 


\section{Effect of half-length on $6000 \mathrm{ft}$ lateral horizontal well with 3 fracture treatments}

Figure 27 shows the effect of half-length treatment on cumulative natural gas production on a $6000 \mathrm{ft}$ lateral horizontal well with three fracture treatments.

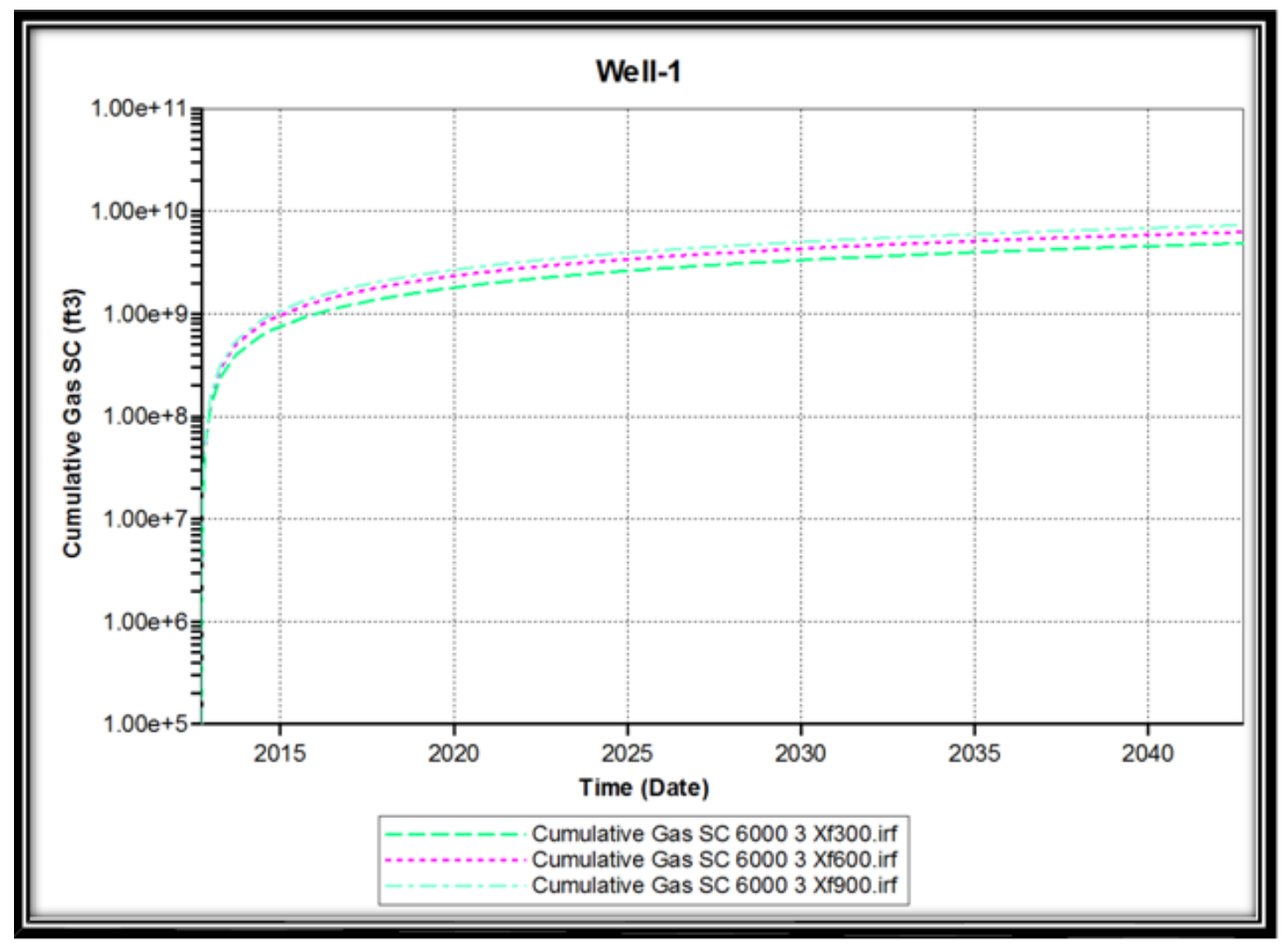

Figure 27: Comparison of cumulative gas production from Effect of Fracture Half Length on $6000 \mathrm{ft}$ Lateral well with 3 fracture treatments

As shown in the figure above, the well with the longest fracture half-length (900 ft) has the highest cumulative production for a period of 30 years followed by the wells with 600 and $300 \mathrm{ft}$ fracture treatments respectively with number of fracture treatment being constant at three. 


\section{Effect of half-length on $6000 \mathrm{ft}$ lateral horizontal well with 5 fracture treatments}

Figure 28 shows the effect of half-length treatment on cumulative natural gas production on a $6000 \mathrm{ft}$ lateral horizontal well with five fracture treatments.

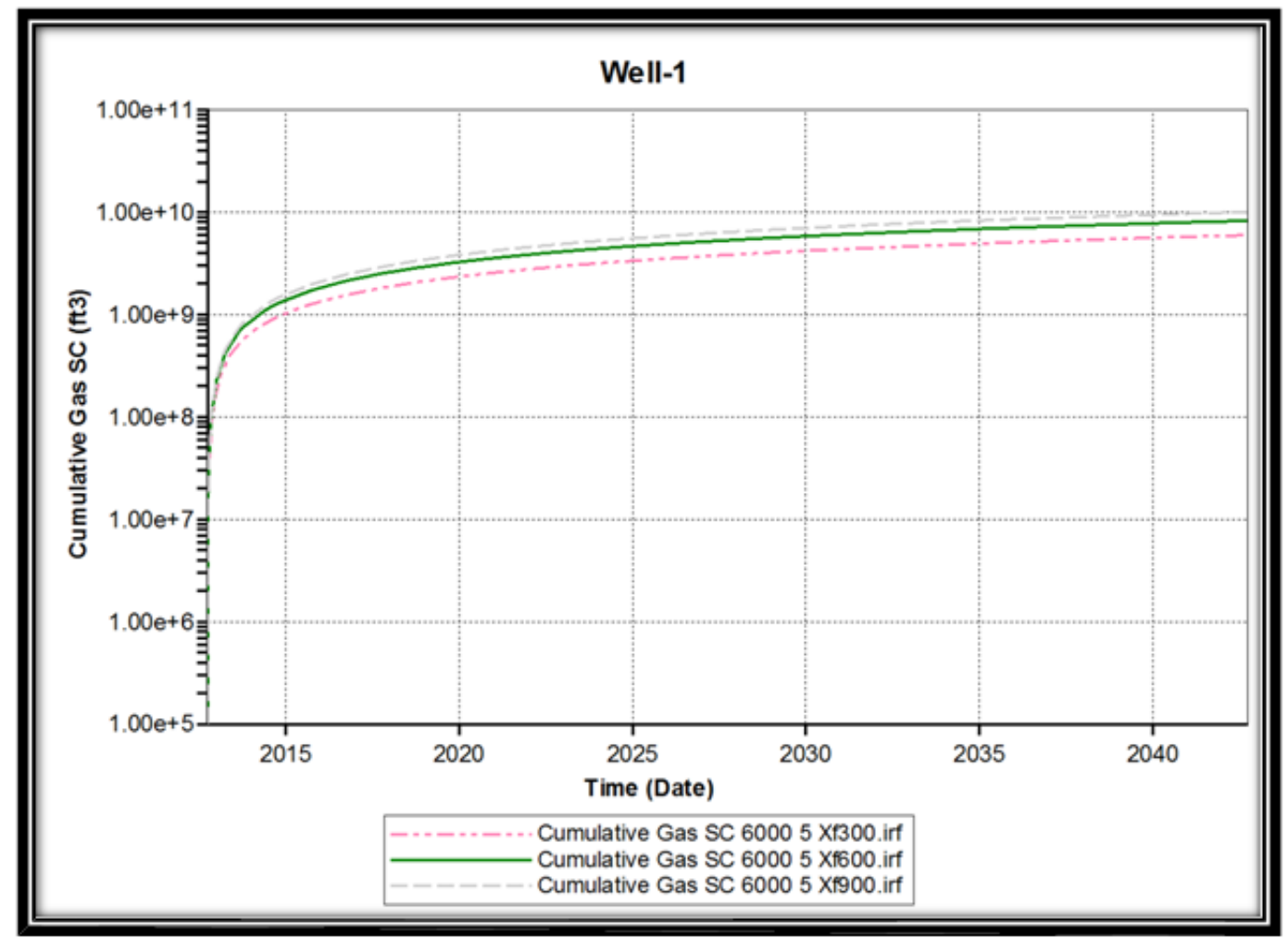

Figure 28: Comparison of cumulative gas production from Effect of Fracture Half Length on $6000 \mathrm{ft}$ Lateral well with 5 fracture treatments

As shown in the figure above, the well with the longest fracture half-length (900ft) has the highest cumulative production for a period of 30 years followed by the wells with 600 and 300ft fracture treatments respectively with number of fracture treatment being constant at five. 


\section{Effect of number of frac treatments on $6000 \mathrm{ft}$ lateral horizontal well with $300 \mathrm{ft}$ half length}

Figure 29 shows the effect of number of fracture treatment on cumulative natural gas production on a $6000 \mathrm{ft}$ lateral horizontal well.

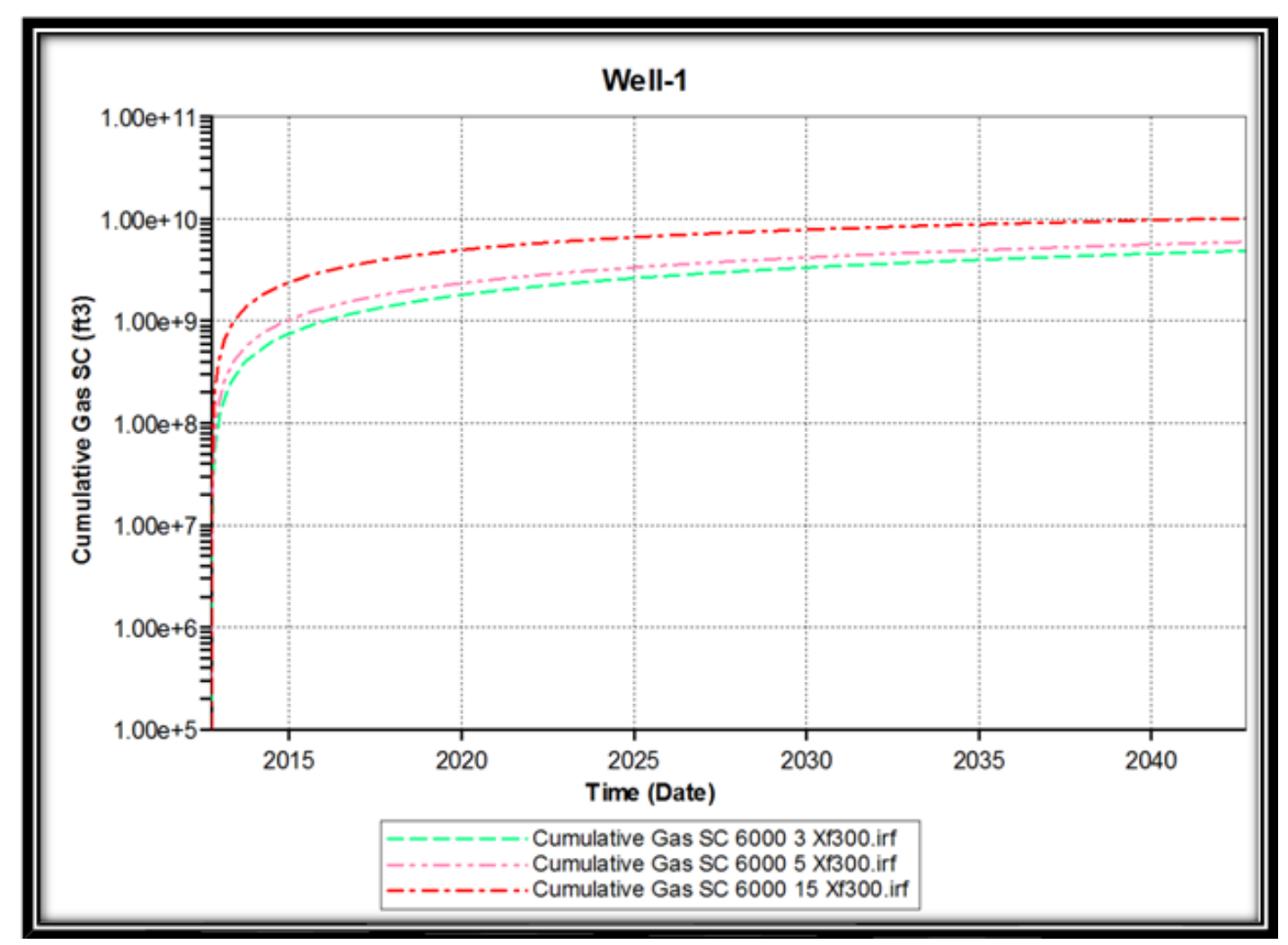

Figure 29: Comparison of cumulative gas production from Effect of Number of fracture treatments on $6000 \mathrm{ft}$ lateral well with $300 \mathrm{ft}$ half length

As shown in the figure above, the well with the most number of fracture treatments (15) has the highest cumulative production for a period of 30 years followed by the wells with 5 and 3 fracture treatments respectively with half-length being constant at $300 \mathrm{ft}$. 


\section{Pressure Distribution}

The pressure distributions at 0, 10, 20 and 30 years are shown in Figures 30, 31, 32 and 33, respectively for a horizontal well with $2000 \mathrm{ft}$ lateral and five $900 \mathrm{ft}$ half-length fracture treatment. Pressure distributions for other well designs used in this study are given in Appendix.

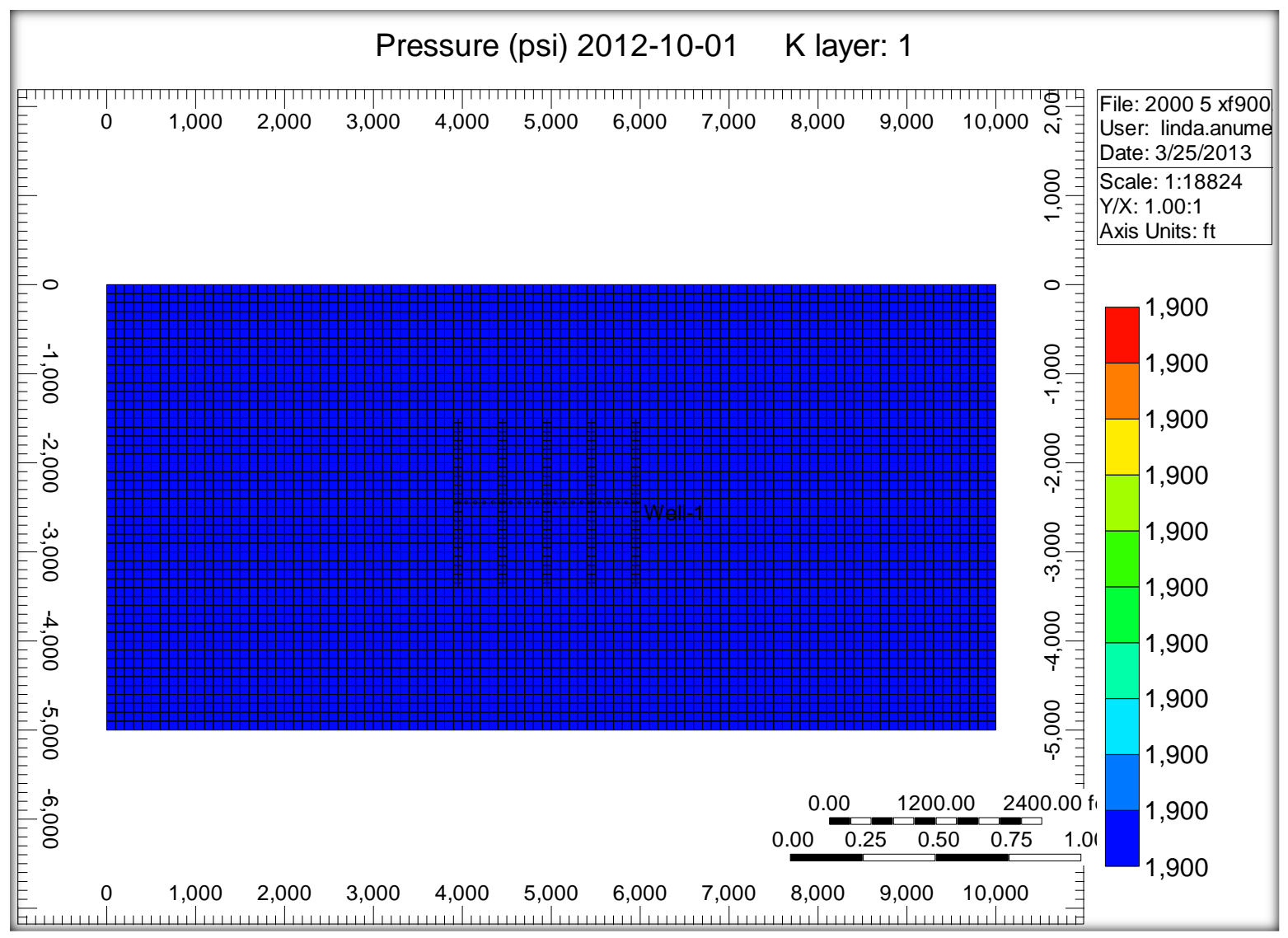

Figure 30: Initial Pressure Distribution 


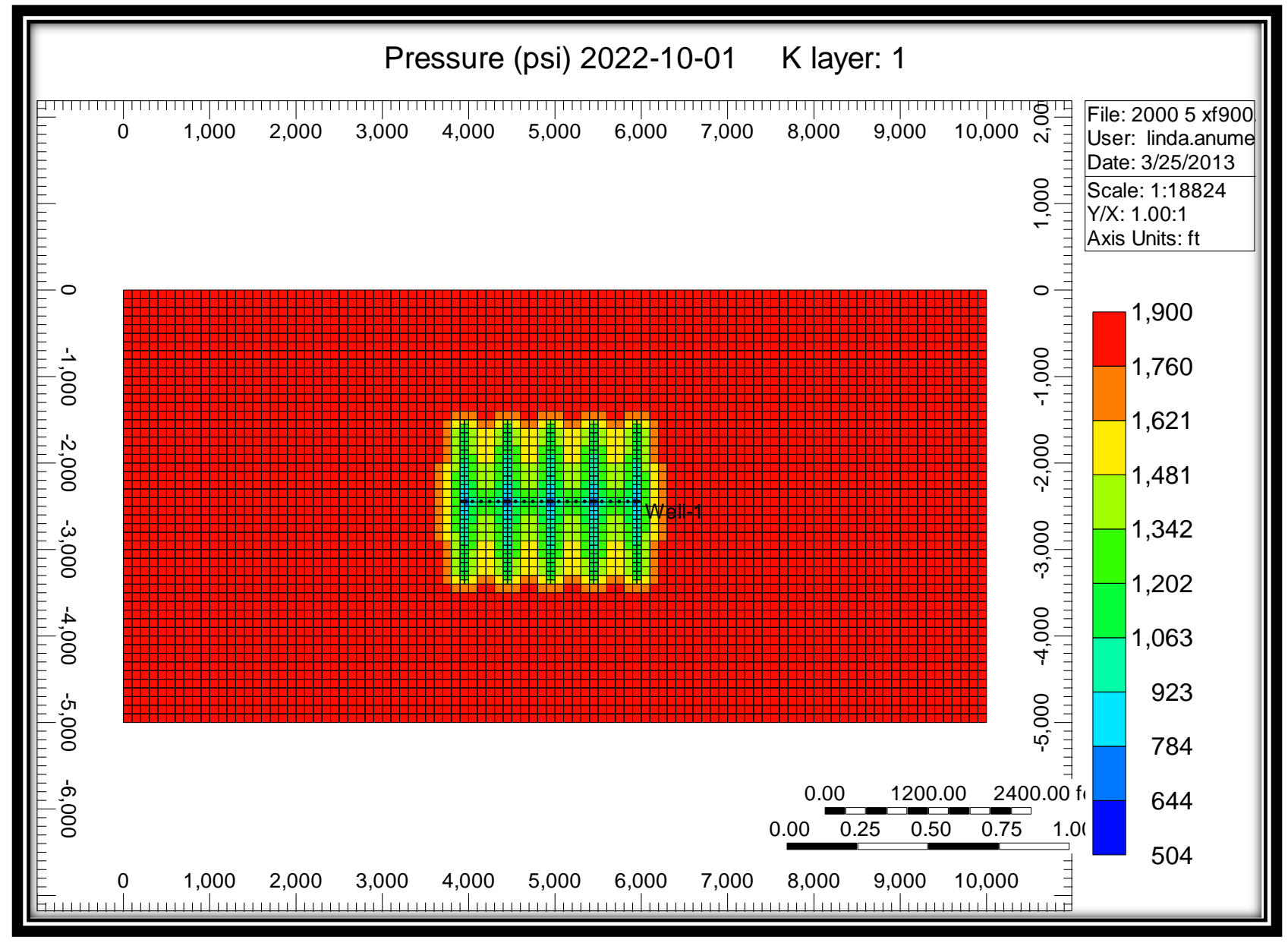

Figure 31: Pressure Distribution after ten years of gas production. 


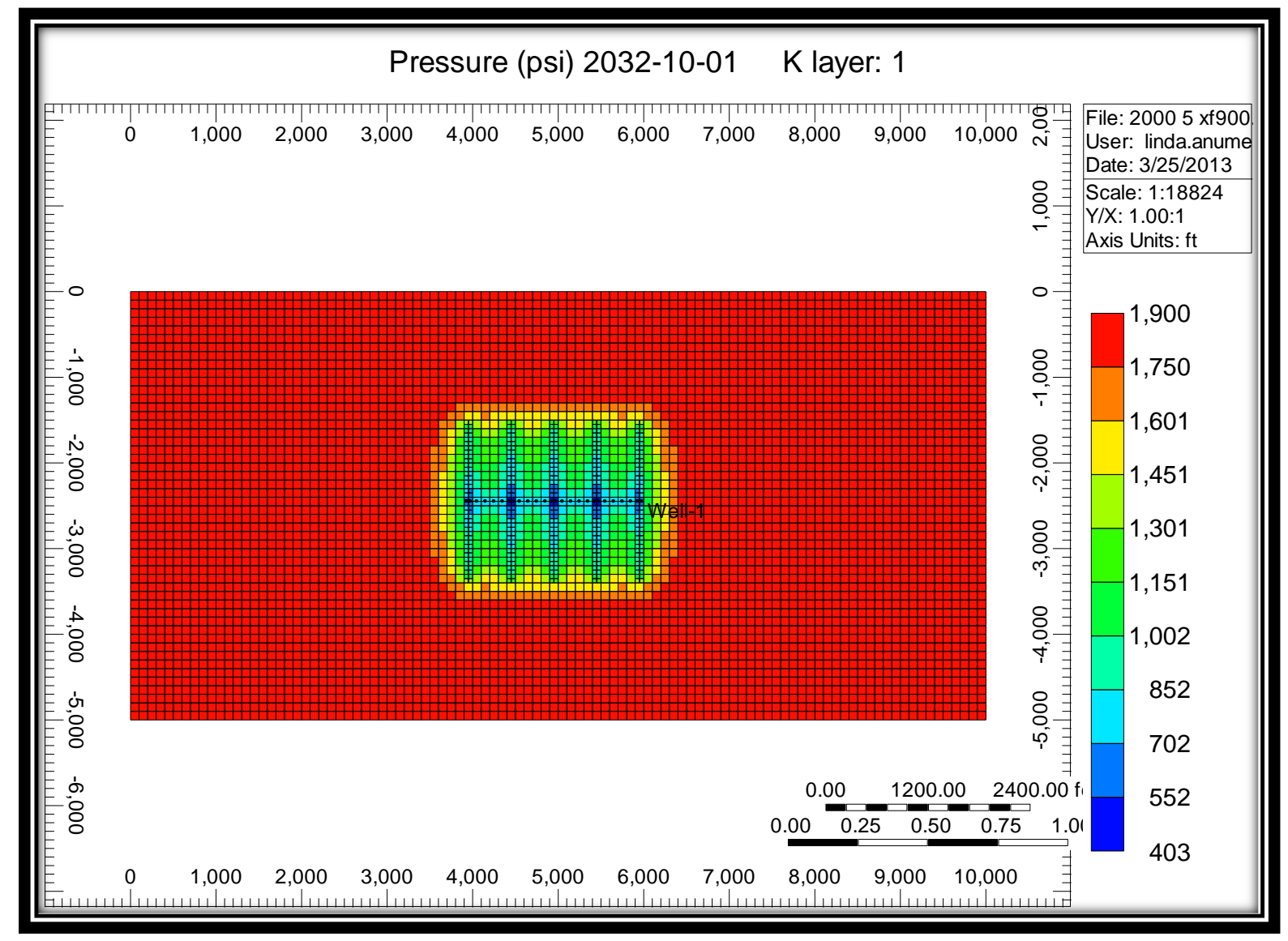

Figure 32: Pressure Distribution after twenty years of gas production. 


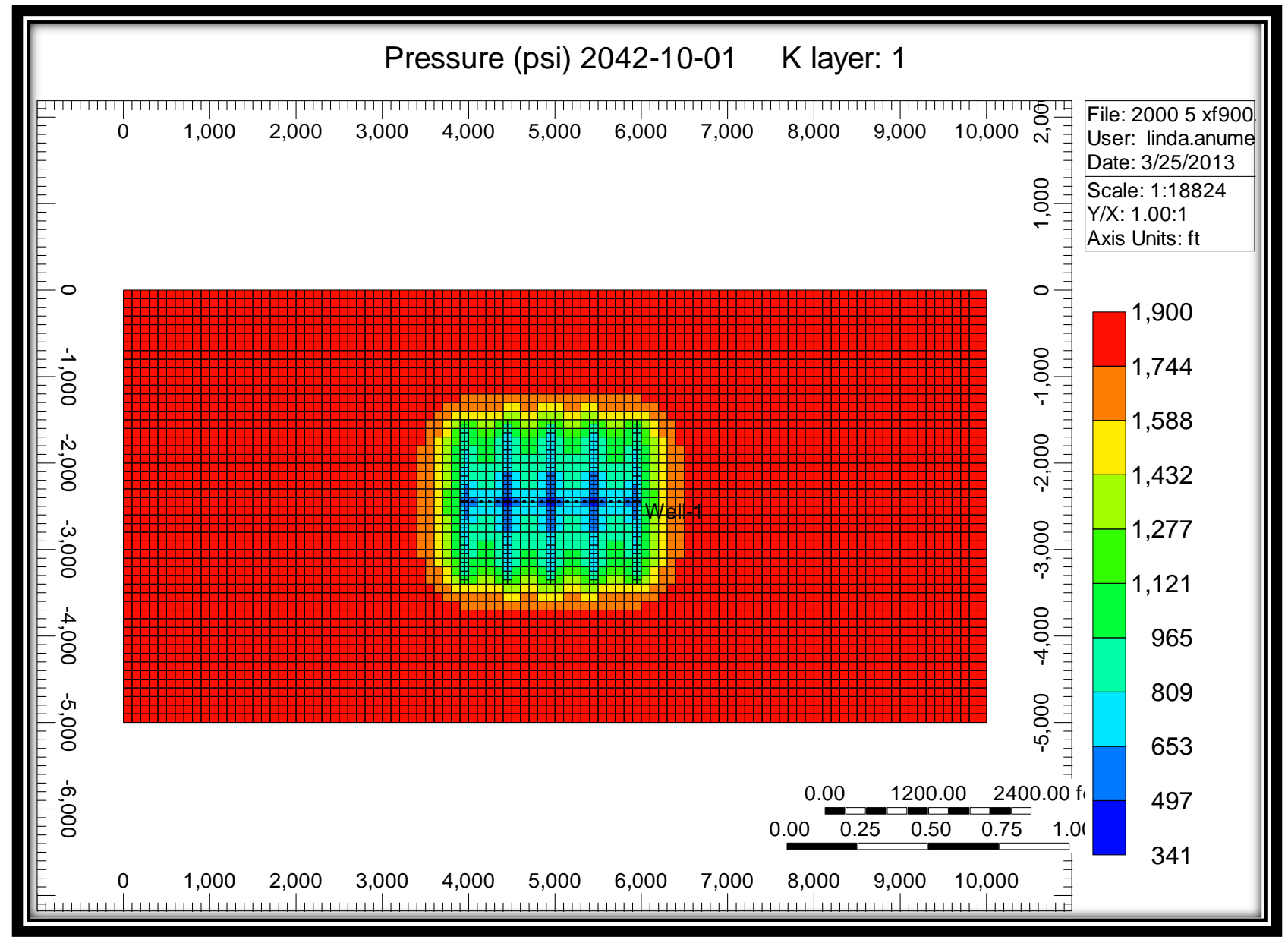

Figure 33: Pressure Distribution after 30 years of gas production. 


\section{Economic Analysis Results}

Table 8 shows the summary of the economic analysis with a gas price of $\$ 3.5 / \mathrm{MSCF}$ for well designs used in this study. The horizontal well with $4000 \mathrm{ft}$ lateral, and fracture half-length of $900 \mathrm{ft}$ with nine fracture treatment was the most economical with an NPV value of $\$ 7,039,826.53$ at the end of 30 years compared to NPV value of $\$ 2,932,917.37$ for a design with a longer lateral length of $6000 \mathrm{ft}$ with 15 fracture treatments. The results show that the effect of fracture half-length has more impact on gas production from the Utica shale based on NPV values. 
Economic Analysis with $\$ 3.5 /$ Mscf

Table 8: Summary of Economic Analysis Price of Gas $=\$ 3.5 /$ Mscf

\begin{tabular}{|c|c|c|c|c|}
\hline \multicolumn{5}{|c|}{ Gas Price $=\$ 3.5 / \mathrm{MSCF}$} \\
\hline Lateral length, $\mathrm{ft}$ & Number of treatments & Fracture half length,ft & Total NPV, \$ & AVG ROR, $\%$ \\
\hline 2000 & 0 & 0 & -1313110.822 & -43.77 \\
\hline 2000 & 3 & 300 & -559701.1245 & -16.51 \\
\hline 2000 & 3 & 600 & $649,096.81$ & 18.41 \\
\hline 2000 & 3 & 900 & $1,388,293.53$ & 37.93 \\
\hline 2000 & 5 & 300 & $450,606.55$ & 12.35 \\
\hline 2000 & 5 & 600 & $2,410,458.97$ & 62.21 \\
\hline 2000 & 5 & 900 & $3,618,444.86$ & 88.25 \\
\hline 2000 & 10 & 300 & $1,736,143.60$ & 40.38 \\
\hline 2000 & 10 & 600 & $4,778,157.30$ & 90.59 \\
\hline 4000 & 0 & 0 & -1633070.837 & -32.66 \\
\hline 4000 & 3 & 300 & -1735570.464 & -32.20 \\
\hline 4000 & 3 & 600 & -526320.9004 & -9.53 \\
\hline 4000 & 3 & 900 & $213,180.09$ & 3.77 \\
\hline 4000 & 5 & 300 & -669702.5101 & -11.85 \\
\hline 4000 & 5 & 600 & $1,345,811.67$ & 22.91 \\
\hline 4000 & 5 & 900 & $2,582,285.00$ & 42.33 \\
\hline 4000 & 9 & 300 & $75,192.44$ & 1.08 \\
\hline 4000 & 9 & 600 & $4,868,368.69$ & 74.04 \\
\hline 4000 & 9 & 900 & $7,039,826.53$ & 100.86 \\
\hline 4000 & 20 & 300 & $4,342,500.75$ & 57.14 \\
\hline 6000 & 0 & 0 & -2037433.61 & -29.11 \\
\hline 6000 & 3 & 300 & -3350292.899 & -45.34 \\
\hline 6000 & 3 & 600 & -2261986.501 & -30.06 \\
\hline 6000 & 3 & 900 & -1005694 & -13.13 \\
\hline 6000 & 5 & 300 & -995694 & -13.02 \\
\hline 6000 & 5 & 600 & $129,429.50$ & 1.64 \\
\hline 6000 & 5 & 900 & $1,364,679.00$ & 16.85 \\
\hline 6000 & 15 & 300 & $2,932,917.37$ & 32.77 \\
\hline
\end{tabular}


Figure 34 compares NPV obtained for each well and fracture design at a gas price of \$3.5/MSCF. The well with $4000 \mathrm{ft}$ lateral, $900 \mathrm{ft}$ of fracture half-length and nine fracture treatments appears to have the highest NPV. There were 17 designs with positive NPV while 11 designs yielded negative NPV values.

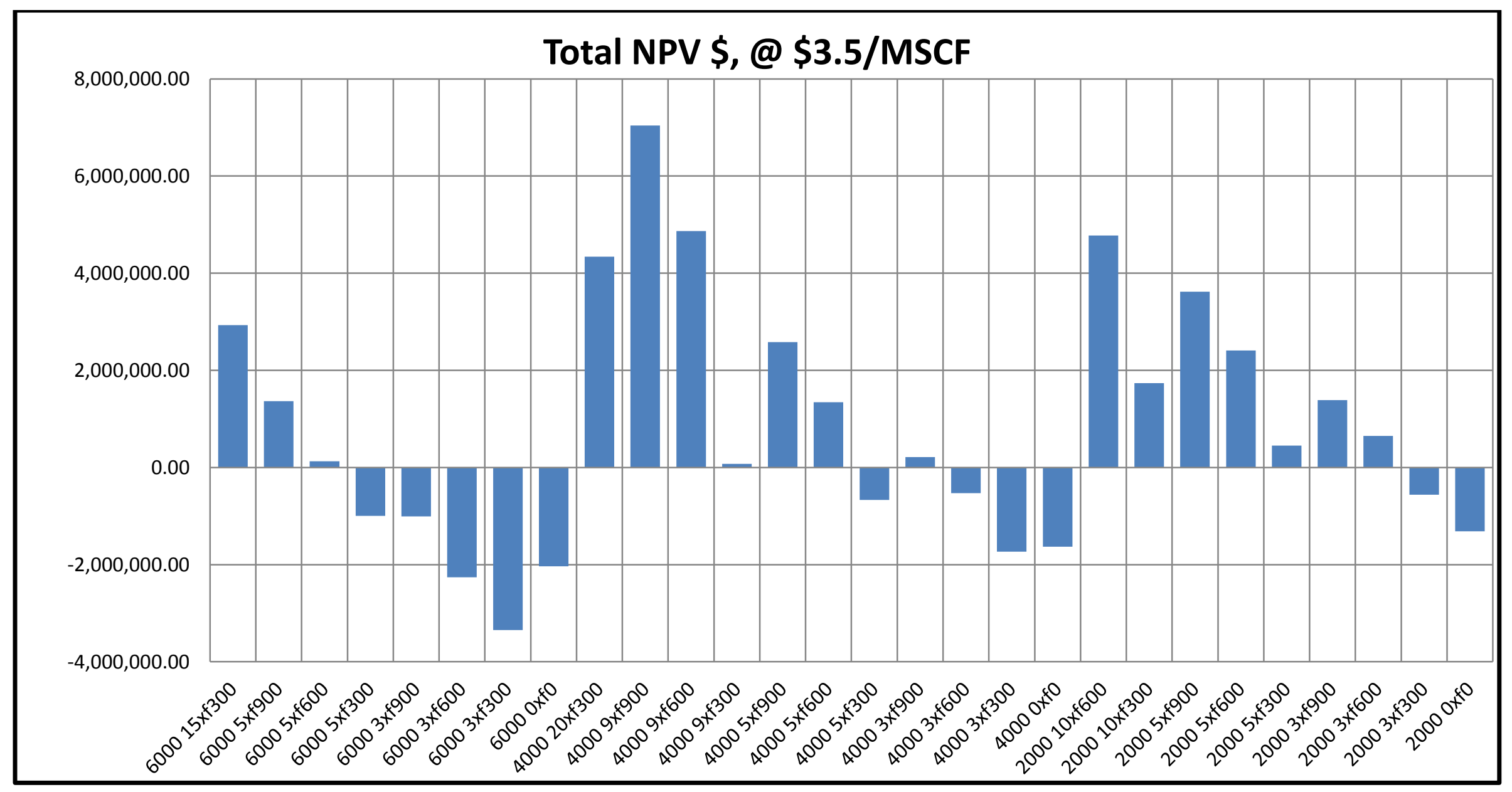

Figure 34: NPV by well design at \$3.5/Mscf gas price 
Figure 35 lists Rate of Return (ROR) values by well and fracture design at a gas price of \$3.5/Mscf. The wells with $4000 \mathrm{ft}$ lateral and $900 \mathrm{ft}$ of fracture half-length and nine fracture treatments has the highest rate of return of $100 \%$ over a period of 30 years.

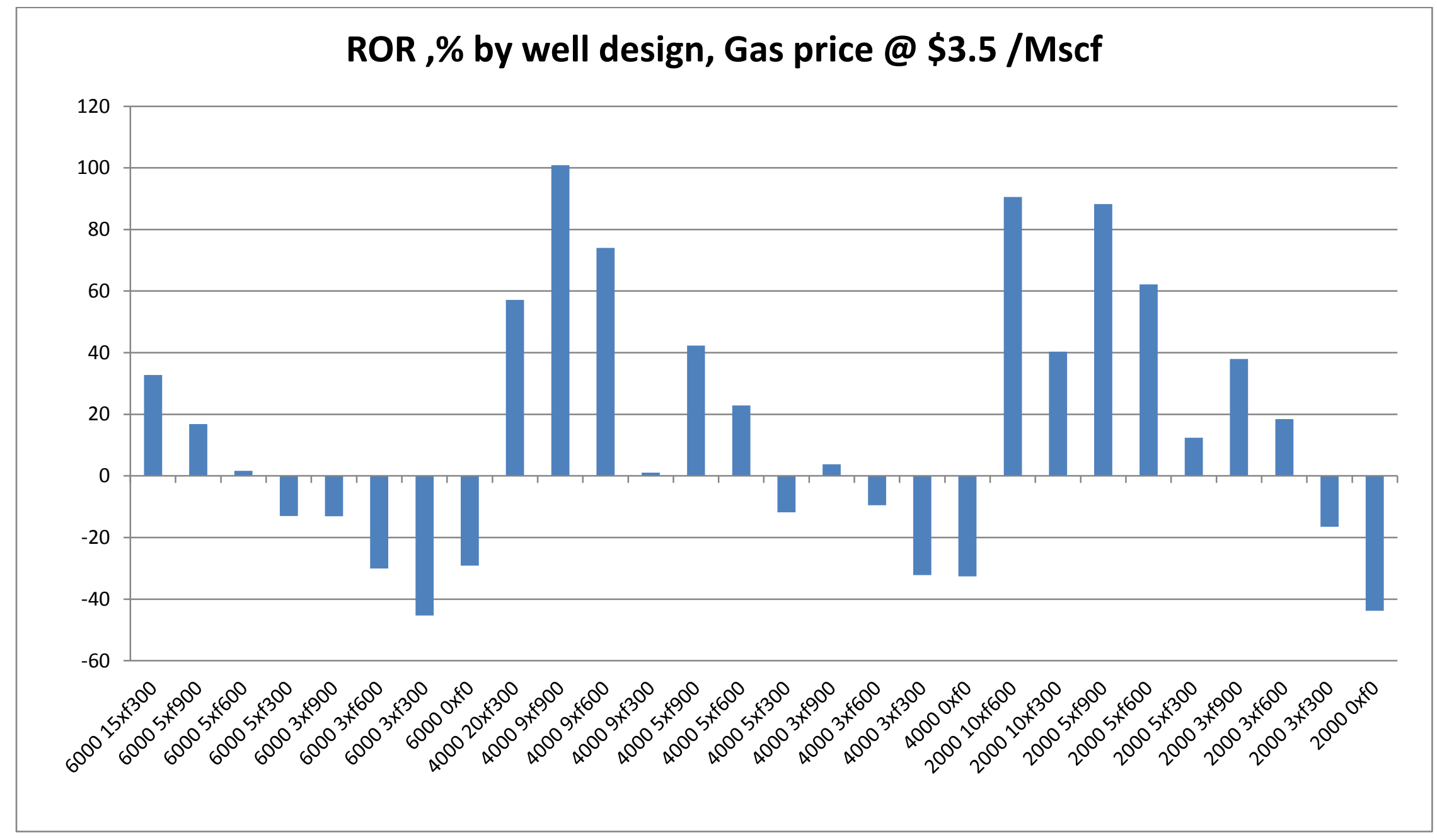

Figure 35: Rate of Return by well design at \$3.5/Mscf gas price 


\section{Economic Analysis with \$4/Mscf}

Table 9 summarizes the economic analysis with a gas price of $\$ 4 / \mathrm{MSCF}$ for well designs used in this study. The horizontal well with $4000 \mathrm{ft}$ lateral, and fracture half-length of $900 \mathrm{ft}$ with nine fracture treatment was the most economical with an NPV value of $\$ 9,060,668.44$ at the end of 30 years compared to NPV value of $\$ 4,648,486.54$ for a design with a longer lateral length of 6000 $\mathrm{ft}$ with 15 fracture treatments. The results show that the effect of fracture half-length has more impact on gas production from the Utica shale based on NPV values. 
Table 9: Summary of Economic Analysis Price of Gas = \$4/Mscf

\begin{tabular}{|c|c|c|c|c|}
\hline \multicolumn{5}{|c|}{ Gas Price $=\$ 3.5 / \mathrm{MSCF}$} \\
\hline Lateral length, $\mathrm{ft}$ & $\begin{array}{l}\text { Number of } \\
\text { treatments }\end{array}$ & Fracture half length, $\mathrm{ft}$ & Total NPV, \$ & AVG ROR, \% \\
\hline 2000 & 0 & 0 & -1054117.109 & -35.14 \\
\hline 2000 & 3 & 300 & -137363.1696 & -4.05 \\
\hline 2000 & 3 & 600 & $1,263,405.90$ & 35.84 \\
\hline 2000 & 3 & 900 & $2,127,487.86$ & 58.13 \\
\hline 2000 & 5 & 300 & $1,054,417.03$ & 28.89 \\
\hline 2000 & 5 & 600 & $3,326,391.23$ & 85.84 \\
\hline 2000 & 5 & 900 & $4,739,089.38$ & 115.59 \\
\hline 2000 & 10 & 300 & $2,616,459.37$ & 60.85 \\
\hline 2000 & 10 & 600 & $6,157,332.18$ & 100.63 \\
\hline 4000 & 0 & 0 & -1134071.413 & -22.68 \\
\hline 4000 & 3 & 300 & -1195499.558 & -4.05 \\
\hline 4000 & 3 & 600 & 205785.66 & 3.72 \\
\hline 4000 & 3 & 900 & $1,070,215.36$ & 18.91 \\
\hline 4000 & 5 & 300 & 59778.1 & 1.06 \\
\hline 4000 & 5 & 600 & $2,394,612.48$ & 40.76 \\
\hline 4000 & 5 & 900 & $3,840,621.00$ & 62.96 \\
\hline 4000 & 9 & 300 & $1,101,086.62$ & 15.77 \\
\hline 4000 & 9 & 600 & $6,521,145.19$ & 99.18 \\
\hline 4000 & 9 & 900 & $9,060,668.44$ & 129.81 \\
\hline 4000 & 20 & 300 & $6,066,581.83$ & 79.82 \\
\hline 6000 & 0 & 0 & -1310486.01 & -18.72 \\
\hline 6000 & 3 & 300 & -2755182.341 & -37.28 \\
\hline 6000 & 3 & 600 & -1492117.885 & -19.83 \\
\hline 6000 & 3 & 900 & -37069.5 & -0.48 \\
\hline 6000 & 5 & 300 & -27069.5 & -0.35 \\
\hline 6000 & 5 & 600 & $1,290,929.00$ & 16.39 \\
\hline 6000 & 5 & 900 & $2,734,785.00$ & 33.76 \\
\hline 6000 & 15 & 300 & $4,648,486.54$ & 51.94 \\
\hline
\end{tabular}


Figure 36 shows NPV values by well and fracture design at a gas price of \$4/Mscf. There were 19 designs with positive NPV while nine designs with negative NPV values.

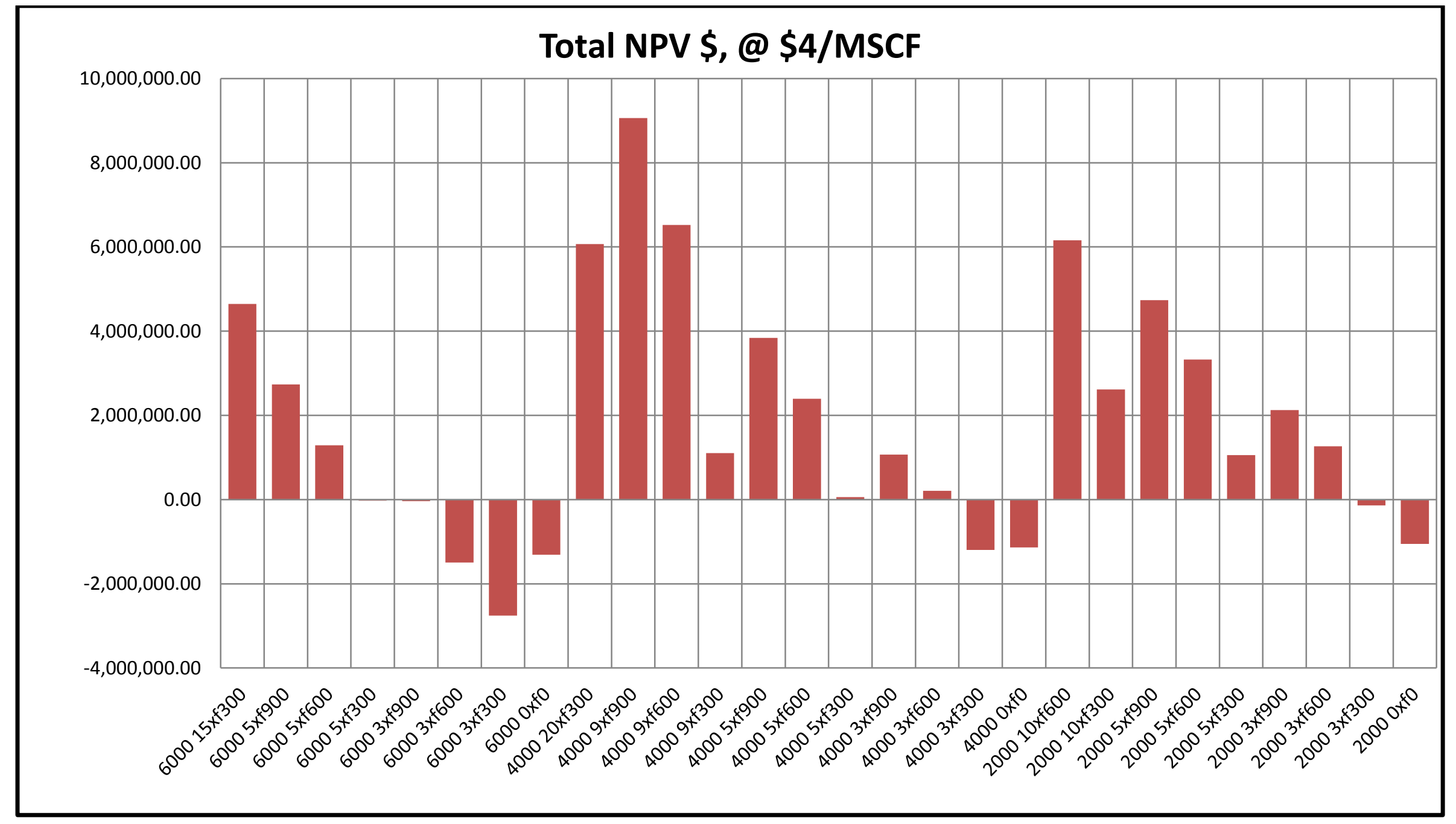

Figure 36: NPV by well design at \$4/Mscf gas price 
Figure 37 compares Rate of Return values by well and fracture design at a gas price of $\$ 4 / \mathrm{Mscf}$. ROR values range between 5\% and $129.8 \%$.

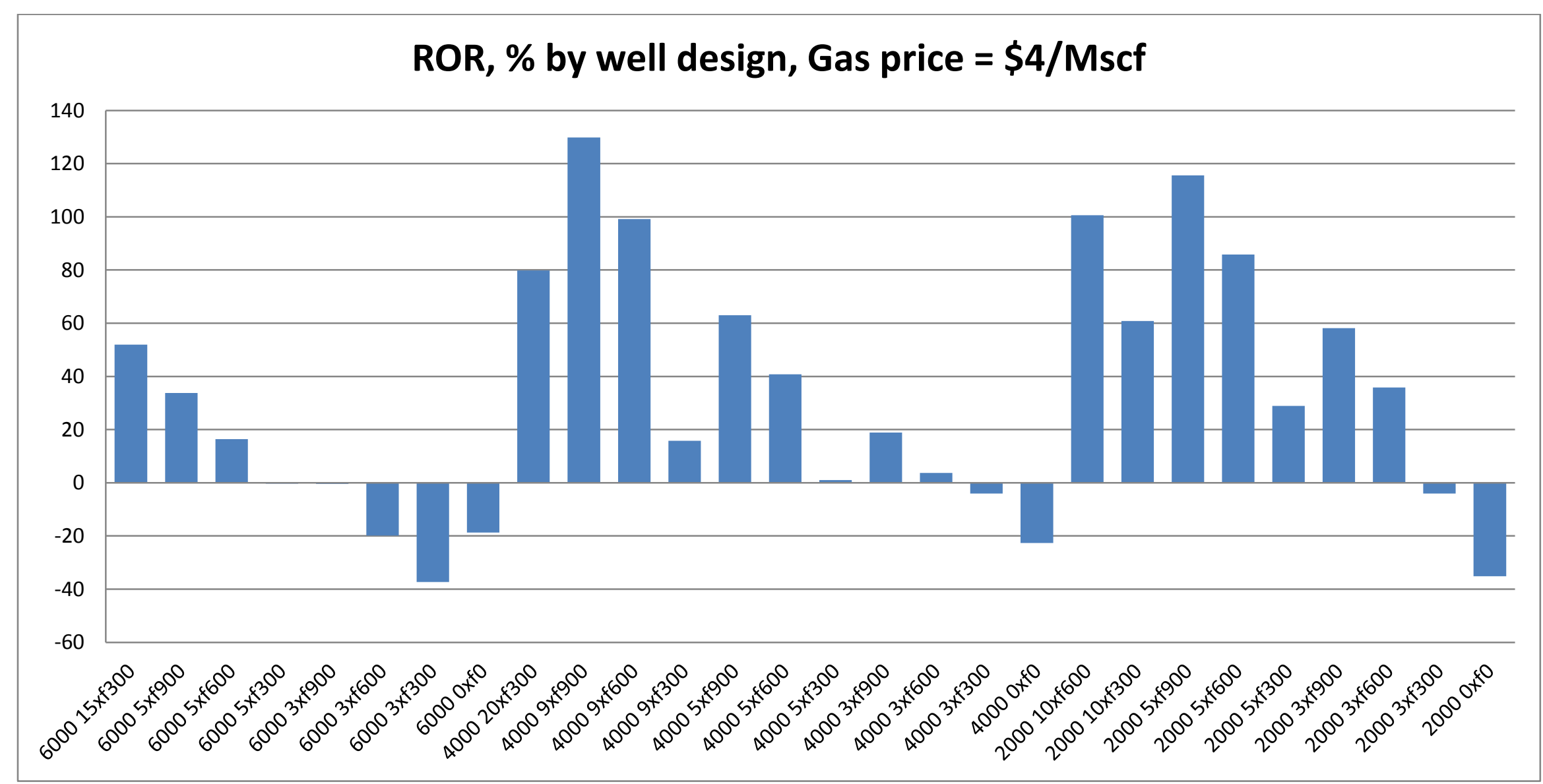

Figure 37: Rate of Return by well design at \$4/Mscf gas price 
Based on the results of the NPV values above, when the price of gas used in the economic analysis is increased from $\$ 3.50$ to $\$ 4.0$ per MSCF, two cases or designs become economical while they were uneconomical with $\$ 3.5 / \mathrm{Mscf}$. These two designs are $4000 \mathrm{ft}$ lateral length with 3 fracture treatments and 600 half-length and $4000 \mathrm{ft}$ lateral length with 5 fracture treatment and 300 half length.

\section{Economic Analysis with \$5/Mscf}

Table 10 summarizes the economic analysis with a gas price of $\$ 5 / \mathrm{MSCF}$ for well designs used in this study. The horizontal well with $4000 \mathrm{ft}$ lateral, and fracture half-length of $900 \mathrm{ft}$ with nine fracture treatment was the most economical with an NPV value of $\$ 13,102,352.25$ at the end of 30 years compared to NPV value of $\$ 8,079,624.88$ for a design with a longer lateral length of $6000 \mathrm{ft}$ with 15 fracture treatments. 
Table 10: Summary of Economic Analysis Price of Gas $=\$ 5 /$ Mscf

\begin{tabular}{|c|c|c|c|c|}
\hline \multicolumn{5}{|c|}{ Gas Price $=\$ 5 / \mathrm{MSCF}$} \\
\hline Lateral length, $\mathrm{ft}$ & Number of treatments & Fracture half length,ft & Total NPV, \$ & AVG ROR, \% \\
\hline 2000 & 0 & 0 & -536129.6844 & -17.87 \\
\hline 2000 & 3 & 300 & 707312.74 & 20.86 \\
\hline 2000 & 3 & 600 & $2,492,024.08$ & 70.70 \\
\hline 2000 & 3 & 900 & $3,605,876.53$ & 98.52 \\
\hline 2000 & 5 & 300 & $2,262,037.98$ & 61.97 \\
\hline 2000 & 5 & 600 & $5,158,255.74$ & 133.12 \\
\hline 2000 & 5 & 900 & $6,980,378.43$ & 165.25 \\
\hline 2000 & 10 & 300 & $4,377,090.92$ & 101.79 \\
\hline 2000 & 10 & 600 & $8,915,681.92$ & 170.70 \\
\hline 4000 & 0 & 0 & -136072.5639 & -2.72 \\
\hline 4000 & 3 & 300 & -115357.7451 & -2.14 \\
\hline 4000 & 3 & 600 & 1669998.78 & 30.23 \\
\hline 4000 & 3 & 900 & $2,784,285.90$ & 49.19 \\
\hline 4000 & 5 & 300 & 1518739.33 & 26.88 \\
\hline 4000 & 5 & 600 & $4,492,214.10$ & 76.46 \\
\hline 4000 & 5 & 900 & $6,357,293.00$ & 104.22 \\
\hline 4000 & 9 & 300 & $3,152,874.98$ & 45.17 \\
\hline 4000 & 9 & 600 & $9,826,698.19$ & 149.46 \\
\hline 4000 & 9 & 900 & $13,102,352.25$ & 187.71 \\
\hline 4000 & 20 & 300 & $9,514,743.99$ & 125.19 \\
\hline 6000 & 0 & 0 & 143409.19 & 2.05 \\
\hline 6000 & 3 & 300 & -1564961.224 & 2.05 \\
\hline 6000 & 3 & 600 & 47619.35 & 0.63 \\
\hline 6000 & 3 & 900 & 1900180 & 24.81 \\
\hline 6000 & 5 & 300 & 1910180 & 24.97 \\
\hline 6000 & 5 & 600 & $3,613,928.00$ & 45.89 \\
\hline 6000 & 5 & 900 & $5,474,998.00$ & 67.59 \\
\hline 6000 & 15 & 300 & $8,079,624.88$ & 90.28 \\
\hline
\end{tabular}


Figure 38 compares NPV obtained for each well and fracture design at a gas price of \$5/Mscf. The well with $4000 \mathrm{ft}$ lateral, $900 \mathrm{ft}$ of fracture half-length and nine fracture treatments appears to have the highest NPV. There were 24 designs with positive NPV while 4 designs yielded negative NPV values.

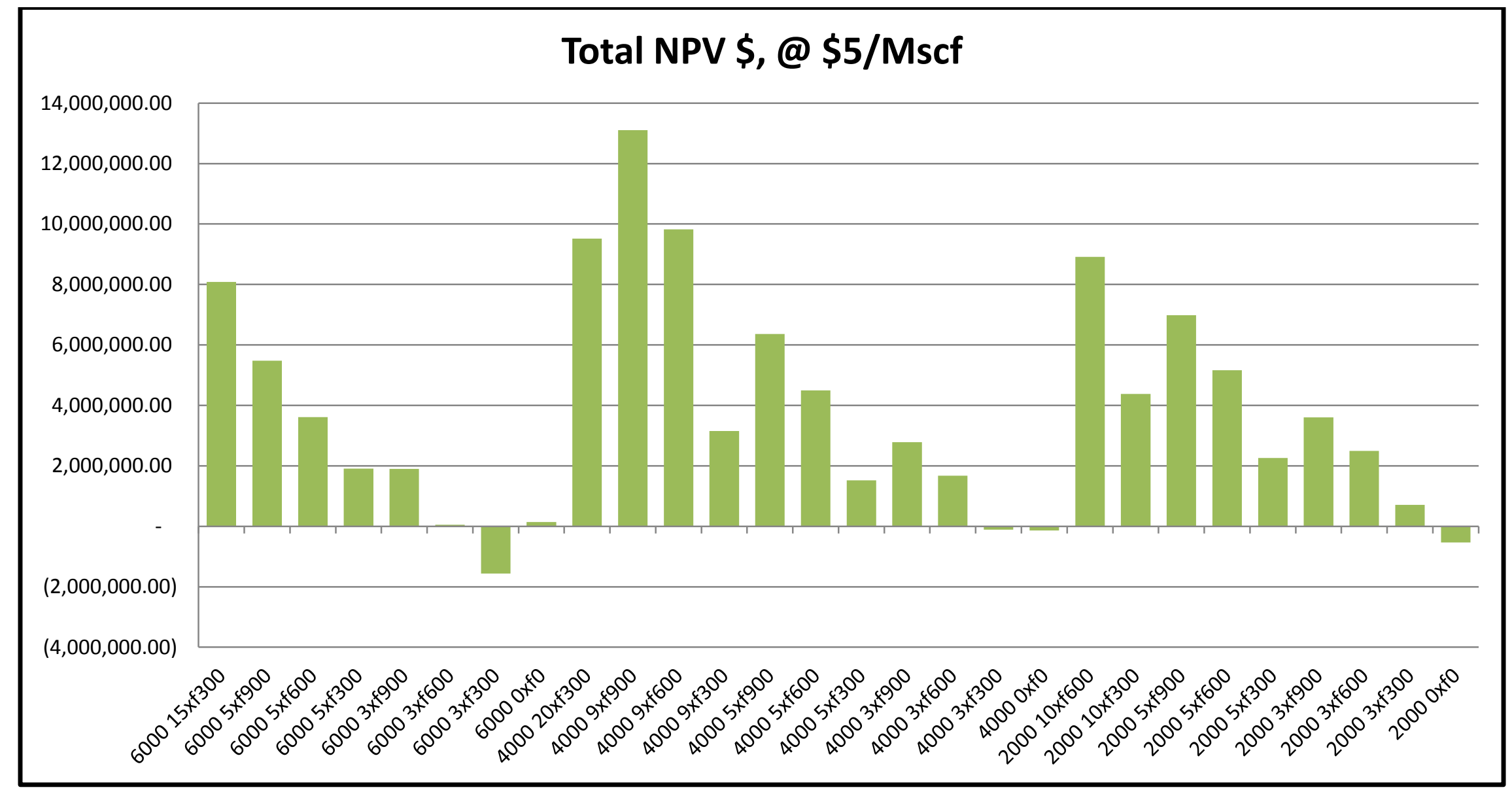

Figure 38: NPV by well design at \$5/Mscf gas price 
Figure 39 compares Rate of Return values by well and fracture design at a gas price of $\$ 5 /$ Mscf. ROR values range between $2 \%$ and $188 \%$.

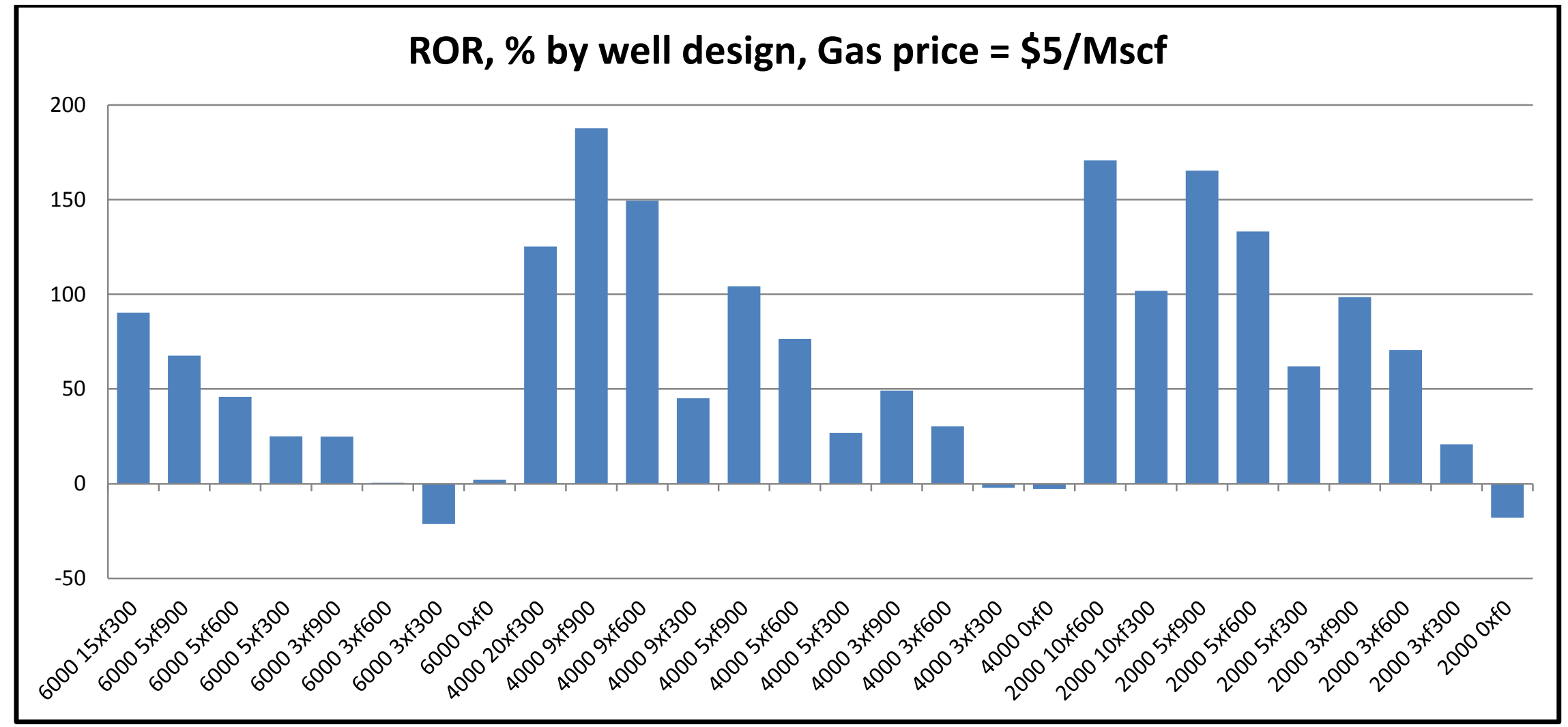

Figure 39: Rate of Return by well design at \$5/Mscf gas price

Based on the results of the NPV values above, when the price of gas used in this study is increased from $\$ 4.0$ to $\$ 5.0$ per MSCF, five cases or designs become economical while they were uneconomical with \$4.0/Mscf. 


\section{Summary of Economic Analysis}

Figure 40 compares the NPV values for each well design used in this study for three different gas prices, namely $\$ 3.5$, $\$ 4$ and $\$ 5$ per MSCF. There were two designs that became economical at $\$ 4 / M S C F$. With further price increase to \$5/MSCF three additional designs became economically attractive.

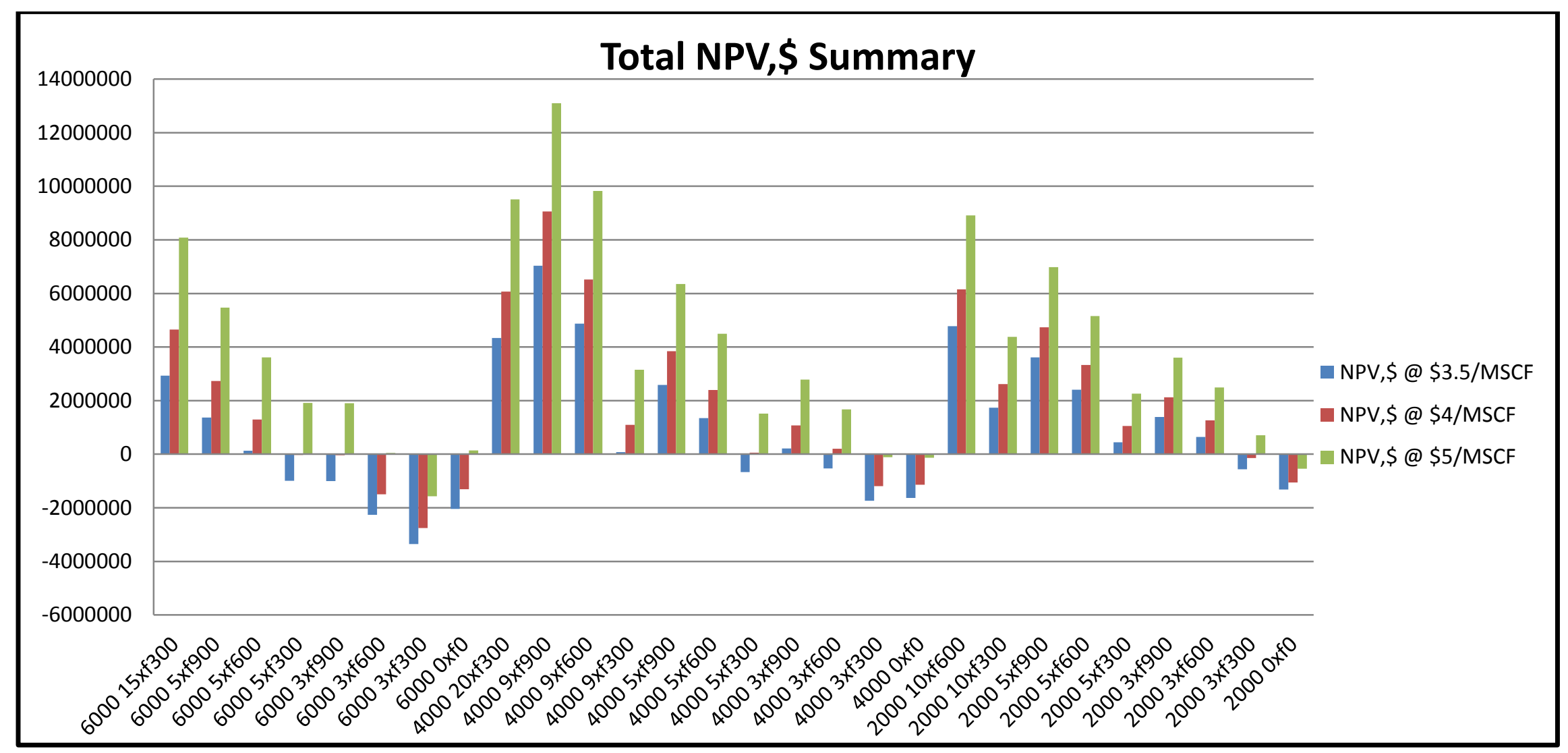

Figure 40: NPV by well design at \$3.5/Mscf, $\$ 4 /$ Mscf and $\$ 5 /$ Mscf gas price 
Figure 41 compares the Rate of Return values for each well design used in this study with three price scenarios.

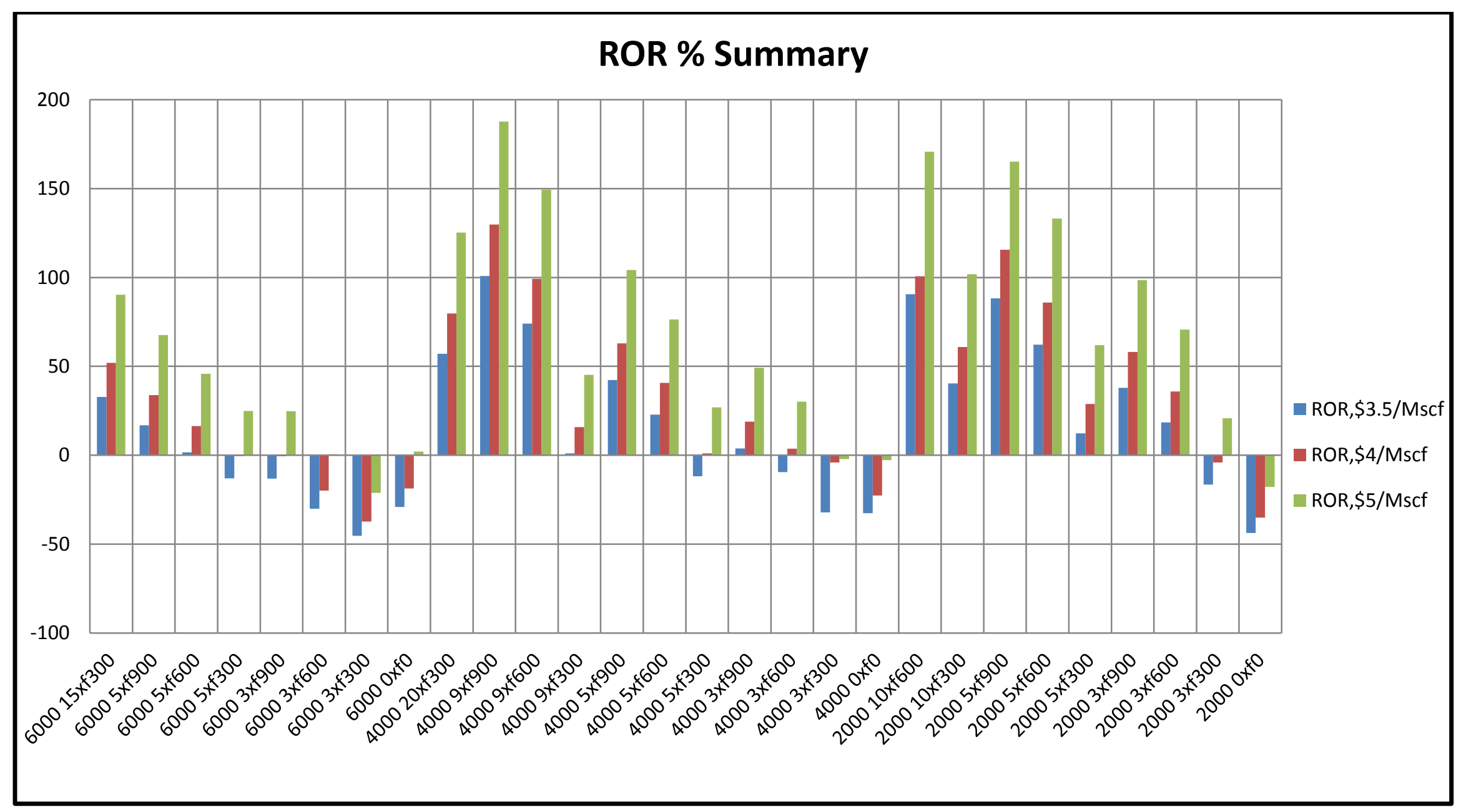

Figure 41: Rate of Return by well design at \$3.5/Mscf, \$4/Mscf and \$5/Mscf gas price 
From figure 40 , it is clear that at $\$ 5$ per MSCF of gas, all well designs appear to have a higher NPV than at $\$ 3.5$ and $\$ 4$ per MSCF of gas. However, even $\$ 5 / \mathrm{MSCF}$ is not economical alternative when some of the well designs are considered in this study. 


\section{Chapter VI- Conclusion}

In this research, modeling studies were conducted for the purpose to understand the impact of design parameters such as lateral length of horizontal wells, fracture half lengths and number of fracture treatments on natural gas production from the Utica shale. A total of 28 cases with different designs were considered in this study.

Based on the runs conducted in this study, the horizontal well design with a lateral length of $4000 \mathrm{ft}$ and $900 \mathrm{ft}$ fracture half-length with nine fracture treatments produced the highest cumulative gas over the period of 30 years $(13,424,247,808 \mathrm{SCF})$ followed by the well design with a lateral length of $4000 \mathrm{ft}$ and $600 \mathrm{ft}$ fracture half-length with nine fracture treatments $(10,486,311,936 \mathrm{SCF})$ as shown in Table 10. Also based on this study, the fracture half-length is found to have more impact on gas production than the lateral wellbore length.

Additionally, the economic analyses based on NPV were conducted for all well designs. The results show the well designs with a horizontal lateral length of $4000 \mathrm{ft}$ and $900 \mathrm{ft}$ fracture halflength with nine fracture treatments was the most economical regardless of the gas price considered in this study. The second most economical well was the horizontal design with a lateral of $4000 \mathrm{ft}$ and $600 \mathrm{ft}$ fracture half-length with nine fracture treatments. The economic ranking of well designs remained the same when future gas prices of $\$ 4$ and $\$ 5$ were used.

Out of 28 cases studied, 17 designs had positive NPVs with $\$ 3.5 / \mathrm{MSCF}$ whereas 11 cases were determined to be uneconomical. With \$4/MSCF, 19 designs had positive NPVs while nine cases 
were determined to be uneconomical. When gas price of $\$ 5 / \mathrm{MSCF}$ is used, 24 cases had positive NPVs and four cases were determined to be uneconomical. Furthermore it is discovered that NPV values with $\$ 5.0 / \mathrm{Mscf}$ has 5 cases or designs that are economical while they were uneconomical with $\$ 4.0 / \mathrm{Mscf}$.

Based on the models designed in this study, there were no boundary effects for the duration of runs. 


\section{Chapter VII- Recommendation}

The following recommendations are presented for further study of gas production from the Utica

Shale:

To expand this study by adding alternate fractures half lengths and number of fractures.

$>$ To further expand this study with horizontal multi well field studies.

$>$ To study the impact of Stimulated Reservoir Volume (SRV) on gas production based on well designs. 


\section{Chapter VIII- Reference}

$\mathrm{He}$, Qin "Reservoir modeling and simulation of $\mathrm{CO}_{2}$ sequestration-ECBM production in unmineable coal seams." M.S. Thesis, 2011, West Virginia University.

Ikoku, Chi U., "Economic Analysis and Investment Decisions”, John Wiley \& Sons, 1985. Kaiser T., Mark., "Haynesville Shale Play Economic Analysis”, Elsevier, 2011.

Lash Gary (2008) “.Fracture and stratigraphy of the Appalachian shale and completion strategies, Society Petroleum Engineers Paper 110809, 28 p.

Nasar, Ali "A parametric study and economic evaluation of drilling patterns in deep, thick CBM reservoirs" M.S. Thesis, 2011, West Virginia University.

National Energy Technological Laboratory (http://www.netl.doe.gov/technologies/oilgas/Projects/natural-gas-project-summaries.html)

Natural Gas Watch (http://www.naturalgaswatch.org/?p=862)

Newman Donald, "Engineering economics analysis", Third Edition, 1988, Engineering Press, Inc., San Jose, CA. on pages 446-448.

Ohio Department of Natural Resources (http://www.dnr.state.oh.us/tabid/23014/default.aspx) Oil Shale Gas (http://oilshalegas.com/uticashale.html)

Pink house et. al. www.spe.org/jpt/print/archives/2010/12/10 Hydraulic.pdf

Rice University, "US-Canadian shale could neutralize Russian energy threat to Europeans", News and Media Relations 2009.

Schepers C. Karine, Reinaldo J. Gonzalez, George J. Koperna, Anne Y. Oudinot, "Reservoir Modeling in Support of Shale Gas Exploration", SPE Latin American and Caribbean Petroleum Engineering Conference, 2009.

Stevens, Paul "The 'Shale Gas Revolution': Developments and Changes". A Chatham House Report, September 2010

The Financials

(http://b2b.thefinancials.com/styles.asp?id=NatGas\&title=US\%20National\%20Average\%20Nat ural\%20Gas\%20Prices, \%20\$/MCF)

U.S. Department of Energy \& Secure Energy for America, Evaluation of Fracture Systems and Stress Fields within the Marcellus Shale and Utica Shale and Characterization of Associated 
Water-Disposal Reservoirs: Appalachian Basin, 2013 (http://www.rpsea.org/0182255/)

U.S. Energy Information Administration (http://www.eia.gov/naturalgas/weekly/\#jm-prices) 


\section{APPENDIX- Pressure Distributions}

Pressure distribution after $0,10,20$ and 30 years of production for selected wells are included in this appendix.

Pressure (psi) 2012-10-01 K layer: 1

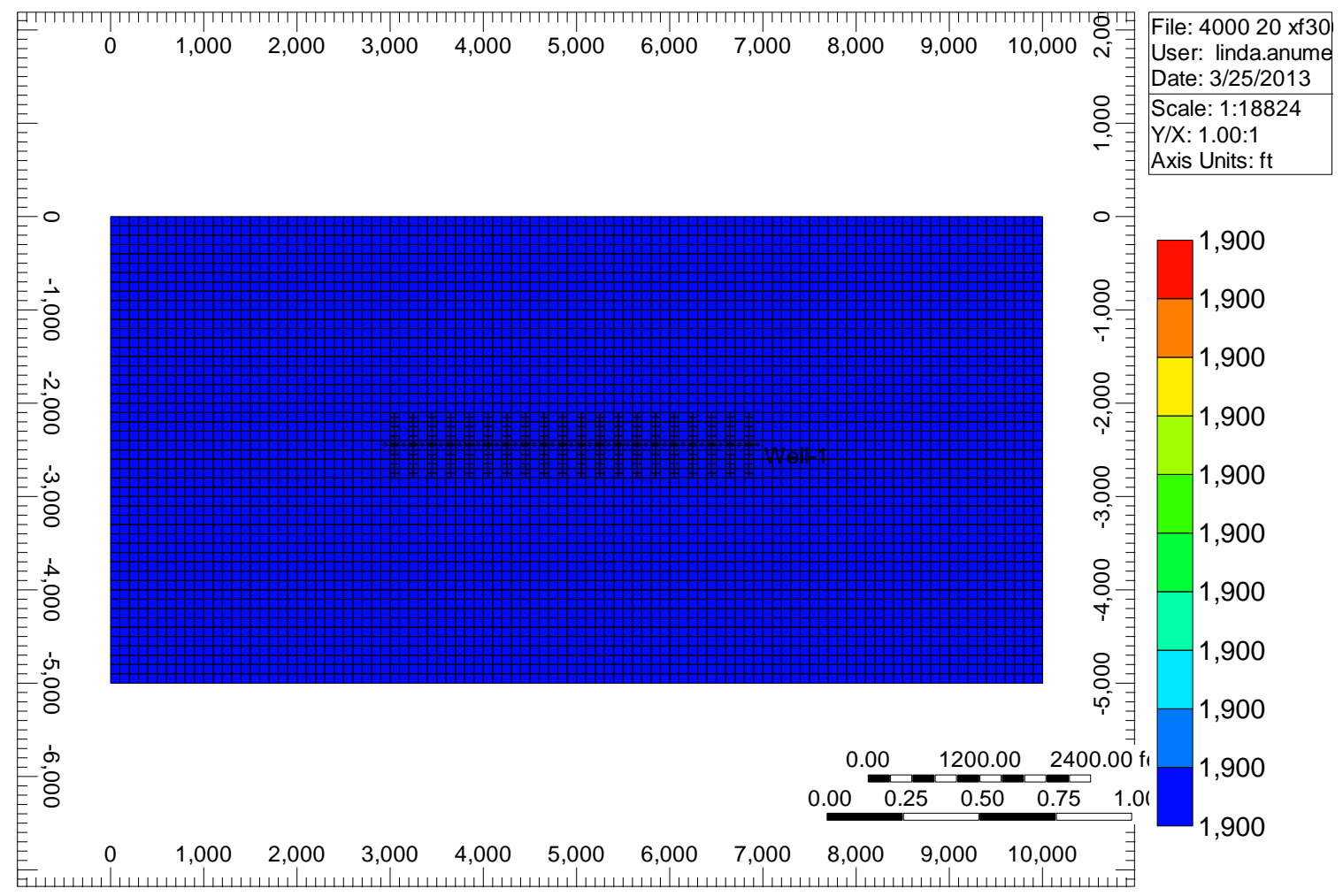

Figure Appendix 1: Initial pressure distribution for well $400020 X f 300$ 


\section{Pressure (psi) 2022-10-01 K layer: 1}

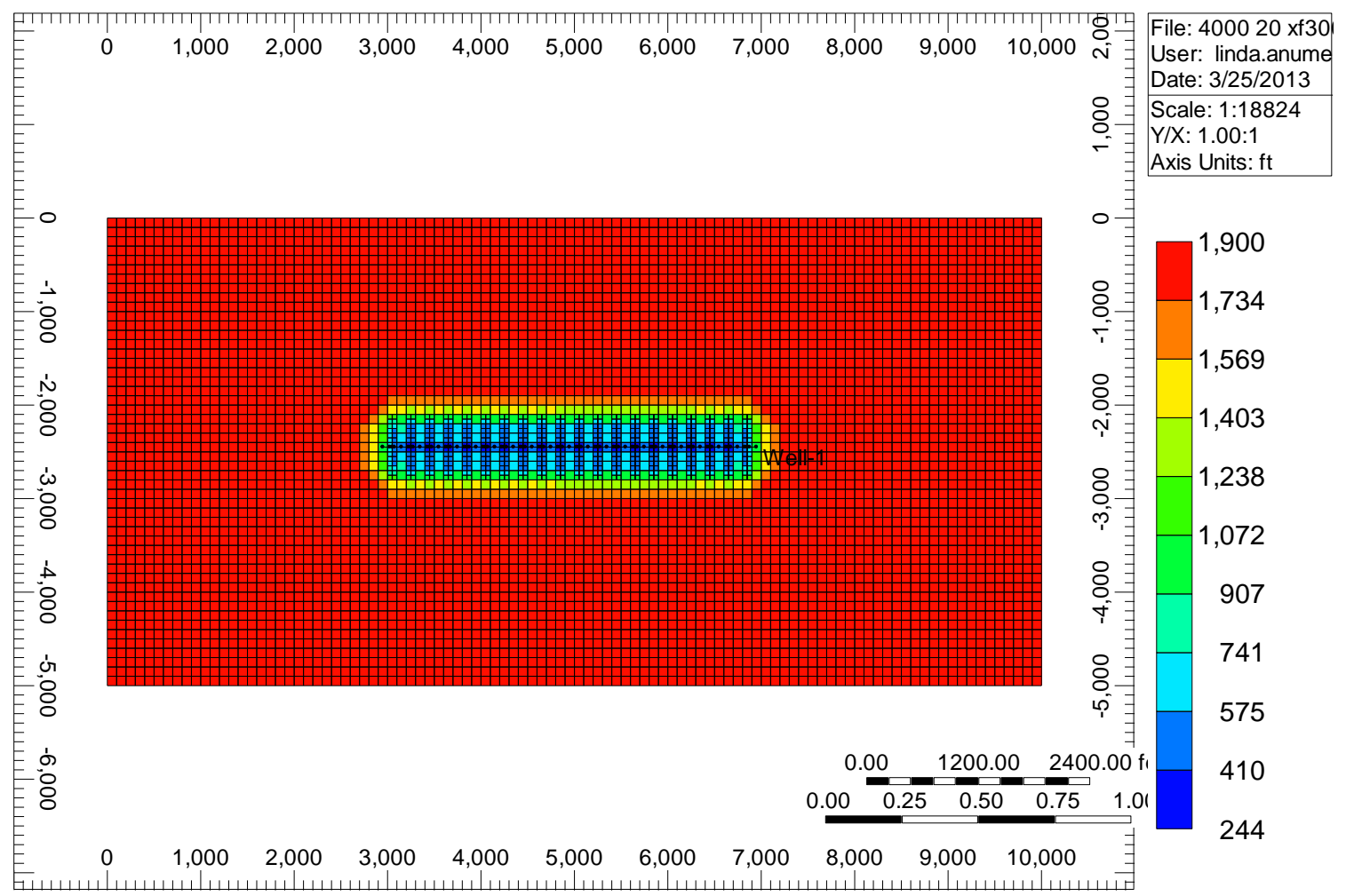

Figure Appendix 2: Pressure distribution after 10 years for well $400020 \mathrm{Xf300}$ 


\section{Pressure (psi) 2032-10-01 K layer: 1}

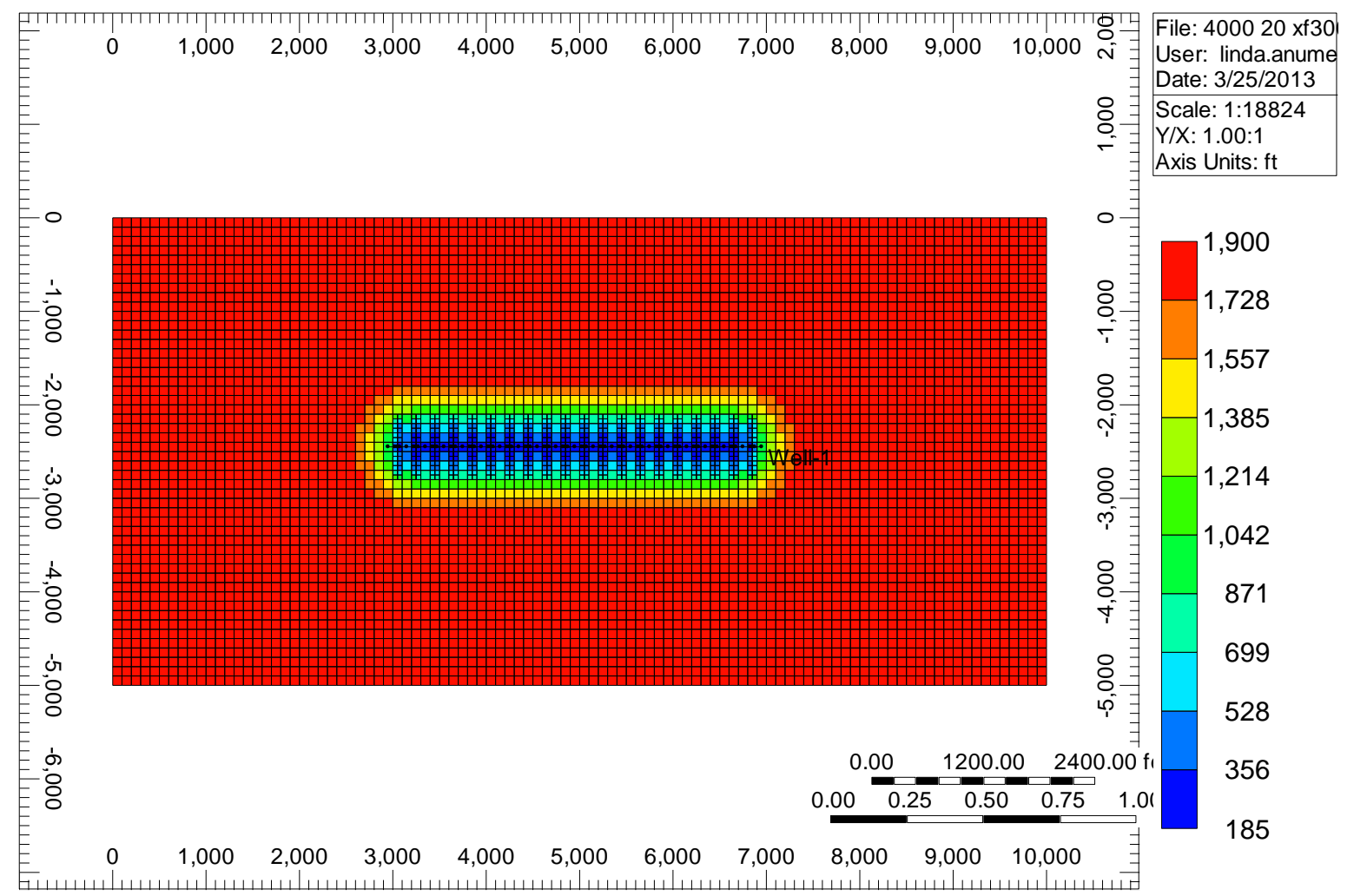

Figure Appendix 3: Pressure distribution after 20 years for well $400020 \mathrm{Xf300}$ 
Pressure (psi) 2042-10-01 K layer: 1

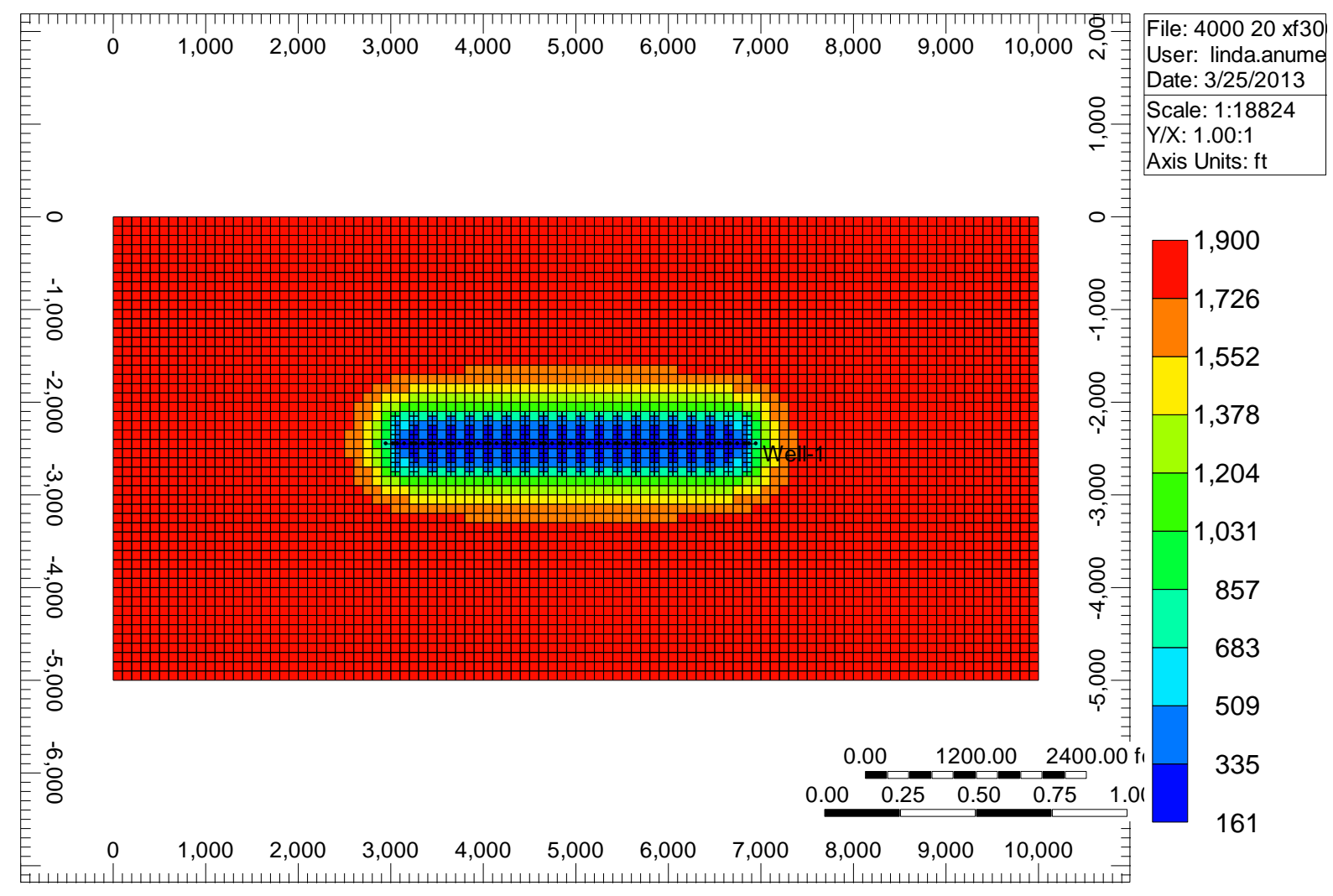

Figure Appendix 4: Pressure distribution after 30 years for well $400020 \mathrm{Xf300}$ 
Pressure (psi) 2012-10-01 K layer: 1

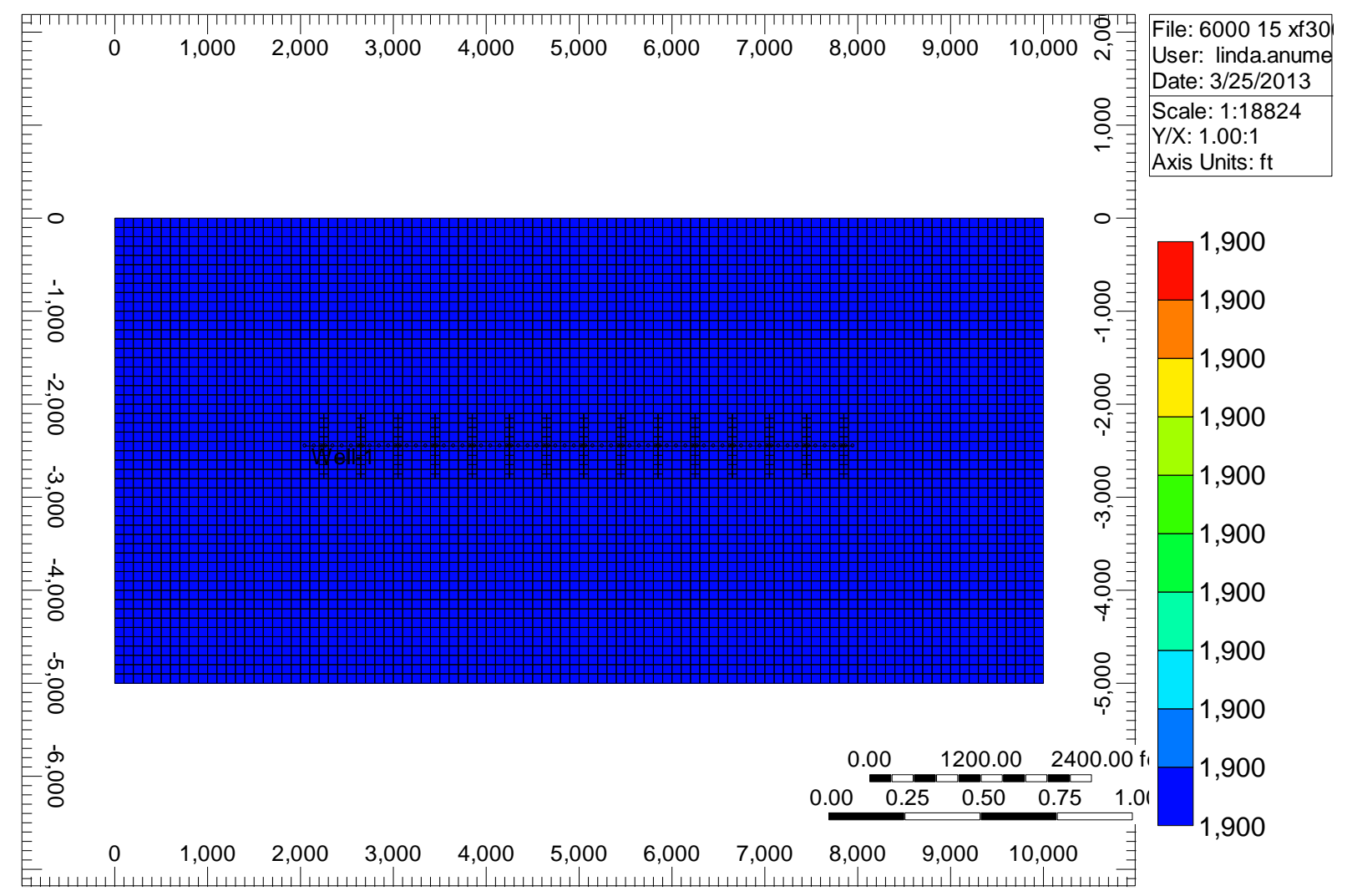

Figure Appendix 5: Initial pressure distribution for well 6000 15Xf300 
Pressure (psi) 2022-10-01 K layer: 1

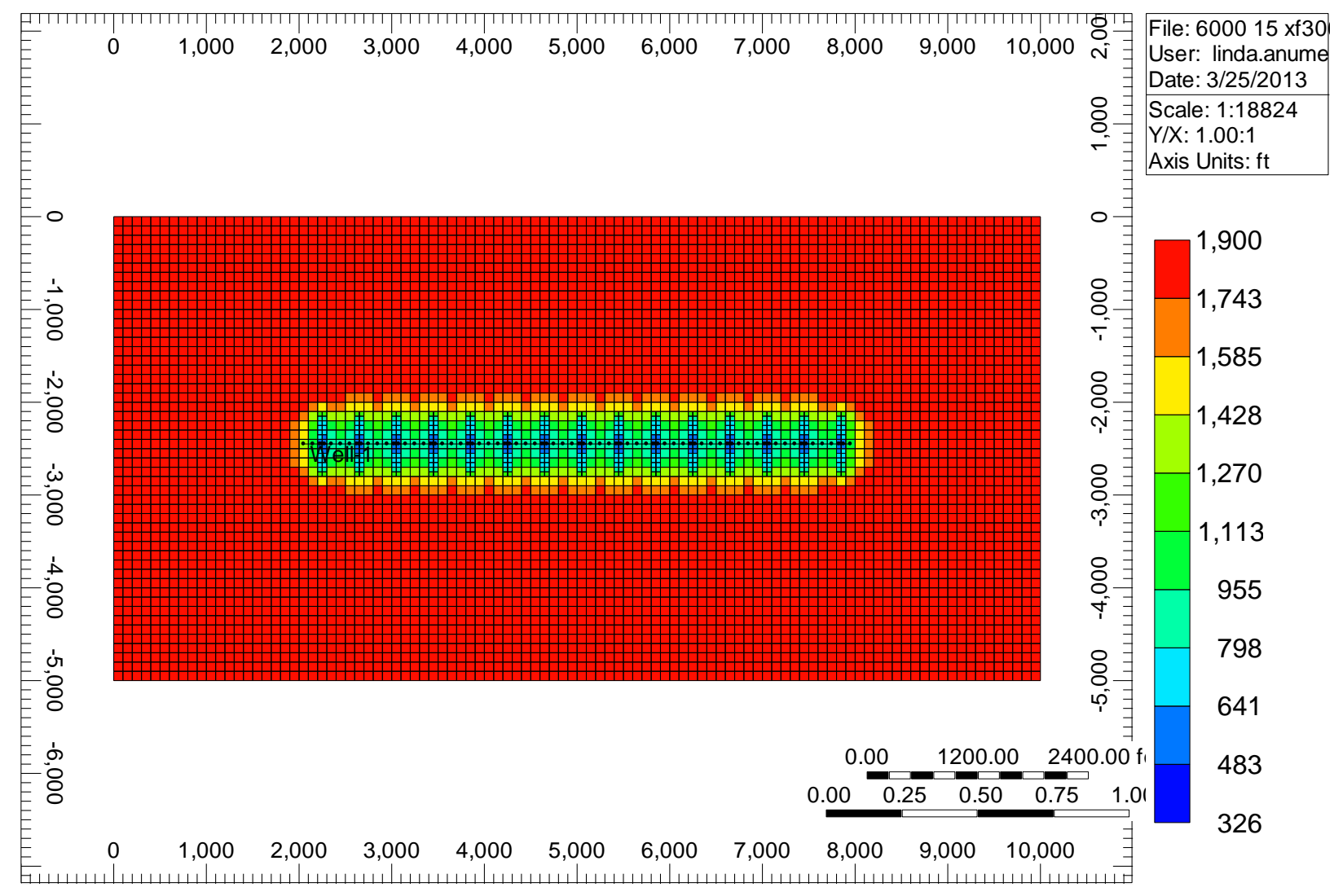

Figure Appendix 6: Pressure distribution after 10 years for well 6000 15Xf300 
Pressure (psi) 2032-10-01 K layer: 1

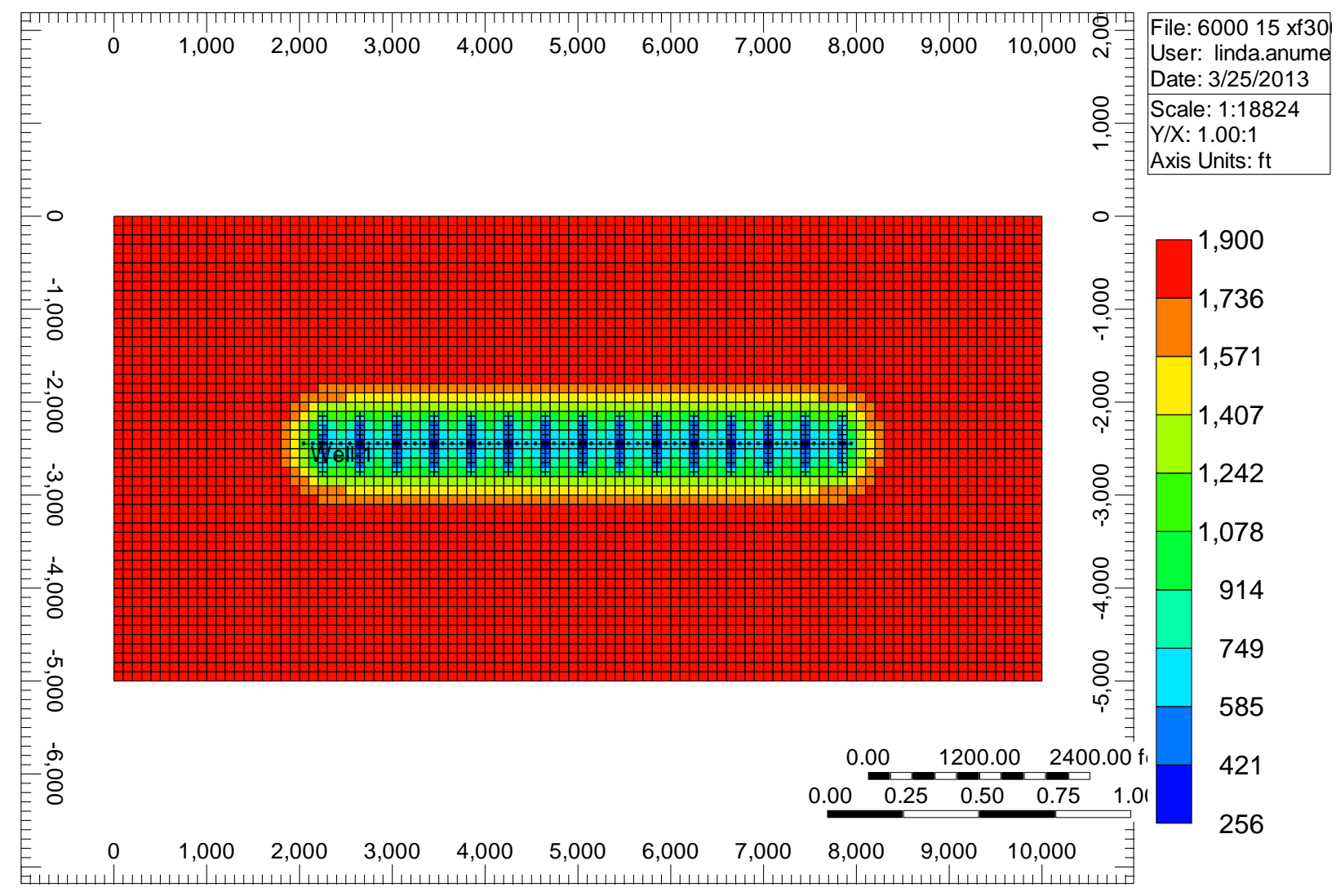

Figure Appendix 7: Pressure distribution after 20 years for well 6000 15Xf300 
Pressure (psi) 2042-10-01 K layer: 1

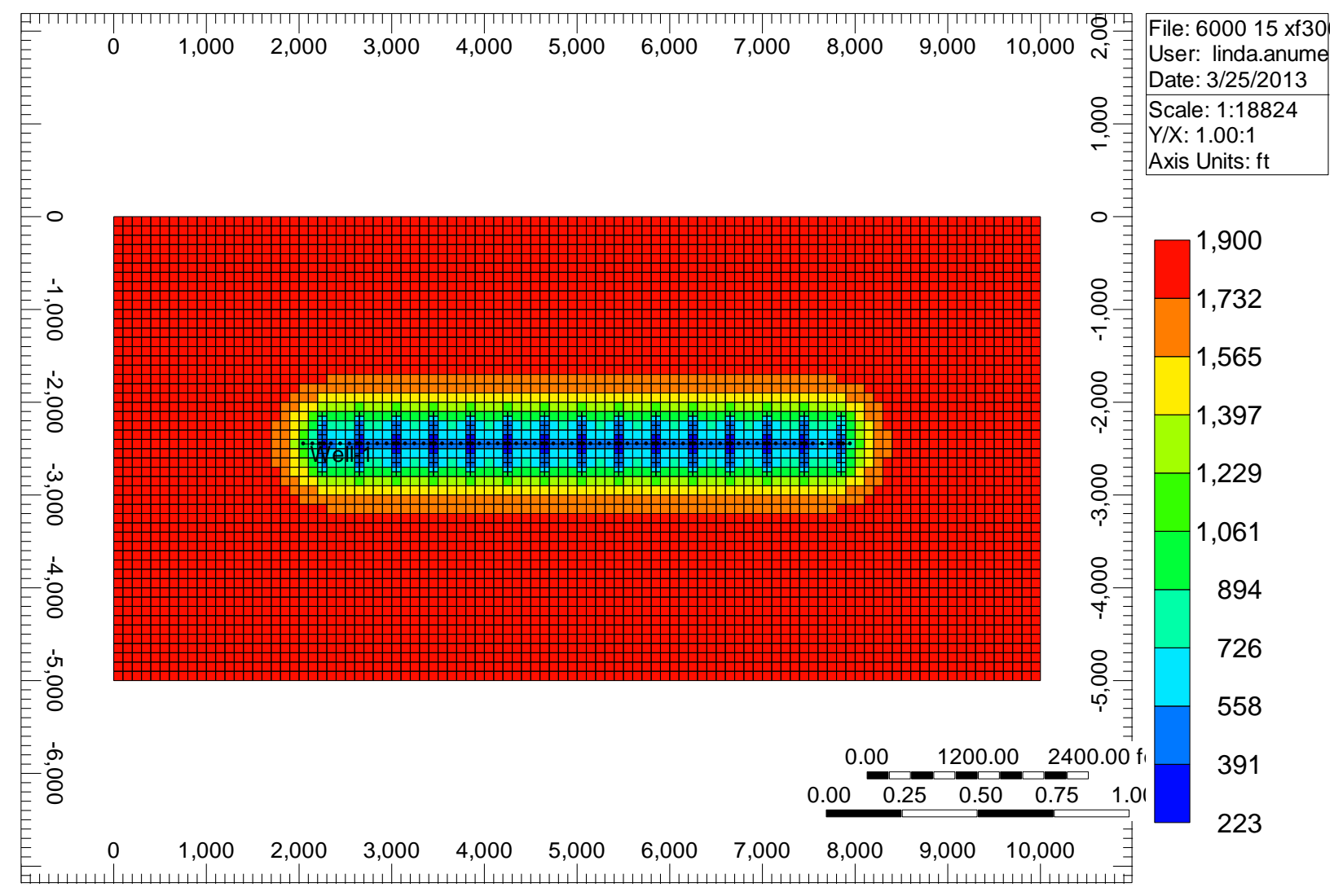

Figure Appendix 8: Pressure distribution after 30 years for well 6000 15Xf300 
Pressure (psi) 2012-10-01 K layer: 1

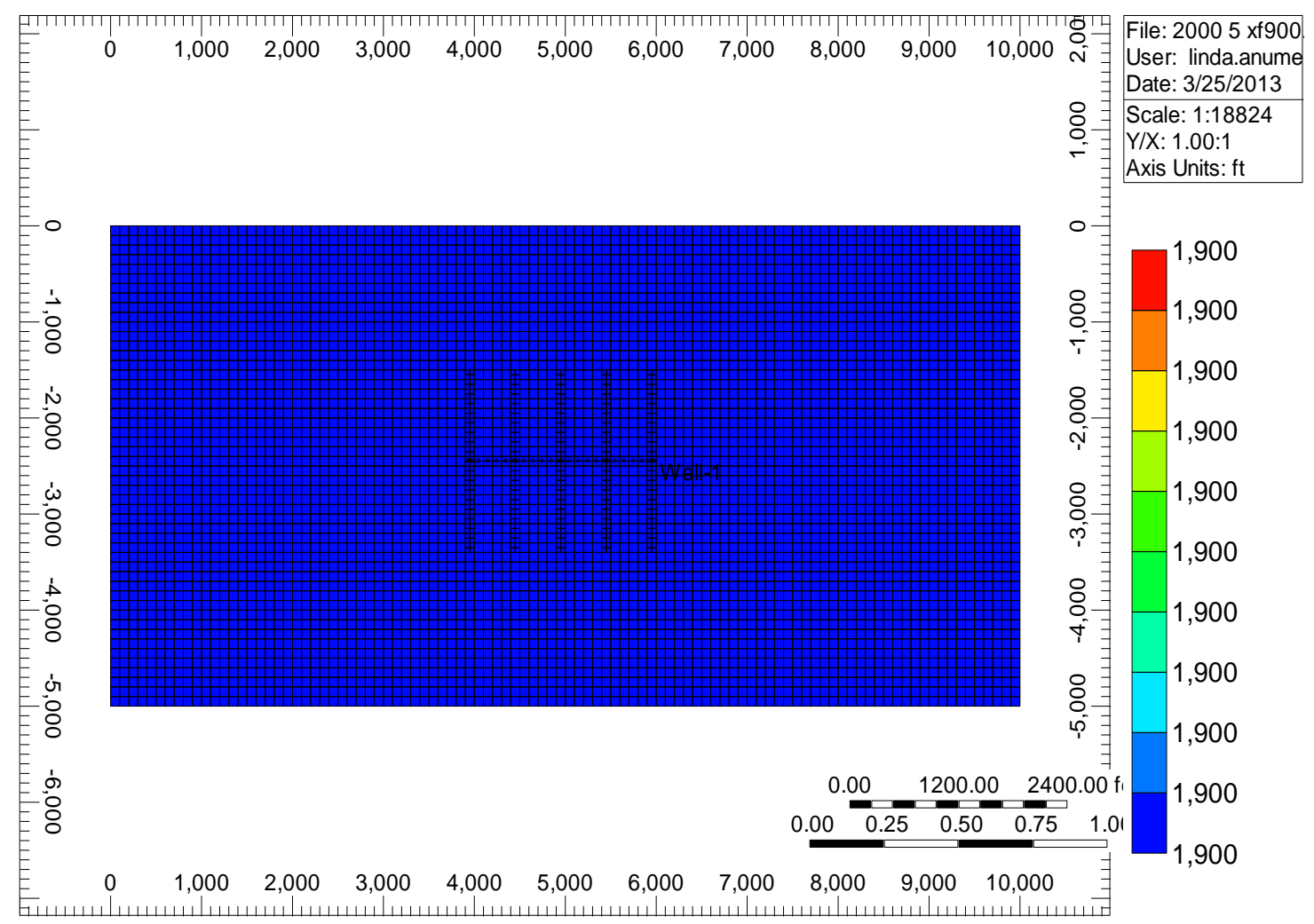

Figure Appendix 9: Initial pressure distribution for well 2000 5Xf900 


\section{Pressure (psi) 2022-10-01 K layer: 1}

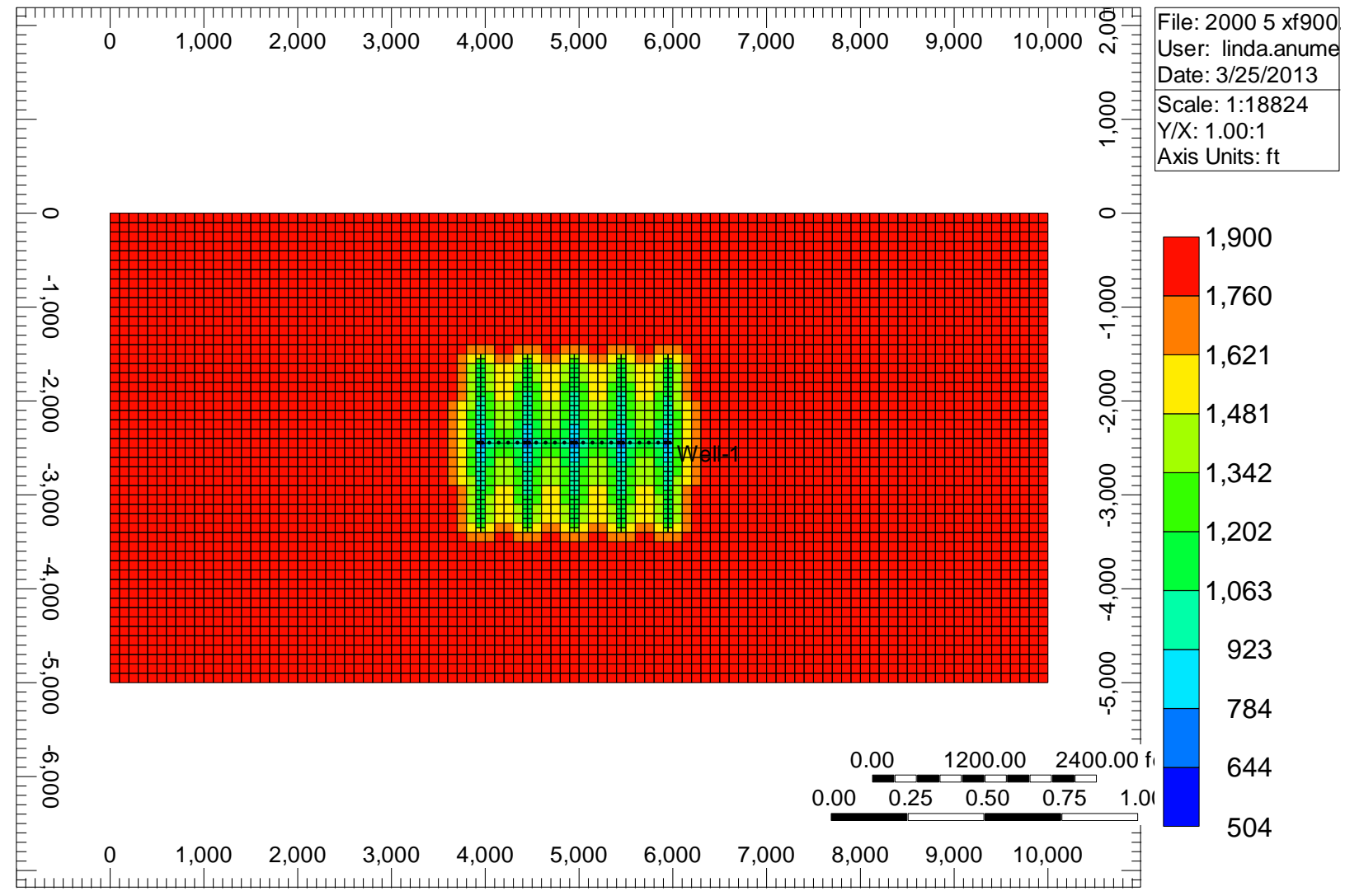

Figure Appendix 10: Pressure distribution after 10 years for well 2000 5Xf900 
Pressure (psi) 2032-10-01 K layer: 1

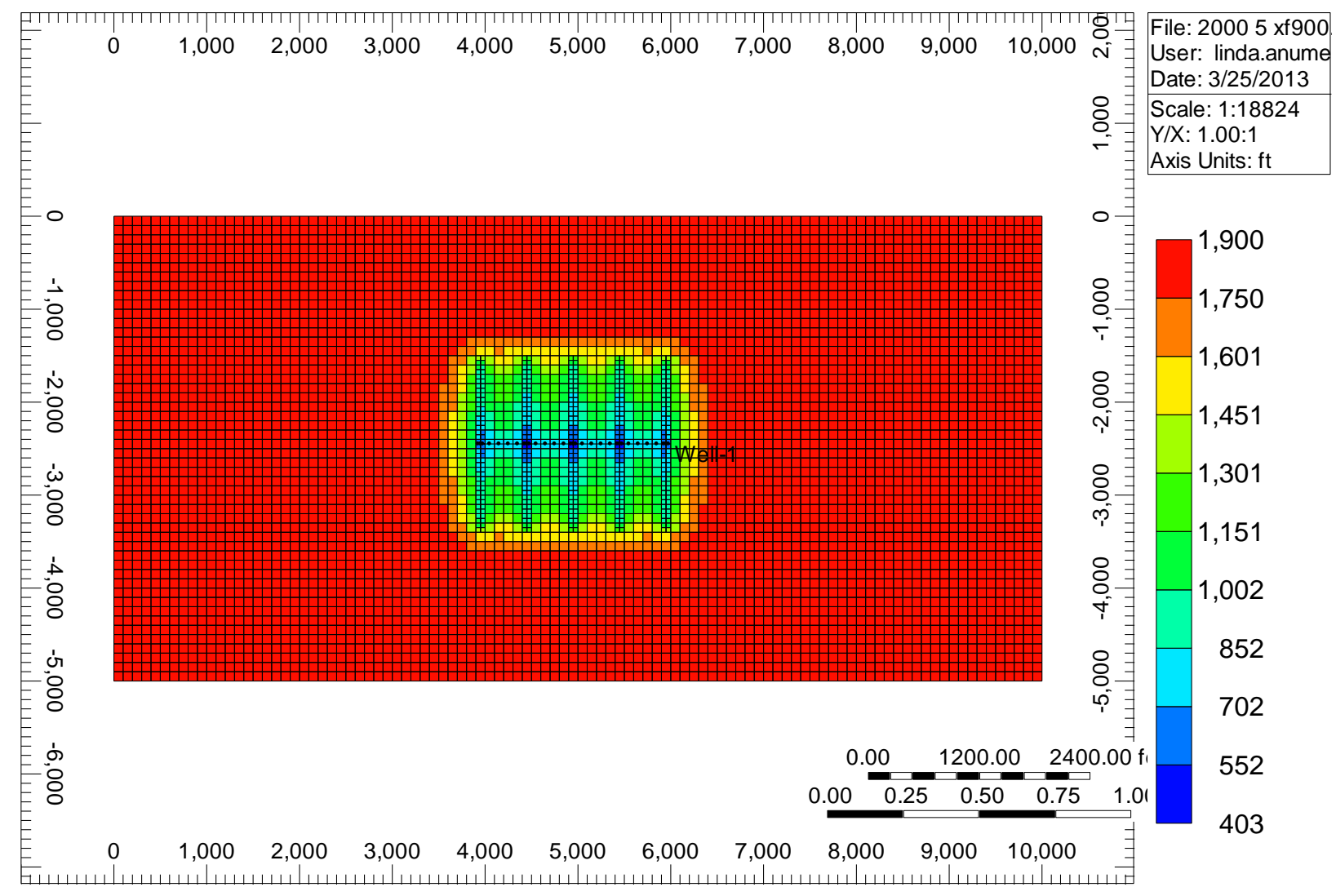

Figure Appendix 11: Pressure distribution after 20 years for well 2000 5Xf900 
Pressure (psi) 2042-10-01 K layer: 1

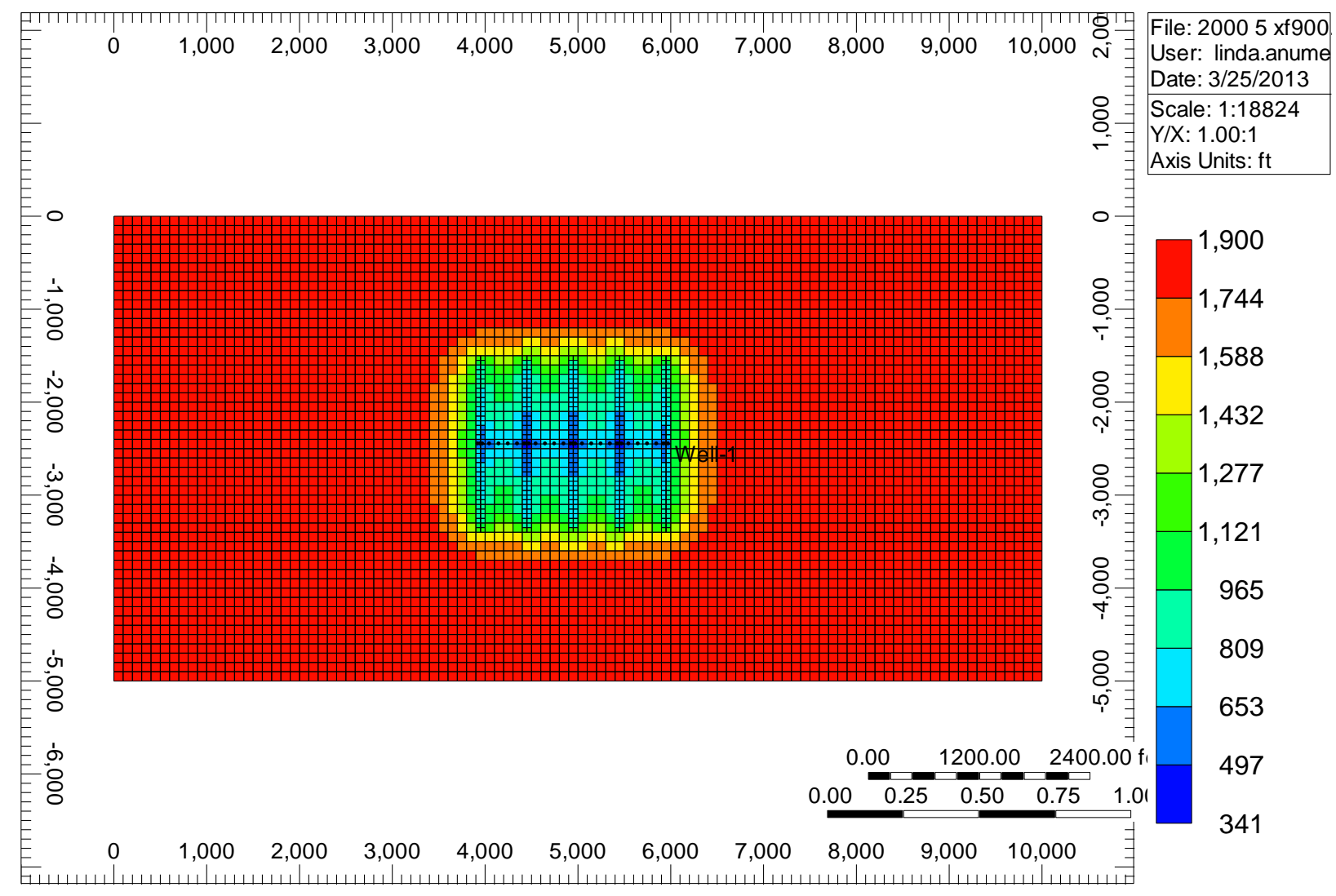

Figure Appendix 12: Pressure distribution after 30 years for well 2000 5Xf900 
Pressure (psi) 2012-10-01 K layer: 1

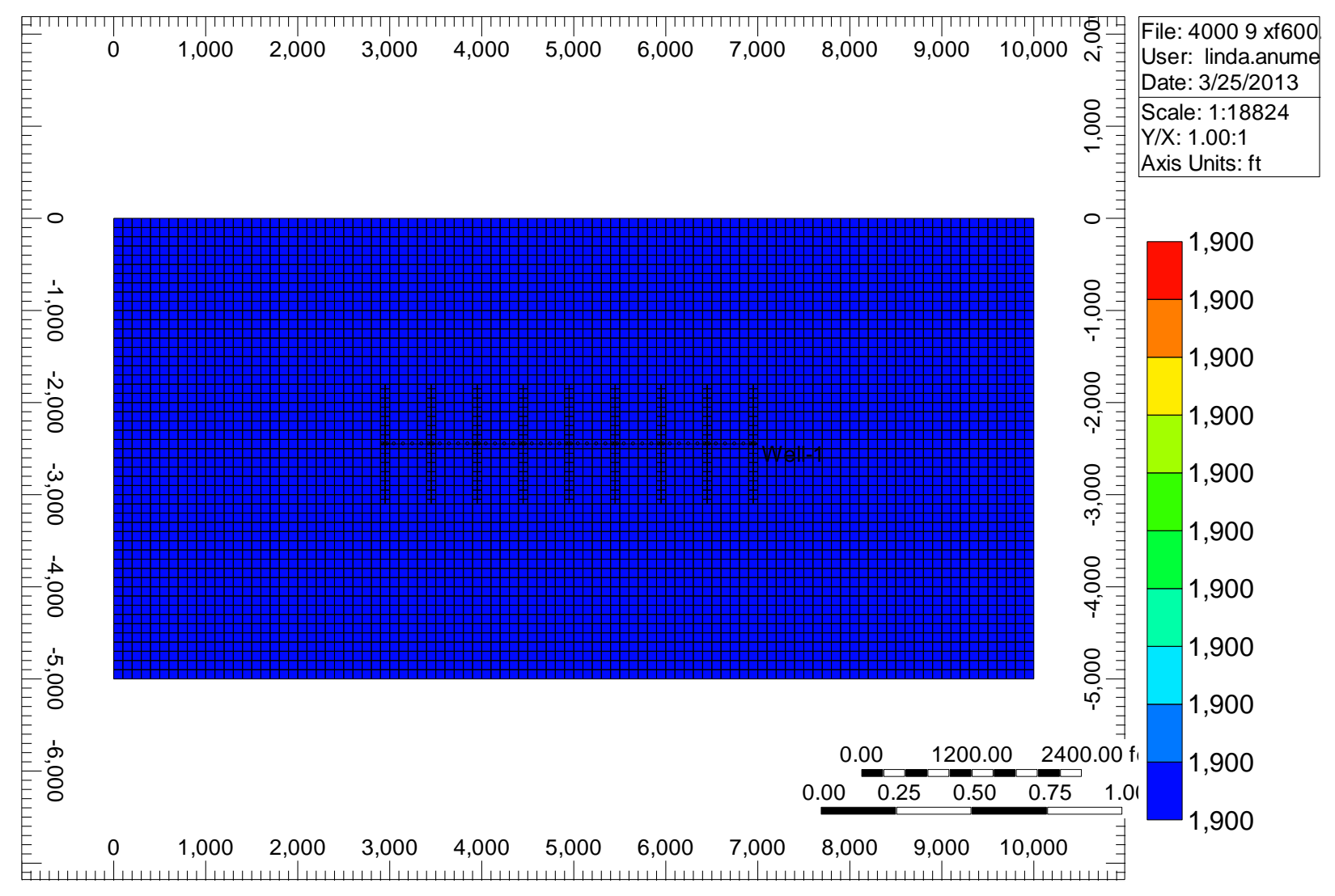

Figure Appendix 13: Initial pressure distribution for well 4000 9Xf600 
Pressure (psi) 2022-10-01 K layer: 1

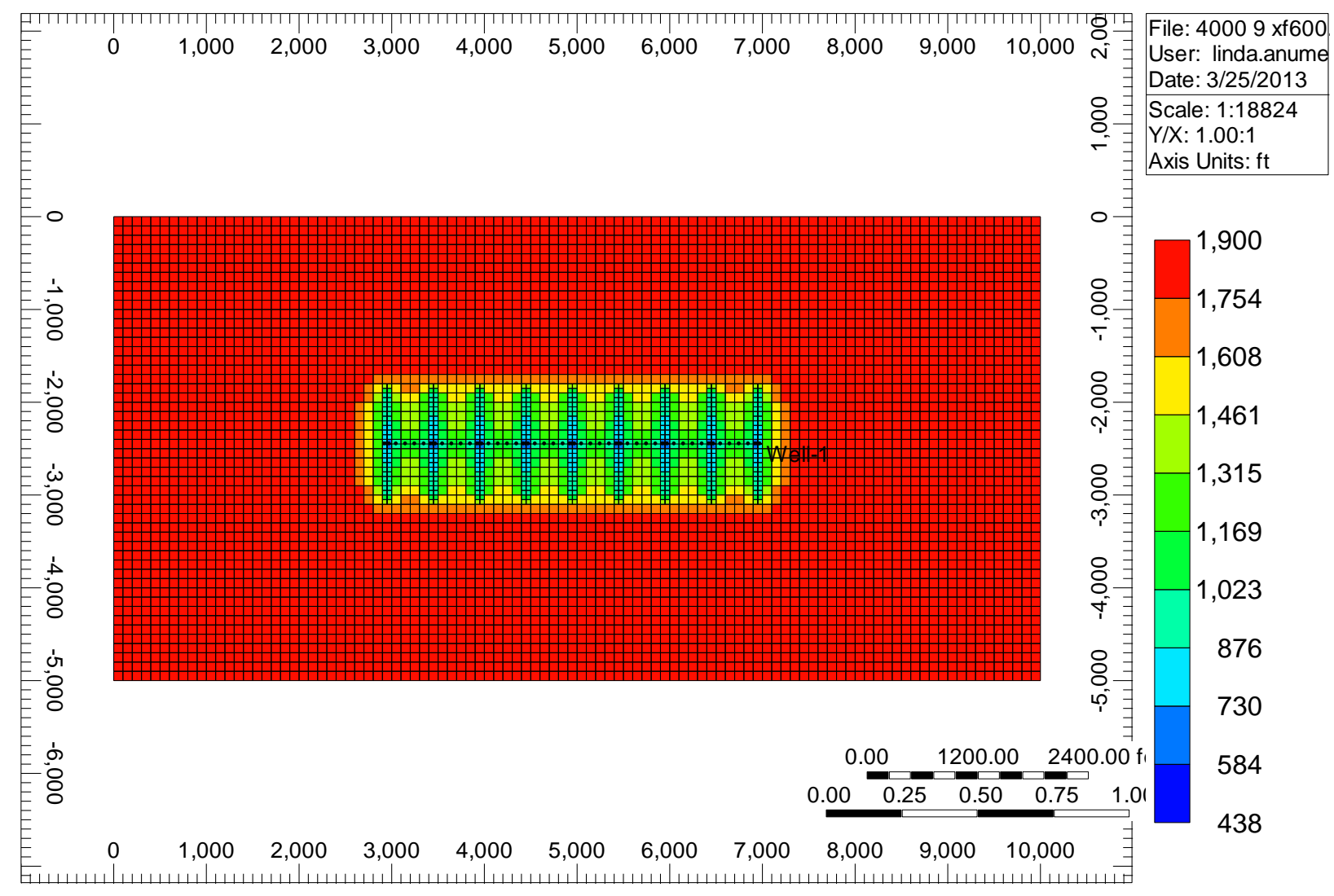

Figure Appendix 14: Pressure distribution after 10 years for well 4000 9Xf600 
Pressure (psi) 2032-10-01 K layer: 1

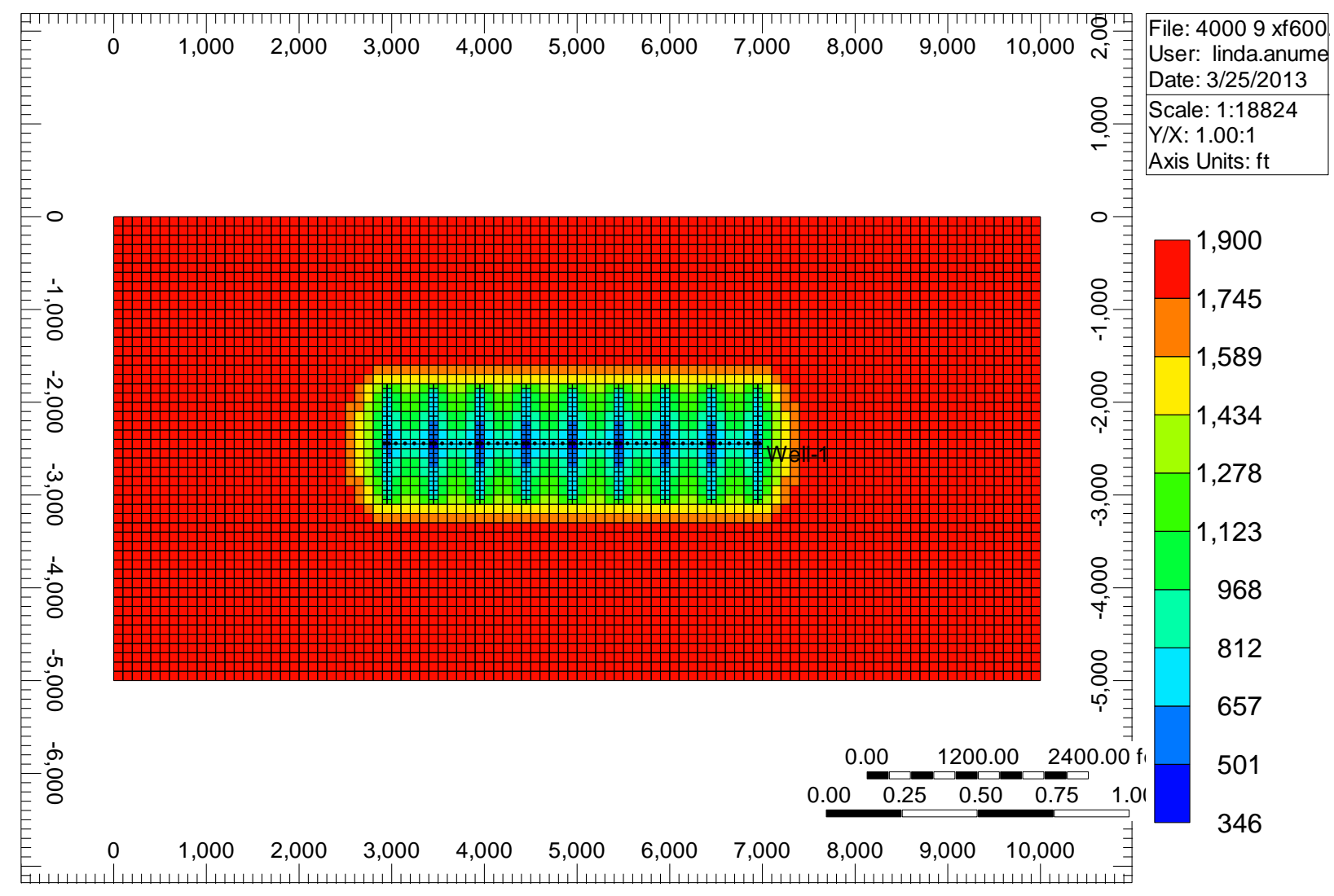

Figure Appendix 15: Pressure distribution after 20 years for well 4000 9Xf600 
Pressure (psi) 2042-10-01 K layer: 1

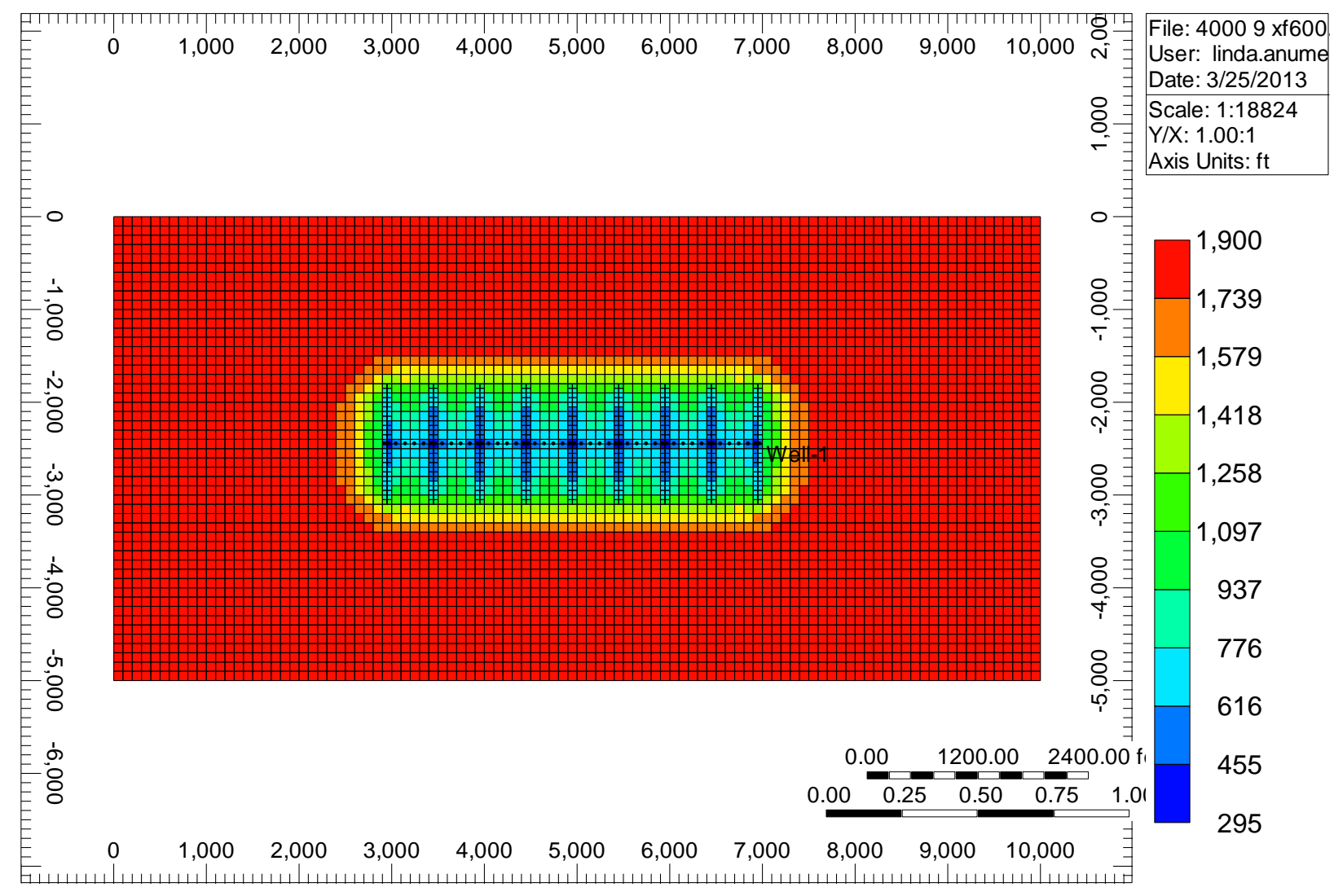

Figure Appendix 16: Pressure distribution after 30 years for well 4000 9Xf600 